Identification of the specific volatile organic compounds emitted by Anoplophora glabripennis (Moschulsky)

\author{
Dissertation \\ To attend the doctoral degree (Dr.rer.nat.) \\ of the Faculty of Forest Sciences and Forest Ecology \\ Georg-August-Universität Göttingen \\ Submitted by
}

Ramona Irina Gloria Fanny Makarow

born on the $24^{\text {th }}$ May 1987 in Munich

Göttingen, 2020 
1. Referee:

2. Referee:

Reviewer

Reviewer

Date of oral examination:

$4^{\text {th }}$ February 2020

\section{Prof. Dr. Niko Balkenhol}

Wildtierwissenschaften,

Fakultät für Forstwissenschaften und Waldökologie

Georg-August-Universität Göttingen

\section{Prof. Dr. Peter-Michael Kaul}

Physik, Statistik und Messtechnik,

Fachbereich angewandte Naturwissenschaften

Hochschule Bonn-Rhein-Sieg

\section{Prof. Dr. Wolfgang Rohe}

Fakultät Ressourcenmanagement

Hochschule für angewandte Wissenschaft und Kunst

Fachhochschule Hildesheim/Holzminden/Göttingen

\section{Prof. Dr. Andreas Schuldt}

Waldnaturschutz/Forest Nature Conservation

Georg-August-Universität Göttingen 


\section{TABLE OF CONTENTS}

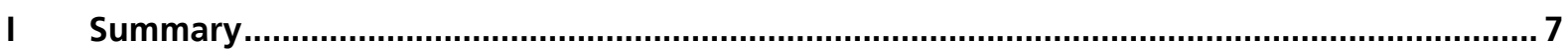

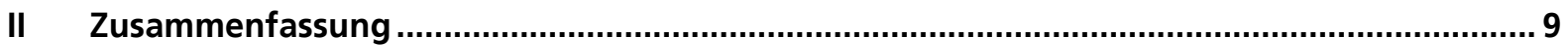

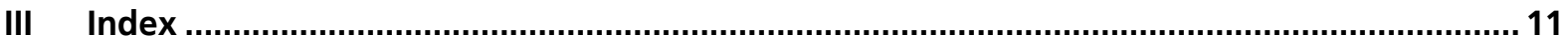

$1 \quad$ Introduction

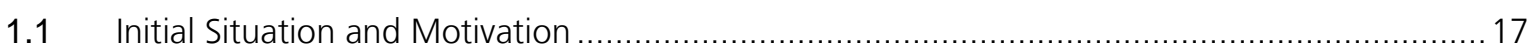

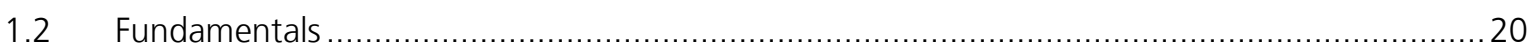

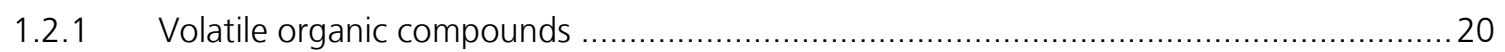

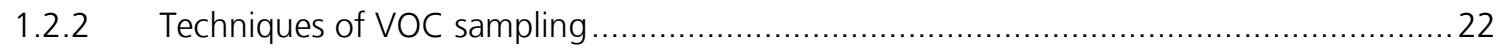

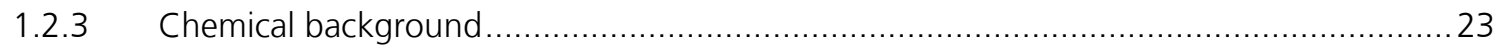

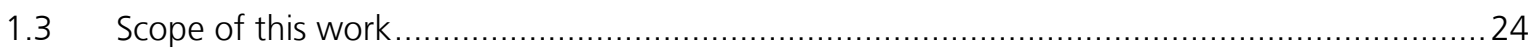

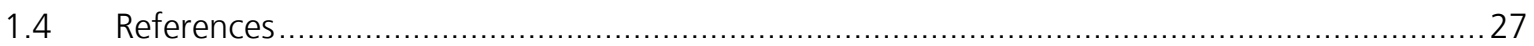

2 Part I: Investigation of volatile organic compounds emitted by Anoplophora glabripennis (Moschulsky) by using thermal desorption and gas chromatography-mass spectrometry ...........34

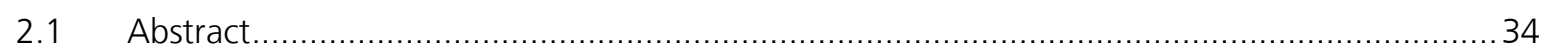

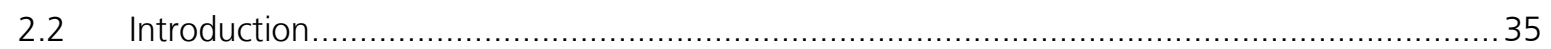

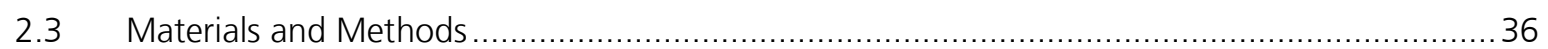

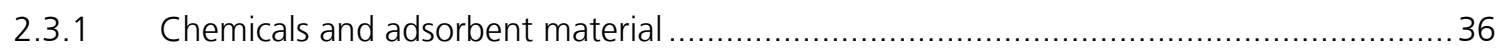

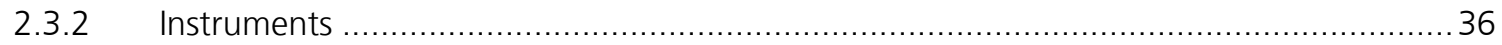

2.3.3 Analytical Method Development and sampling optimisation ….................................. 37

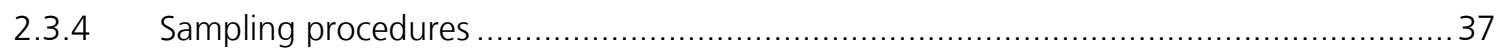

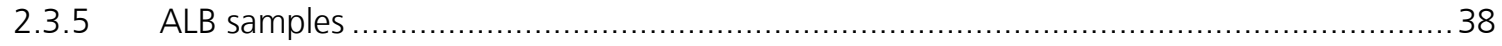

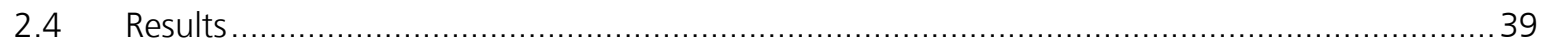

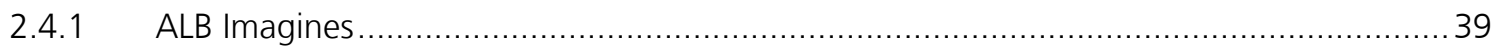

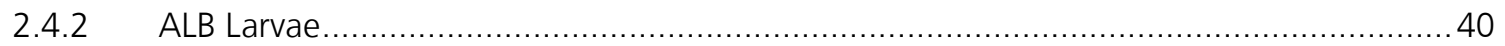

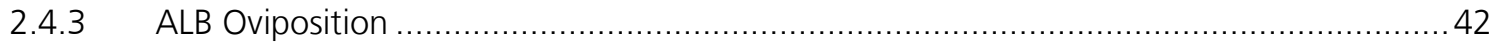

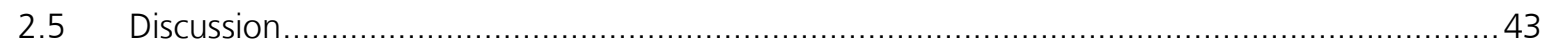

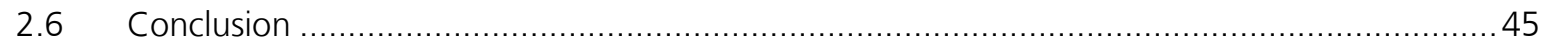

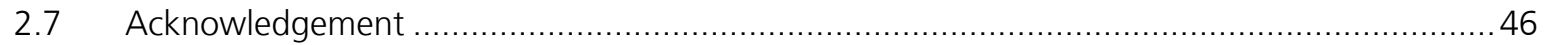

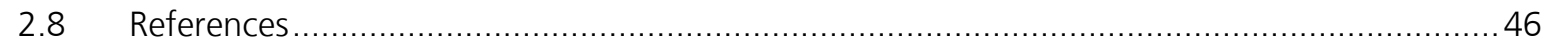

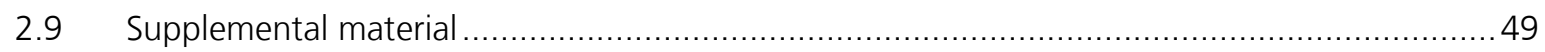

3 Part II: Identification of Anoplophora glabripennis (Moschulsky) by its emitted specific

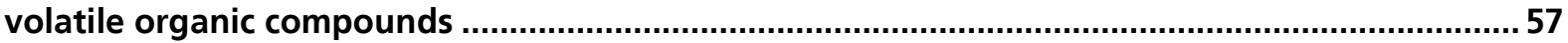




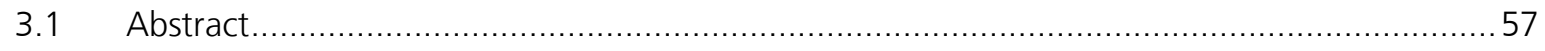

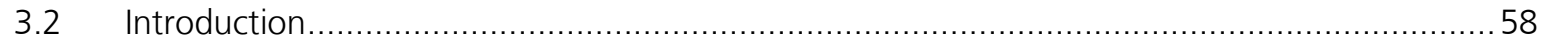

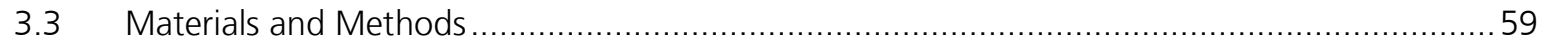

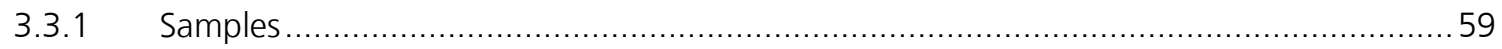

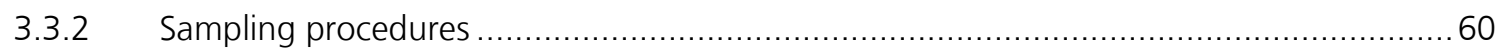

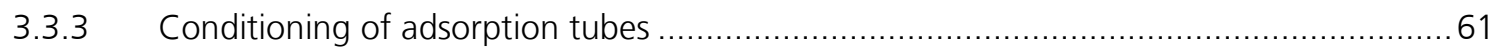

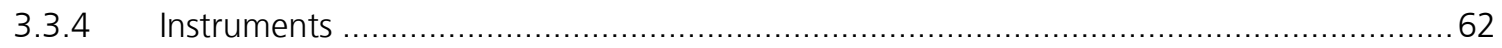

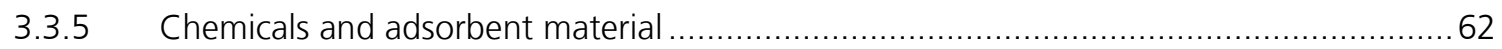

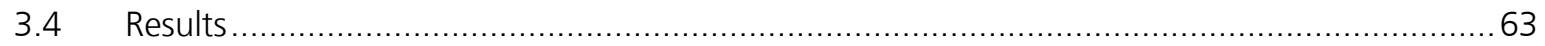

3.4.1 Comparison of ALB- infested Acer (by larvae and by ovipositions) and non-ALB stressed Acer

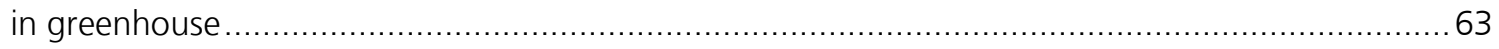

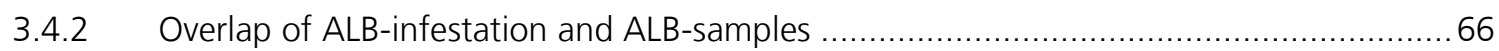

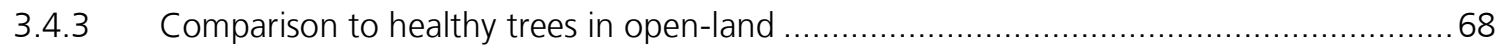

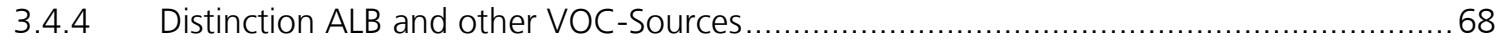

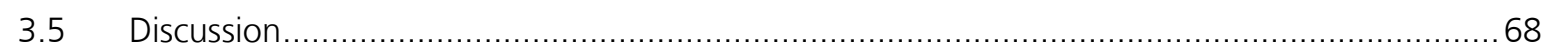

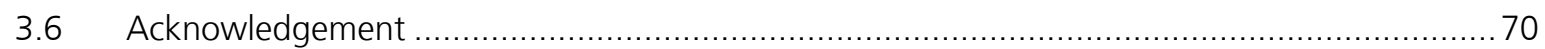

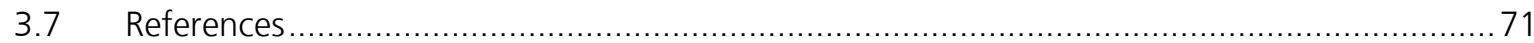

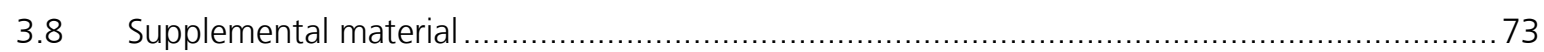

4 Part III: Behördliche Anforderungen an ALB-Spürhunde-ein Erfahrungsbericht...................77

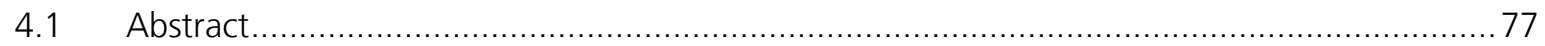

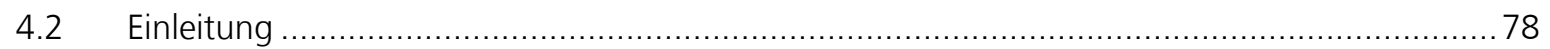

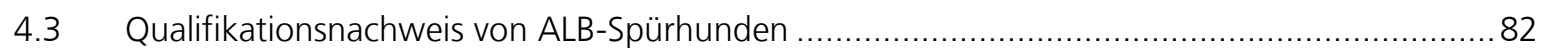

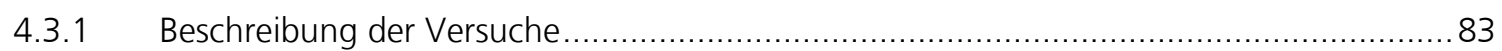

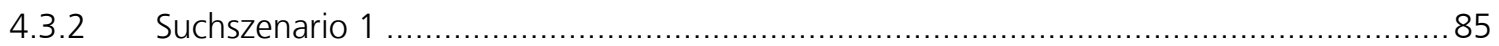

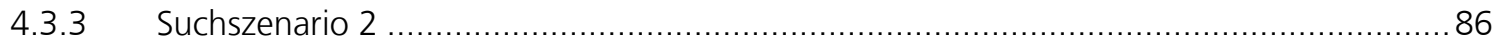

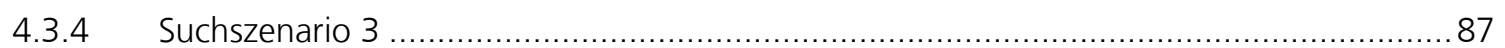

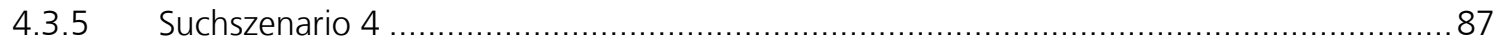

4.4 Fazit zu den ersten Versuchen eines Qualifikationsnachweises für ALB-Spürhunde ................88

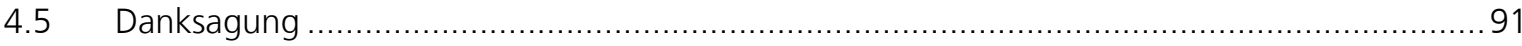

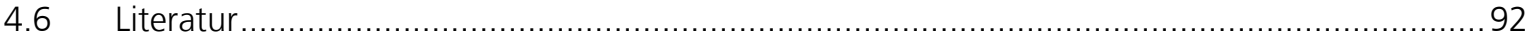

5 Discussion 


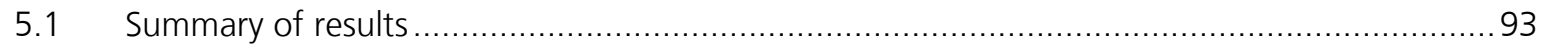

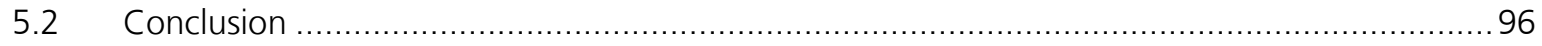

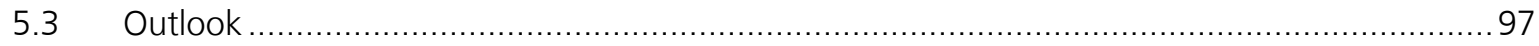

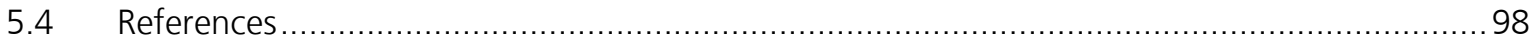

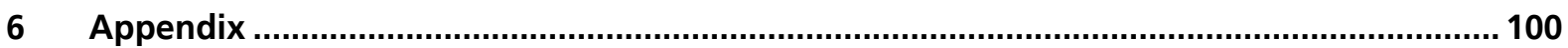

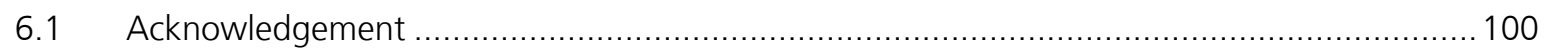

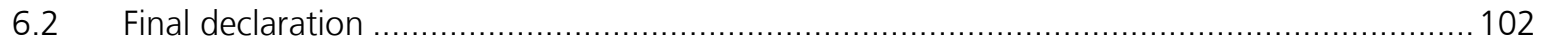




\section{Summary}

The globalisation and the increasing international trade have raised the number and risk of introduction of foreign species and invasive pests for years. Although native species have adapted to the native habitat over many years and generations, invasive intruders often possess characteristics that are superior to native species. Thus, and because of a lack of natural enemies, they bear the potential of decimation or complete displacement of the native species; furthermore, the introduction of pathogens or nematodes as a vector possesses a high damage potential.

The available measures of the local plant protection services to combat invasive species are confined. They are limited to the felling of infested trees or plants and regular controls within the infested area. A spread of single infestations can thereby be prevented, but undetected infestations can unimpededly spread, which points out the main challenge: the detection of the species. This concerns the infestation in open land as well as the single animal on its path of introduction. Concerning the development of new adequate detection systems for invasive species, there is only little research activity going on. For other fields like detection of explosives or narcotics, the research activities date back for more than one decade and consequently there are detection systems available, which are, for example, used for explosive detection in airports. The detection principle bases on the chemistry of these substances. When adapting the development steps for a detector of invasive species, the first step (i) is the investigation of the chemical substances emitted by the species of interest. Beyond that, for living organisms it is relevant to investigate (ii) if their chemical signature is specific and if a distinction to native organisms is possible. This dissertation focusses in these two major issues on the example of Anoplophora glabripennis (Moschulsky) (Asian longhorned beetle, ALB).

In part I the chemical substances emitted by Anoplophora glabripennis in different development stages (imago, larva, oviposition) were investigated. The focus of the investigation was on the volatile organic compounds (VOCs), which are available in the gas phase for a detector. They were analysed qualitatively by thermal desorption coupled with gas chromatography and a mass selective detector. Altogether 229 substances were identified: 34 from larvae, 19 from imagines and 176 from ovipositions. Ovipositions of two generations were analysed, both over an 8-week period with focus on ageing and repeatability. (+)- $\alpha$-Longipinene occurred in $100 \%,(+)$-cyclosativene and $\alpha$-cubebene in $99 \%$ of all oviposition measurements. The monoterpene ocimene occurred from ovipositions in a later development stage. 2,4-Dimethyl-1-heptene and (+)-cyclosativene were detectable in all three ALB sample types.

With the objective of distinction to native insect species, in part II some native insect species were analysed, which often lead to mistaken identification of species by visual determination. Overlap between ALB and native insect species were identified for Saperda carcharias Pupa and Cossus cossus larva for 2,4dimethyl-1-heptene. No overlap for sesquiterpenes were identified. Beside native insect species, in part II other VOC sources that determine the chemical background of ALB's habitat were investigated: healthy, 
not infested host trees in open land and stressed trees, whereas the stress originates from mechanical damage and poor water and light supply. The infestation of a tree also leads to stress as there is a damage in the tree's internal channels of supply with the consequence of a lack of supply. Generally, stress leads to a change in the VOC pattern of trees. To ensure that the VOCs determined from ALB infested trees originate from the ALB infestation and not from general stress, the mechanically stressed trees were also analysed.

Altogether 169 substances were identified. 11 substances occur from ALB infested or mechanically damaged trees, but not from healthy trees. (+)-Cyclosativene, $(+)-\alpha$-longipinene, copaene and caryophyllene are detectable only from ALB-infested Acer not from mechanically damaged or healthy Acer; however, these substances are also emitted by healthy Salix and thus bear the potential of mistaken identification.

2,4-Dimethyl-1-heptene is among all tree samples exclusively present in the ambience of ALB-infested trees. It is rarely detectable from native insect species' samples. As a result, the expansion of the ALB VOC pattern to (+)-cyclosativene, (+)- $\alpha$-longipinene, copaene and 2,4-diemthyl-2-heptene and the monoterpene 3-carene and ocimene can be interpreted as an ALB-specific VOC pattern.

In order to verify this pattern, in part III some experiments were carried out with sniffer dogs. At present sniffer dogs are the only available detectors for ALB. They are commonly conditioned with biologic ALB samples and trained to indicate ALB-infested material. On the basis of this assumption differently setted experiments were carried out with a synthetic ALB mixture consisting of standards of the substances $(+)$-cyclosativene, $(+)-\alpha$-longipinene, caryophyllene and ocimene. The use of copaene was not possible, because standards for these sesquiterpenes were not available at all. The mixture was applied on a developed scent carrier. In different experiments different sniffer dog teams confirm the recognition of the ALB-mixture as ALB-characteristic.

In summary, the method of extracting specific VOC patterns could be a promising strategy to prevent an aggravation of the invasive species' problem. With the method more invasive pests like Agrilus planipennis or the genus Monochamus, the vector of the nematode Bursaphelenchus xylophilus can be analysed and their specific VOC pattern added to ALB pattern. For invasive pests of the same species as ALB e.g. Anoplophora chinensis, it is likely that the VOC emission is similar with identical specific VOCs. The extraction of specific VOCs from further invasive pests combined with the VOC pattern of Anoplophora would cover relevant and threatening pests from this decay in Europe and Northern America. The development, approval and implementation of suitable detectors for import controls would be the next step to contribute to the protection of Europe's biodiversity and forest habitats on the basis of these results. 


\section{Zusammenfassung}

Die Globalisierung und der zunehmende internationale Handel erhöhen seit Jahren die Zahl und das Risiko der Einschleppungen von gebietsfremden Arten und Schadensorganismen. Obwohl die Anpassung der heimischen Arten über viele Jahre und Generationen an das heimische Habitat stattgefunden hat, bringen Neueindringlinge häufig Eigenschaften mit sich, die der ursprünglichen Art überlegen sind. Sie haben dadurch das Potenzial zur Dezimierung oder vollständigen Verdrängung der heimischen Art. Auch die Einschleppung von Krankheiten oder Nematoden birgt großes Schadpotenzial.

Die Maßnahmen, die den örtlichen Pflanzenschutzdiensten zur Bekämpfung invasiver Arten zur Verfügung stehen sind limitiert. Sie beschränken sich im Grunde auf die Fällung von befallenen Bäumen oder Pflanzen und die regelmäßige Kontrolle von Befallsgebieten. Eine Ausbreitung von einzelnen Befallsherden kann auf diese Weise zwar verhindert werden, unentdeckte Befallsgebiete hingegen, können sich ungestört ausweiten. Das Aufspüren stellt das Hauptproblem dar bei der Vermeidung der Ausbreitung von invasiven Arten: Das betrifft sowohl den Befall im Freiland, der in der Regel zufällig durch aufmerksame Mitbürger entdeckt wird, als auch das Aufspüren einzelner Tiere auf Ihrem Einschleppweg. Auf dem Gebiet der invasiven Arten gibt es nur wenig Forschung, die sich mit der Entwicklung von adäquaten Detektoren befasst. Für andere Gebiete wie Explosivstoffe oder Betäubungsmittel reicht die Forschung schon mehr als eine Dekade zurück und entsprechend gibt es heute Detektoren, die beispielsweise an Flughäfen zum Aufspüren von Sprengstoffen Verwendung finden. Das zugrundeliegende Detektorprinzip richtet sich auf die Chemie der Stoffe. Überträgt man den Pfad der Detektorentwicklung auf invasive Arten, steht an erster Stelle (i) die Aufklärung der chemischen Substanzen, die vom Zielobjekt emittiert wird. Darüber hinaus stellt sich bei Lebewesen die Frage, ob ihre chemische Signatur (ii) spezifisch ist und eine Abgrenzung zu anderen, einheimischen Arten möglich ist. Diese Dissertation näherte sich diesen beiden Fragestellungen am Beispiel des Insekts Anoplophora glabripennis (Moschulsky) (Asiatischer Laubholzbockkäfer, kurz: ALB).

In Kapitel 1 werden die chemischen Substanzen qualifiziert, die durch Anoplophora glabripennis in seinen Entwicklungsstadien (Imago, Adult, Oviposition) emittiert werden. Vor dem Hinblick der Entwicklung von Detektionsmöglichkeiten steht die Qualifizierung von volatilen, organischen Substanzen im Fokus. Unter Verwendung eines geeigneten Adsorbens können dies Volatile angereichert werden. Die Analyse erfolgt mittels Gaschromatographie/Massenspektrometrie gekoppelt mit einem Thermodesoptions Einlasssystem (TD-GC/MS). Insgesamt werden 229 Substanzen identifiziert, von denen 34 von ALB-Larven, 19 von adulten Tieren und 176 von Eiablagen stammen. Eiablagen werden in zwei Generation und jeweils in mehrmaliger Wiederholung gemessen. Als Schnittmenge aus beiden Generationen werden 24 Substanzen nachgewiesen. (+)- $\alpha$-Longipinene tritt dabei in $100 \%,(+)$-Cyclosativene und $\alpha$-Cubebene in $99 \%$ aller Eiablage Messungen auf. Das Monoterpen Ocimene tritt in einem späteren Entwicklungsstadium der Eiablage auf. Zwei Substanzen treten bei allen ALB Probentypen auf: 2,4-Dimethyl-1-heptene und (+)-Cyclosativene. 
Mit dem Ziel der Abgrenzung zu einheimischen Arten, werden in Kapitel 2 einheimische Insektenarten hinsichtlich ihrer VOC-Emissionen untersucht, die besonders bei der visuellen Bestimmung von ALB häufig zu Verwechslungen führen. Überschneidungen zu ALB werden im Falle von Saperda carcharias Puppe und Cossus cossus Larve für 2,4-Dimethyl-1-heptene festgestellt. Die Gruppe der Sesquiterpene bleibt von Überschneidungen zu einheimischen Arten unberührt. Neben den einheimischen Arten werden in Kapitel 2 auch andere VOC-Quellen, die im Lebensraum von ALB den chemischen Hintergrund ausmachen, untersucht. Dazu zählen gesunde Wirtsäume im Freiland ebenso wie gestresste Bäume, deren Stress durch mechanischen Schaden und schlechte Wasser- und Lichtversorgung hervorgerufen wird. Der Befall eines Baumes durch ALB führt zu Stress beim Baum, da durch die Larven ein Schaden in den Versorgungswegen entsteht und die Versorgung des Baumes gestört ist. Stress im Allgemeinen führt zu einer veränderten VOC-Signatur von Bäumen. Um nun auszuschließen, dass gestresste Bäume für das VOC-Muster verantwortlich sind, werden diese ebenfalls untersucht. Insgesamt werden 169 Substanzen identifiziert, wovon 11 Substanzen bei mechanisch geschädigten Bäumen auftreten, nicht jedoch bei gesunden Wirtsbäumen. (+)-Cyclosativene, (+)- $\alpha$-Longipinene, Copaene und Caryophyllene kann alleinig auf ALB-Befall zurückgeführt werden, da diese Substanzen nur bei ALB-befallenen Acer auftraten, nicht aber bei mechanisch geschädigten Acer. Jedoch traten diese Stoffe auch bei gesunden Bäumen der Gattung Salix auf und bergen somit das Potenzial von Verwechslung. 2,4-Dimethyl-1-hepten tritt bei ALB-befallenen Bäumen auf und vereinzelt bei Analysen einheimischer Arten. Folglich führt eine Erweiterung des ALB-Musters von (+)-Cyclosativene, (+)- $\alpha$-Longipinene, Copaene um die Substanzen 2,4-Dimethyl-1-heptene und das Monoterpen 3-Carene oder Ocimene zu einem spezifischen ALB-VOC-Muster.

Für die Verifizierung des ALB-VOC-Musters werden in Kapitel 3 mit ALB-Spürhunden Experimente durchgeführt. Einzig ALB-Spürhunde werden derzeit zur Detektion von ALB eingesetzt. Sie werden mit biologischem ALB-Material konditioniert und erlernen ALB befallenes Material anzuzeigen. Mit dieser Annahme wird eine synthetische ALB-Mischung aus Standards der Substanzen (+)-Cyclosativene, (+)- $\alpha$-Longipinene, Caryophyllene und Ocimene hergestellt und auf dafür entwickelten Geruchsträgern aufgebracht und den Spürhunden auf unterschiedlichen Versuchsstrecken angeboten. Die Substanz Copaen kann der Mischung nicht beigefügt werden, da alle Bestrebungen Standards dieser Substanz zu erwerben erfolglos bleiben. In verschiedenen Experimenten bestätigen verschiedene Spürhundeteams die Wiedererkennung der Geruchsstoffe als ALB-typisch.

Insgesamt kann die Extraktion spezifischer VOC-Muster eine vielversprechende Strategie sein, um eine Verschärfung des Problems der Einschleppung invasiver Schadorganismen zu verhindern. Die Methode kann auch auf andere in Europa bereits problematische Arten wie Agrilus planipennis oder Monochamus, den Vektor der Nematode Bursaphelenchus xylophilus, übertragen werden. Die Kombination der verschiedenen VOC-Muster kann dann genutzt werden, um entweder bereits vorhandene Detektoren-wie Spürhunde oder instrumentelle Analytik-einzusetzen oder neue zu entwickeln. Die Implementierung von Detektoren für Importkontrollen wäre der nächste Schritt, um zum Schutz der heimischen Biodiversität auf Grundlage dieser Ergebnisse beizutragen. 


\section{Index}

\section{III.I List of tables}

Table 1: Potentially invasive or invasive beetles published by the Bundesamt für Naturschutz (Scheibner et al. 2015).

Table 2: Host trees of ALB according to the implementing decision 2015/893 (European Union) 18

Table 3: Some compound examples from urban, rural and forest air

Table 4: Overview of the analysed ALB samples, the correlating enrichment method and the number of replicates 38

Table 5: List of substances determined from a TD-GC/MS analysis from ALB imagines: one male beetle ('A') and one female beetle ('B'). Substances are sorted by class (HC hydrocarbons, MT monoterpenes, ST sesquiterpenes) and rate ('total no. of 13') 39

Table 6: List of substances determined from TD-GC/MS analysis from three ALB larvae ('A', 'B', 'C'). Substances are sorted by class (HC hydrocarbons, Benz benzoic substances, MT monoterpenes, ST sesquiterpenes) and rate ('no. of 22')

Table 7: List of substances from TD-GC/MS analysis from ALB ovipositions that occur in both generations. Substances are sorted by class (HC hydrocarbons, Benz benzenes, MT monoterpenes, ST sesquiterpenes) and rate ('total of 86'). 86 measurements were obtained.

Table 8: List of substances that occur in at least 50 \% of each batch 'Beetle', 'Larva' and 'Oviposition', whereas the latter is subdivided in the two generations and both generations as a sum

Table 9: List of substances determined for oviposition of first generation ALB (2015) sorted by substance class (row 2; HC hydrocarbons, Benz benzoic substances, MT monoterpenes, ST sesquiterpenes) and rate in total of 27 measurements (row 'total no. of 27 ') and relative (row 'rel., \%') 50

Table 10: List of substances determined for oviposition of second generation ALB (2016) sorted by substance class (row 2: HC hydrocarbons, Benz benzoic substances, MT monoterpenes, SP sesquiterpenes) and rate in total of 59 measurements (row 'total no. of 59') and relative (row 'rel., \%') 53

Table 11: Overview of the analysed samples, the environment of analysis and the sampling procedure including enrichment parameters.

Table 12: Results from the analysis carried out under greenhouse circumstances with "ALB infested Acer": substances detected from ALB infested Acer (43 measurements); "ALB ovipositions on Acer": results from Makarow et al. and "stressed Acer" : substances detected from Acer stressed by insufficient water and light supply and cut off branches. Substances are sorted by class with HC hydrocarbons, MT monoterpenes, ST sesquiterpenes and Benz benzoic substances. 65 
Table 13: List of substances determined from a TD-GC/MS analysis from ALB-infested Acer. Only substances that occur in at least $20 \%$ of all measurements are shown. The substances are sorted by class and rate. The numbering in the first column is according to the complete substance-list, which can be seen in the supplemental materials. The substances are sorted by class (HC hydrocarbons, MT monoterpens, ST sesquiterpenes, Benz benzoic substances) and rate ('total no. of 43 ').

Table 14: List of substances that occur in at least $50 \%$ of one of the ALB-batches in comparison to other possible VOC sources. The numbers indicate the occurrence of the substance in each sample batch in percentage. Starred data originates from Makarow et al. (Makarow et al. 2019). .70

Table 15: List of substances determined from a TD-GC/MS analysis from healthy Acer, Populus and Salix. Substances are sorted by class (HC hydrocarbons, Benz benzoic substances, MT monoterpenes, ST sesquiterpenes) and rate ('total no. of 27 '). .74

Table 16: List of substances determined from a TD-GC/MS analysis from non-ALB stressed Acer. Substances are sorted by class (HC hydrocarbons, Benz benzoic substances, MT monoterpenes, ST sesquiterpenes) and rate ('total no. of $\left.22^{\prime}\right)$....... .75

Table 17: List of substances determined from a TD-GC/MS analysis from native insects species. Substances are sorted by class (HC hydrocarbons, Benz benzoic substances, MT monoterpenes, ST sesquiterpenes) and rate ('total no. of $\left.42^{\prime}\right)$... .76

Table 18: Overview of the most relevant VOCs emitted by different ALB sample types (ST: sesquiterpene, HC: hydrocarbons, MT: monoterpenes). The numbers indicate the occurrence of the substance in each sample batch in percentage. 94 


\section{III.II List of Figures}

Figure 1: Imagines of Agrilus planipennis (E. Jende, Eppo website), Anoplophora glabripennis (R.Makarow) and Harmonia axyridis (M. Maspero, Eppo website) (EPPO Global Database 2013; Eppo)

Figure 2: Frequency distribution of the relative molecular mass (MM) of 320 odorants. Intervals include the lower mass and exclude the higher mass. The figure below shows correspondingly the minimal and maximal amount of C-atoms (Legrum 2011).

Figure 3: Different headspace sampling techniques

Figure 4: Schema of the sampling procedure for the comparison of the trapping efficiency of Tenax® TA, Tenax $®$ GR and Carbotrap $®$. The vital larva was put into a $20 \mathrm{ml}$ headspace-vial closed with an aluminium cap with septum. Two tubes were inserted through the septum.

Figure 5: Overlay of chromatograms: in black, blue and red trunk with ALB ovipositions on Acer, in green healthy trunk of Salix

Figure 6: Overlay of chromatograms: in black, blue and red trunk with ALB oviposition on Acer, in green healthy trunk of Acer. 55

Figure 7: Overlay of chromatograms: in black, blue and red trunk with ALB oviposition on Acer, in green healthy trunk of Populus.

Figure 8: scheme of extracting the specific volatile organic compounds emitted from Anoplophora glabripennis including the analysis carried out by Makarow et al.(Makarow et al. 2019). The green arrow indicates the overlap of substances to the substances detected from standalone ALB samples. The red arrows indicate that no overlap of substances of healthy trees as well as of native insect species is requested.

Figure 9: sampling procedure on a tree trunk. The analysed part is wrapped in Nalophan foil, closed with staples and tension belts.

Figure 10: Sampling procedure for beetles, pupae and frass. The samples are stored in the headspace vial while sampling with the pump

Figure 11: Anoplophora glabripennis Käfer. .78

Figure 12: Quarantänezone in Bayern [Quelle: LFL] 79

Figure 13: Bekämpfungsmaßnahmen bei ALB-Befall in Bayern [Quelle: Frank Nüßer, LFL] ..... .80

Figure 14: Spürhunde der Lf Lim Einsatz an verschiedenen Gebieten [Quelle: Frank Nüßer, LFL] .81

Figure 15: Gelände der LfL mit vier realisierten Suchszenarien 83

Figure 16: Suchszenario 1, wobei das rote x die verschiedenen Auslageorte des ALB befallenen Holzstückes markiert. .85 
Figure 17: Suchszenario 2, wobei das untere rote $x$, die Lage des unbekannten ALB befallenen Holzstückes markiert und das obere eine bekannte ALB Probe zur positiven Bestätigung der Hunde nach Bedarf ....... 86 Figure 18: Geruchsträger (mitte) und zwei Anreicherungsverfahren für die Geruchsträger: vom befallenen Baum (links) und von einer Larve (rechts)

Figure 19: Suchszenario 3 mit insgesamt 3 ALB Proben (2 unbekannte und eine zur positiven Bestätigung nach Bedarf) 87

Figure 20: Suchszenario 4 mit synthetischer ALB Geruchsmischung 88 


\section{III.III List of Abbreviations}

${ }^{\circ} \mathrm{C}$. degree Celsius

$\mu \mathrm{m}$ micrometre

ALB Anoplophora glabripennis

Benz benzoic substances

CAS Chemical Abstracts Service

CIS Cold Injection System

$\mathrm{cm}$. centimetre, centimetre

EU European Union

$\mathrm{eV}$ electron volt

GC gas chromatography

h hour

ha. hectare

H-BRS Hochschule Bonn-Rhein-Sieg

$\mathrm{HC}$. hydrocarbons

IPPC International Plant Protection Convention

ISPM International Standard for Phytosanitary Measures $\mathrm{km}$ kilometre

$\mathrm{kPa}$ kilopascal

$\mathrm{LfL}$. Bayrische Landesanstalt für Landwirtschaft, Landesanstalt für Landwirtschaft

$\mathrm{m}$ metre $\mathrm{mg}$ milligramme, milligramme

$\min$. minute $\mathrm{ml}$. millilitre

MS mass spectrometry MT monoterpens NIST National Institute of Standards and Technology ppb parts per billion ppbv parts per billion by volume PPS plant protection service

ppt parts per trillion pptv parts per trillion by volume psi pounds per square inch PTR-ToF Proton-Transfer Reaction ionization -Time-of-Flight mass spectrometry QZ Quarantänezone SBSE Stir bar sorption extraction SPE solid phase extraction 
TD thermal desorption

TD-GC/MS thermal desorption gas chromatography-mass spectrometry TDU thermal desorption unit u unified atomic mass unit

VOC volatile organic compound VVOC. very volatile organic compounds 


\section{Introduction}

\subsection{Initial Situation And Motivation}

During the last years the number of alien species has constantly increased (Scheibner et al. 2015). In 2015 the Bundesamt für Naturschutz (Germany) published a list of 168 alien plant and animal species that are potentially problematic for nature protection. Some alien species do not have any impact on the native flora and fauna, some have no destructive impact and some threaten the native population and thereby the biological diversity and the nature as such. Among the 80 alien animal species (invertebrates and vertebrates) are five insect species: Agrilus planipennis, Anoplophora glabripennis, Harmonia axyridis, Linepithema humile and Vespa velutina (see Figure 1 and Table 1) (Scheibner et al. 2015).

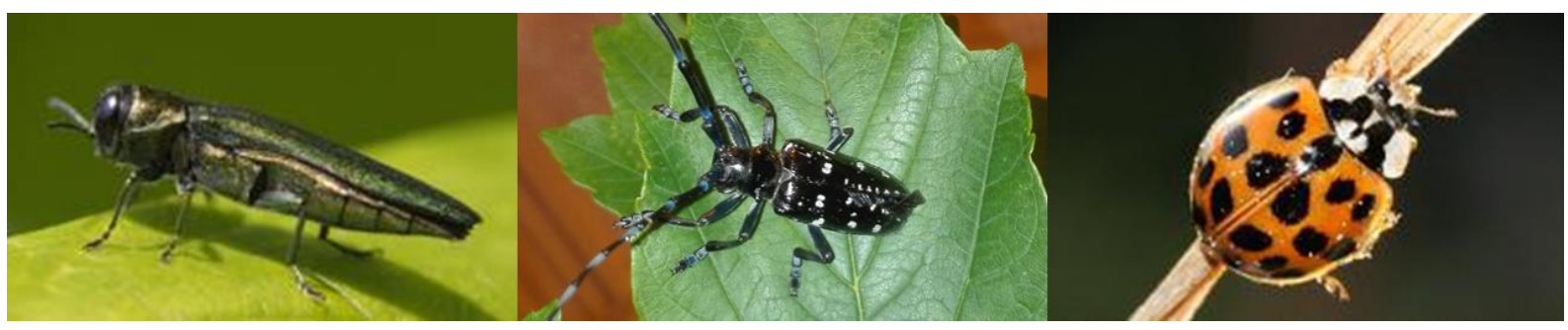

Figure 1: Imagines of Agrilus planipennis (E. Jende, Eppo website), Anoplophora glabripennis (R.Makarow) and Harmonia axyridis (M. Maspero, Eppo website) (EPPO Global Database 2013; Eppo)

One of the main reasons for the increase of alien species is the globalization and consequent imports from foreign countries. For example, species like Harmonia axyridis were intentionally imported as a natural enemy of vermin (Scheibner et al. 2015), while the Asian longhorn beetle (Anoplophora glabripennis (Moschulsky), ALB) was imported in wood pallets used for stoneware transports from Asia. An ALB infestation of trees in open land was first detected in 2001 in Europe and in 2004 in Germany. The ALB is listed among one of the most threatening invasive pests as it infests vital trees, damages their internal liquid supply and thereby leads to the tree's dieback; (Schröder 2014) moreover, its host trees include 29 trees

Table 1: Potentially invasive or invasive beetles published by the Bundesamt für Naturschutz (Scheibner et al. 2015)

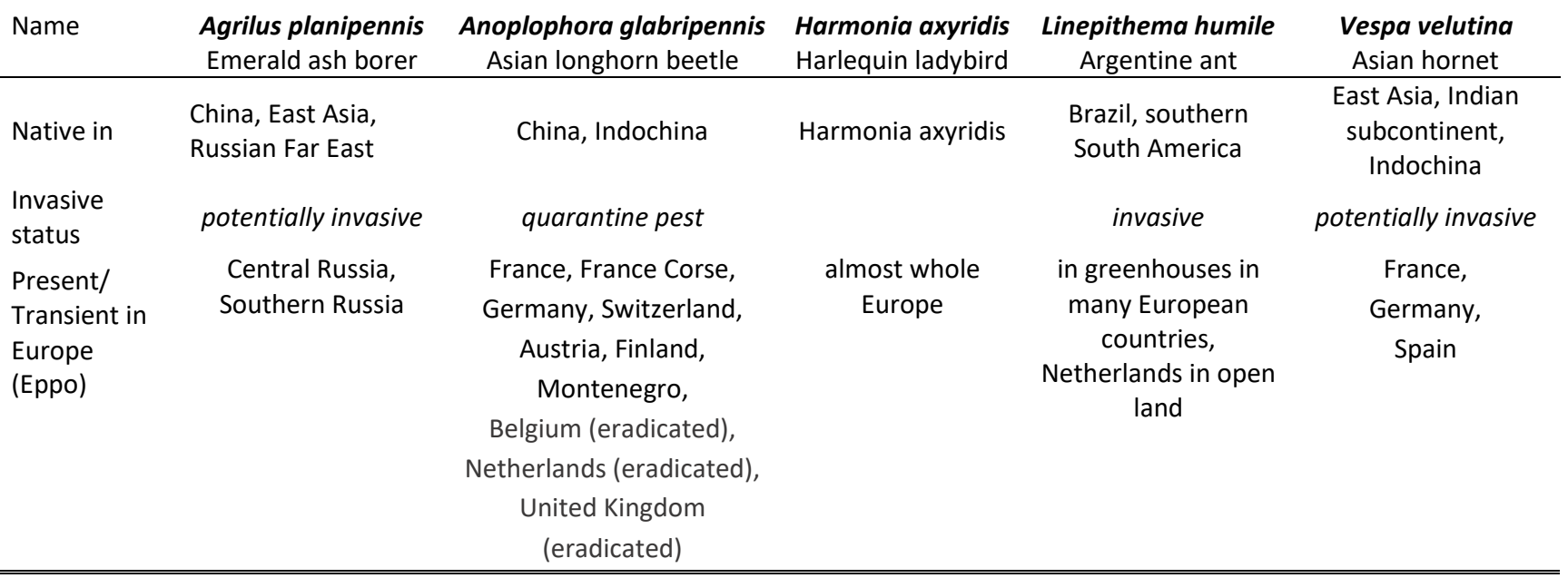


genera (see Table 2) and threaten a major amount of tree population (European Union). Since ALB's first appearance in Europe the amount of infested areas and their expanse have generally increased (Wermelinger 2014).

An exception is the infested area in Neukirchen/Inn, Bavaria, which is regarded as free of infestation after 12 years of countering (EPPO Global Database). In regions of continuing infestations like the Lombardy region, Italy, an eradication is not expected anymore and plant protection services consider their work as control measures. The prognosis for invasive threats is an aggravation of the problem due to climatic changes in Europe and as a consequence, the increase of habitat for invasive pests.

Table 2: Host trees of ALB according to the implementing decision 2015/893 (European Union)

\begin{tabular}{llll}
\multicolumn{2}{l}{ Anoplophora glabripennis host trees } & \\
\hline Acer spp. & Ceridiphyllum spp. & Melia spp. & Salix spp. \\
Aesculus spp. & Corylus spp. & Morus spp. & Sophora spp. \\
Albizia spp. & Elaeagnus spp. & Platanus spp. & Sorbus spp. \\
Alnus spp. & Fagus spp. & Populus spp. & Tilia spp. \\
Betula spp. & Fraxinus spp. & Prunus spp. & Ulmus spp. \\
Buddleja spp. & Hibiscus spp. & Pyrus spp. & \\
Carpinus spp. & Koelreuteria spp. & Quercus rubra & \\
Celtis spp. & Malus spp. & Robinia spp. & \\
\hline \hline
\end{tabular}

Bidinger (Kerstin Bidinger 2012) refers to several publications that show the influence of raising temperature on the development cycle. Institutions with breeding facilities, that host ALB under constant climatic conditions report a reduction of lifecycle from 2 years to 9 months. With regards to the situation in North Italy, rising temperatures may also cause a habitat shift northwards and thereby an expansion of habitat in general (Kerstin Bidinger 2012). Concerning ALB Bidinger expects an aggravation of the problem and an increase of damage in the future. ALB's ability of adaption is named as a main reason. Bradshaw et al. (Bradshaw et al. 2016) numbered the damage of invasive species in Europe per year at US $\$ 3.6$ billion. They name the global trade and global warming as the two main reasons. A growth of $18 \%$ of invasive species in infested areas that already exist is expected till 2050 (Bradshaw et al. 2016). The economic damage ALB may cause just in Germany was valued at 96 Million $€$ (Thomas Schröder). In 2015 the city Magdeburg spent almost 700,000 € countering ALB. In a $45 \mathrm{~km}^{2}$ quarantine zone 4,000 trees were cut down (Dr. Ursel Sperling 2015). With the 'Herrenkrugpark' and the 'Vogelsangpark', two landmarked parks and their valuable tree population are within the quarantine zone (Landesanstalt für Landwirtschaft und Gartenbau 2017) (Landesanstalt für Landwirtschaft und Gartenbau 2019). In 2015 the quarantine zone in Bavaria has reached an expanse of approximately 220 ha and 3,100 trees, approximately 5 ha of wood have been cut down (Dr. Peter Nawroth 2015). Besides economic damage, invasive species are a severe threat for the native biodiversity and tree populations. 
Preventive counter measures are regulated by the International Standard for Phytosanitary Measures (ISPM) 15. According to ISPM 15, wooden pallets for cargo transport either have to be heated or gassed with methyl bromide (Secretariat of the International Plant Protection Convention 2018). According to the Bundesverband für Naturschutz (Germany) though, examinations show that $8 \%$ of ISPM 15 treated pallets are infested (Clever-Rott 2014). With the scope of eradication in the case of infestation, actions according to the Commission Implementing Decision (EU) 2015/893 must be taken. The first step is the implementation of a demarcated area consisting of an infested zone and a buffer zone. The infested zone contains all infested trees and the buffer zone encompasses the infested zones with an extent of at least $2 \mathrm{~km}$. The immediate felling of all infested trees and all ALB host trees in a $100 \mathrm{~m}$ radius around infested trees is mandatory. A regular visual monitoring is carried out within the zone by trained personnel (European Union). Tree climbers are often used to control branches for signs of infestation. These standard actions are costly and time consuming and need personnel resources. These measures are mainly applicable for small infested areas. With the expanse of the infested area, the demand of resources rises for an elaborated monitoring. With an area of about $52 \mathrm{~km}^{2}$ in 2016, Magdeburg is an example for a widely expanded infested area. With their available personnel in 2015, they were able to control the 400,000 trees only once (Dr. Ursel Sperling 2015; Landesanstalt für Landwirtschaft und Gartenbau 2017). A single control is most likely connected to a high probability of overlooking the signs of an infestation —especially a fresh infestation-whose visual tokens are reduced to slight cuts from ovipositions. Generally, the season and thereby the development cycle cannot be taken into account when the infested area is widely expanded, which means that visual symptoms vary. The reliability of these measures for quarantine zones of wide expanse are in doubt.

In some areas pheromone traps are used to control ALB presence. Manoukis et al. (Manoukis et al. 2014) show that the average cumulative capture probability after 30 days is between $4 \%$ and approximately $12 \%$, depending on the trap grid and the attractiveness of the lure. These poor rates are due to ALB's distinct tendency to stay within the host tree and the rarity of flight periods and adult emergence. The author suggests alternative detection methods as they may outperform the efficiency of trapping in case of ALB, if the trap attractiveness is low (Manoukis et al. 2014).

A new and adequate approach for the control of widely extended quarantine zones are sniffer dogs. Sniffer dogs have been used recently for the detection of ALB (Dr. Doris Hölling 2016). When diligently trained, they offer the possibility of screening large areas in a short time with several advantages like fast detection, wide applicability and high sensitivity. Besides exhaustion, the influence parameters on sniffer dogs' indication and a day-dependent variance of performance, the quality of training is the main limitation of sniffer dogs' performance. Especially the choice of training aids must be considered carefully. Training aids should offer the scent of the species of interest; however, the work with the living species in its different development stages is not possible due to quarantine regulations. Working with dead material does not necessarily offer the scent of living insects, as the dead insects undergo decomposition and the decarboxylation of amino acids, resulting in smelling amines (Legrum 2011). 
When working with a target odour consisting of a variety of VOCs, it is not yet known which substances play a role in dogs' decision; however, Dahlenburg (Dahlenburg 2016) were able to show that a specification of the target substance for sniffer dogs' training leads to an enhancement in positive indication rates concerning drugs. Thus, more effort has to be put into the investigation of VOCs of the sniffer dog's target substance, considering a difference in odour between the different sources and an ageing process for chemical and biological targets. The knowledge and use of target specific odorous substances can lead to a significant improvement in sniffer dog's training and, as a result, discriminating capacity. The knowledge of target substances is also required for the development of technical detectors based on sensory systems. This work focuses on the development of a method for the investigation of the VOCs emitted by ALB and the distinction to native insect species' VOCs with the scope of pointing out the ALBspecific VOCs and the proof with sniffer dogs as ALB detectors.

\subsection{FUndAMENTALS}

'The task of isolating trace quantities of flavouring compounds from biological systems [...] for instrumental analysis is formidable.' (Gary A. Reineccius), the statement by Gary A. Reineccius, flavour chemist, put the complexity of this topic straight. Not only do thousands of flavouring compounds exist (most natural sources are composed of several hundred flavourings or volatile organic compounds), they also have a broad range of chemical and physical properties. The main properties of VOCs and what makes them odorants, techniques of gaining them, and some typical VOC patterns of backgrounds are presented in this chapter.

\subsubsection{Volatile organic compounds}

Environmental samples contain thousands of organic compounds (Christensen et al. 2018). Biogenic volatile organic compounds (BVOC) are mainly emitted from vegetation (Gonzaga Gomez et al. 2019). VOC are called volatile for their higher saturated vapour pressure $\left(\geq 0.01 \mathrm{kPa}\right.$ at $\left.20^{\circ} \mathrm{C}\right)$, low boiling point and small molecular weight (Wang et al. 2018b) up to $300 \mathrm{u}$ (Legrum 2011). Molecules of higher masses with olfactory character are rare (Legrum 2011). The emitted concentrations are typically from low ppt to high ppb (Woolfenden 2011). The sources of VOCs 


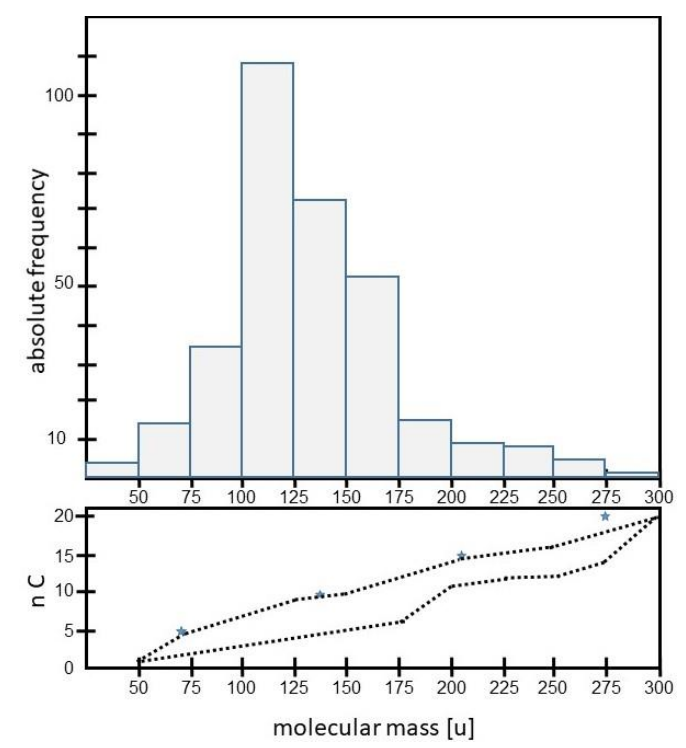

Figure 2: Frequency distribution of the relative molecular mass (MM) of 320 odorants. Intervals include the lower mass and exclude the higher mass. The figure below shows correspondingly the minimal and maximal amount of C-atoms (Legrum 2011).

are diverse: the main sources are anthropological and biological, whereas the amount of biogenic VOCs is suggested to be higher than the anthropological (Wang et al. 2018b) (Albers et al. 2018; Ahn et al. 2016). The emission of VOCs from plants have different roles. Typically plants emit VOCs as a reaction to stress (Cellini et al. 2018). Volatile organic substances do not necessarily have an odorous character. Odorants are volatile substances that are capable of binding to olfactory receptors (German). Chemically, odorants are classified in four main groups: terpenes, phenyl propane derivatives, esters/lactones and nitrogen- or sulphur-containing substances (Legrum 2011). Terpenes are secondary metabolic compounds. Phenyl propane derivatives result biosynthetically from shikimi acid metabolism (Legrum 2011). They contain a benzene ring and an n-propyl chain. Vanillin, the character impact compound from vanilla, is one of this group's representatives. Odorants fulfil a variety of purposes. The general purpose originates from the goal of survival, which includes warning of enemies, detection of feed and reproduction (Legrum 2011). Terpenes, for example, work as an attraction for insects with the goal of pollination as well as defence against predators (Breitmaier 2005). Sesquiterpenes function as antibiotic compounds produced by plants in response to microbial challenge and as antifeedant that discourage herbivory (Thelen et al. 2005; Croteau et al. 2000). As the emission of VOCs fulfil a range of functions, among them carrying information, a change of emission pattern may also implicate information about the state of the emitter. For different bacterial (Mentana et al. 2019), viral (Rajabaskar et al. 2013; Saad et al. 2019) and fungal (Gamlath Mohottige et al. 2018; Laothawornkitkul et al. 2010) pathogens, difference in VOC emissions between healthy and infested plants could be proven. This change in VOC emission has lately been used for diagnostic reasons like human diseases (Mochalski et al. 2018; Dutta et al. 2018; Gonzaga Gomez et al. 2019; Pizzini et al. 2018; Wang et al. 2018a) and health threats (Cao et al. 2019; Ruokolainen und Hyttinen 2019; Brown et al. 2014). 


\subsubsection{Techniques of VOC sampling}

Over many years, different kinds of techniques for the isolation of scent have been developed, depending on the characteristics of the target analyte and the matrix. Established techniques are the isolation of scent with distillation, the extraction of odorants with solvents and adsorption techniques.

The distillation uses the specific volatile character of odorants. With increasing temperatures or/and decreasing pressure. the vapour pressure raises and thereby the tendency of the odorants to enter the gas phase increases. The odorants condense on a cooler and are collected. With this procedure, water is also usually distilled and a following drying step is needed (Gary A. Reineccius). Steam distillation is a special type of distillation that uses the low boiling point of water to carry small amounts of hydrophobic substances to the condensation flask. The condensed liquid phase separates and can easily be collected.

The extraction of odorants with solvents is a gentle method as heat supply can be avoided. Fragile odorants can thereby be preserved and collected. The main challenge of this method is the insufficient selectivity of solvent. Hydrophobic solvents dissolve not only odorants from the sample but all types of lipophilic substances like fats (Gary A. Reineccius).

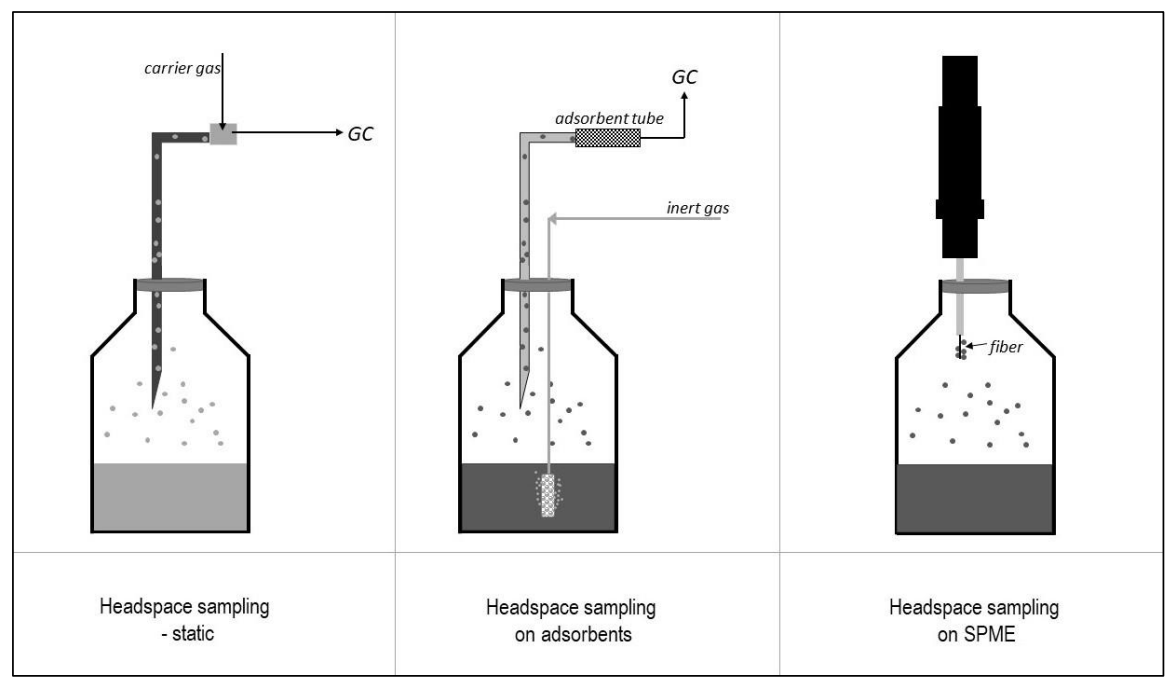

Figure 3: Different headspace sampling techniques

Adsorption techniques are solvent-free, easy to apply and, in the case of adsorbent tubes, provide an enrichment of VOCs and thereby the possibility of an increase in sensitivity. The most popular application of this technique is the enrichment of airborne volatiles on an adsorbent packed tube. A similar method is the solid phase extraction (SPE). The adsorbent is fixed in a carrier material. After conditioning the sorbent, the liquid sample is added and passes through the stationary phase. Either the analytes of interest remain on the stationary phase and are eluted in an additional step or the undesired matrix remains on the stationary phase and the analytes pass through the stationary phase and are collected. Another established technique is the solid phase micro extraction (SPME). An inert needle covered with a thin layer of adsorbent 
is used for the collection of volatiles. SMPE can be used for liquid and gaseous samples. It is commonly used for static headspace analysis (see Figure 3). This method is limited by the capacity of the needle surface and the competing enrichment of molecules. Besides, ageing of the fibre leads to performance losses after approximately 100 uses (Gary A. Reineccius). A special type of this principle is the stir bar sorptive extraction (SBSE), a sorbent covered stir bar that is used to enrich liquid and gaseous samples. The surface is bigger than for SPME, allowing a significant amount of analyte to be enriched and therefore a better sensitivity. Anyway, the enrichment is limited by an equilibration of analyte adsorbed on the stir bar or fibre and analyte in the gaseous or liquid sample. An increase of enrichment of analytes is possible when using a dynamic headspace. For dynamic sampling a sorbet tube is used and the sample is actively passed over the adsorption material.

One of the main challenges of airborne VOC analysis is the representability and therefore the reproducibility of sampling. Sampling volumes are typically in the range of some millilitres to a few litres. Depending on the sample, different issues occur when taking a sample with regards to representability: in the case of surveillance of room air and health threats, convections and fluxes can determine the distribution of VOCs in the room. In the case of the analysis of plants, VOC emission determining factors that need to be considered are daytime, state of health and temperature. When sampling on adsorption tubes an increase of sampled air volume could be a possible solution, but as adsorption is a physico-chemical process undergoing states of adsorption and desorption, a transport of substance does still take place. When sampled substances are lost again due to high volumes the so called breakthrough volume is reached. The breakthrough volume is depending on the substance/adsorbent combination. The adsorption material can be adapted to the question of analysis and thereby increase the breakthrough volume and the sensitivity for target substances. The detachment from disturbing background matrix is also possible when known. The development of a sample- and question-adapted sampling method is essential for a qualitative and quantitative analysis of VOCs (Figge et al. 1987).

\subsubsection{Chemical background}

Volatile organic compounds are omnipresent. They are indoors and outdoors and their pattern changes depending on the surrounding setting. Forest areas differ from rural and urban areas, and within a rural area industry, traffic and housing areas cause different emissions of VOCs. The main natural sources of VOCs are from plant emissions and the main human sources are automobile exhaust, fuel volatilization and coating use (Wang et al. 2018b). Generally, the chemical background as a whole is local and temporary (Wang et al. 2018b). Generally, some assertions can be made: the main components of VOCs in the atmosphere are aromatic hydrocarbons, alkanes and alkenes. The concentration of VOCs in summer and winter in urban atmosphere is higher than in spring and autumn (Wang et al. 2018b). 
Table 3: Some compound examples from urban, rural and forest air

\begin{tabular}{lll}
\hline \hline $\begin{array}{l}\text { Examples in urban and industrial } \\
\text { air (Woolfenden 2011) }\end{array}$ & $\begin{array}{l}\text { Examples in rural and } \\
\text { forest air (Woolfenden 2011) }\end{array}$ & $\begin{array}{l}\text { Examples in forest air (Aydin et } \\
\text { al. 2014) }\end{array}$ \\
\hline MTBE & heptanal & isoprene \\
benzaldehyde & octanal & sabinene \\
phenol & nonanal & limonene \\
acetic acid & decanal & trans- $\beta$-ocimene \\
2-butanone & 6-methyl, 5-hepten-2-one & trans-caryophyllene \\
2-pentanone & acetophenone & iso-longifolene \\
4-methylcyclo-hexanone & hexanal & $\alpha$-bergamotene \\
n-butanol & & E,E- $\alpha$-farnesene \\
2-butanol & & $\beta$-selinene \\
hexanal & $\alpha$-pinene \\
& & eucalyptol \\
& linalool-L \\
\hline \hline
\end{tabular}

But there are some single substances and classes of substances that can be more frequently found in the different surroundings. In Table 3 some published examples for compounds in urban and industrial, and rural and forest air are listed. When the analysis of VOCs of a sample under real circumstances is done, the chemical background needs to be considered as it is an additional source for VOCs during sampling. For the analysis in open land environment, the background will be part of the sampling. The enrichment of background can lead to an overlay of peaks in the chromatographic analysis or falsify quantitative analysis. For the use of detectors, the background can completely mask target substances and result in a false negative result. The influence of the chemical background can be excluded when using a sampling chamber flushed with inert gas.

\subsection{SCOPE OF THIS WORK}

The scope of this work was to identify the specific volatile organic compounds emitted by Anoplophora glabripennis in the different stages of development (Part I).

In the case of Anoplophora glabripennis nothing is yet published about the VOC emissions of samples or infested host plants. There are few publications that investigate the pheromones of ALB, and therefore the analysis of the eluted substances from Anoplophora glabripennis imagines was carried out. Zhang et al. collected the airborne VOCs emitted by ALB imagines and analysed the EAD response. He concluded that 4-(n-heptyloxy)butanal and 4-(n-heptyloxy)butan-1-ol act as information carrier (Zhang et al. 2002). A substance screening has not been published. Crook et al. detected a third potential pheromone (3E, 6E)- $\alpha$-farnesene. The sampling technique was similar to the technique Zhang described (Crook et al.). Except for (Z)-9-tricosane, (Z)-9-pentacosane, (Z)-7-pentacosane and the pheromones also published by Zhang (4-(n-heptyloxy)butan-1-ol and 4-(n-heptyloxy)butanal), no VOCs have been published.

For different prospective applications that fulfil the demand of contactless detection via air, the investigation of the specific volatile organic compounds emitted by ALB is required. Therefore, the screening of the emitted VOCs of ovipositions, larvae and imagines was carried out. A focus was put on the development of the analytical method meaning the most efficient sampling parameters, the choice of 
adsorption material and the thermal desorption GC/MS parameters. Because of enrichment limitations for SPME and SBSE, the dynamic enrichment on adsorption tubes was chosen as the sampling technique. Extraction and distillation were not appropriate for the sample types considering the complete development cycle of ALB including ovipositions on tree trunks. The best sampling flexibility was offered by the VOC sampling on adsorption tubes. Based on the recommendations by Figge et al., Carbotrap, Porapak Q, Tenax $T A \circledast$ and Tenax GR® were tested with a focus on amount of VOCs trapped and concentration thereof. As the literature only reveal little information about gaseous VOCs emitted by ALB, all substance groups had to be taken into account. Adapted to the best performing adsorbent Tenax TA® and Tenax GR®, the desorption parameters and the GC/MS parameters were determined. The developed overall analytical method was used in Parts I and II.

In Part I the VOCs emitted from ALB larvae, imagines and ovipositions were determined. In Part II the volatile organic compounds of healthy trees of the species Salix, Acer and Populus, mechanically stressed Acer and a selection of native insect species (Zeuzera pyrina, Saperda carcharias, Cossus cossus, Aromia moschata) were analysed. The goal was to extract the ALB-specific VOCs among these qualified in Part I. Furthermore, host trees in open land environment were analysed, as well as the open land background, in order to investigate the influence of the chemical background in open land.

In Part III the extracted VOCs were used for a synthetic mixture for ALB scent and experiments with ALBconditioned sniffer dogs were carried out to examine if the sniffer dogs recognize the synthetic mixture as ALB scent. Certified technical detectors for ALB are not yet available. The only ALB detectors available are sniffer dogs. They are used for this purpose since 2009 and even longer for other purposes (Hoyer-Tomiczek und Sauseng 2009).

Sniffer dogs have been used for a variety of purposes: for health reasons like the detection of cancer (Boedeker et al. 2012; Elliker et al. 2014; Guerrero-Flores et al. 2017; Hackner et al. 2016; Panebianco et al. 2018; Schallschmidt et al. 2016; Seo et al. 2018; Willis et al. 2010) as well as for the search for corpses (human remains detection) (DeGreeff und Furton 2011), bacteria in milk (Fischer-Tenhagen et al. 2018) or wildlife detection (Georgina Mills 2018). DeGreef et al. were able to show distinct differences concerning the VOC odour profiles of deceased bodies, living human objects and animal remains (DeGreeff und Furton 2011). The identification of VOCs plays an important role, but little is known about the detection of relevant substances as such. Dog handlers often train their dogs with chemically undefined and unstable training aids and thereby shape their detector imprecisely, which leads to an increase in false indications. For detection dogs, as well as for technical detectors, it is essential to point out the specific VOCs or the specific combination of VOCs in a pattern (so called 'fingerprint'). Commonly available technical detectors like GDA or Itemizer are used for the detection of drugs or/and explosives, which are chemically well-known and specified to a single substance or-in the case of intoxicating agents-few substance-combinations. With regards to biological (living) targets, little is known about their specific emission.

In order to verify the ALB specific substances, some effort has been put into the planning and realisation of experiments with ALB-trained sniffer dogs. In Part III the experiments are described and the results of 
the sniffer dogs' indication confirms the recognition of ALB scent when using a mixture of ALB specific terpenes. For these experiments a tool that works as a collector and carrier of odorous substances and is suitable for the search with sniffer dogs was developed. 


\subsection{RefERENCES}

Acosta, André L.; Giannini, Tereza C.; Imperatriz-Fonseca, Vera L.; Saraiva, Antonio M. (2016): Worldwide Alien Invasion: A Methodological Approach to Forecast the Potential Spread of a Highly Invasive Pollinator. In: PloS one 11 (2), e0148295. DOI: 10.1371/journal.pone.0148295.

Ahn, Jeong-Hyeon; Kim, Ki-Hyun; Szulejko, Jan E.; Kwon, Eilhann E.; Deep, Akash (2016): Characterization of quality assurance properties of biogenic volatile organic compounds with an emphasis on the breakthrough behavior, recovery, and temporal stability. In: Microchemical Journal 125, S. 142-150. DOI: 10.1016/j.microc.2015.11.016.

Albers, Christian Nyrop; Kramshøj, Magnus; Rinnan, Riikka (2018): Rapid mineralization of biogenic volatile organic compounds in temperate and Arctic soils. In: Biogeosciences 15 (11), S. 3591-3601. DOI: 10.5194/bg-15-3591-2018.

Aydin, Yagmur Meltem; Yaman, Baris; Koca, Husnu; Dasdemir, Okan; Kara, Melik; Altiok, Hasan et al. (2014): Biogenic volatile organic compound (BVOC) emissions from forested areas in Turkey: determination of specific emission rates for thirty-one tree species. In: The Science of the total environment 490, S. 239253. DOI: 10.1016/j.scitotenv.2014.04.132.

Boedeker, Enole; Friedel, Godehard; Walles, Thorsten (2012): Sniffer dogs as part of a bimodal bionic research approach to develop a lung cancer screening. In: Interactive CardioVascular and Thoracic Surgery (14), S. 511-514. Online verfügbar unter 10.1093/icvts/ivr070.

Bradshaw, Corey J. A.; Leroy, Boris; Bellard, Céline; Roiz, David; Albert, Céline; Fournier, Alice et al. (2016): Massive yet grossly underestimated global costs of invasive insects. In: Nature communications 7, S. 12986. DOI: $10.1038 /$ ncomms12986.

Breitmaier, Eberhard (2005): Terpene. Aromen, Düfte, Pharmaka, Pheromone. 2. Aufl. 1 Band. Darmstadt: WILEY-VCH Verlag GmbH \& Co. KGaA.

Brown, Veronica M.; Crump, Derrick R.; Plant, Neil T.; Pengelly, lan (2014): Evaluation of the stability of a mixture of volatile organic compounds on sorbents for the determination of emissions from indoor materials and products using thermal desorption/gas chromatography/mass spectrometry. In: Journal of chromatography. A 1350, S. 1-9. DOI: 10.1016/j.chroma.2014.05.011.

Cao, Shurui; Wen, Yao; Xi, Cunxian; Li, Xianliang; Zhang, Lei; Wang, Guomin; Shang, Jingchuan (2019): Development of a method based on thermal desorption-gas chromatography/mass spectrometry for the determination of 103 volatile organic compounds in mattresses. In: International Journal of Environmental Analytical Chemistry, S. 1-22. DOI: 10.1080/03067319.2019.1647187.

Cellini, Antonio; Buriani, Giampaolo; Rocchi, Lorenzo; Rondelli, Elena; Savioli, Stefano; Rodriguez Estrada, Maria T. et al. (2018): Biological relevance of volatile organic compounds emitted during the pathogenic interactions between apple plants and Erwinia amylovora. In: Molecular plant pathology 19 (1), S. 158168. DOI: $10.1111 / \mathrm{mpp} .12509$. 
Christensen, Peter; Dela Cruz, Majbrit; Tomasi, Giorgio; Nielsen, Nikoline J.; Borggaard, Ole K.; Christensen, Jan H. (2018): Chemical Fingerpringt of mobile Volatile Organic Compounds in soil by DH TD GCMS. In: LC+GC Asia Pacific.

Clever-Rott, Carsten (2014): Bund Naturschutz_ Asiatischer Laubholzbockkäfer bedroht Englischen Garten - Der kleine Killer- am 27-06-16. Der kleine Killer. In: Wochenanzeiger München, 19.11.2014. Online verfügbar unter https://www.wochenanzeiger.de/article/157257.html, zuletzt geprüft am 02nd Oct 2019. Crook, Damon J.; Lance, David R.; Mastro, Victor C.: Crook2014_Article_IdentificationOfAPotentialThir. Croteau, Rodney; Lewis, Norman G.; Kutchan, Toni M. (2000): natural products. secondary metabolites. In: Biochemistry \& Molecular Biology of Plants, S. 1250-1318.

Dahlenburg, Rainer (2016): Der Rauschgiftspürhund auf dem Weg in die Zukunft? In: Christine Schüler und Peter Kaul (Hg.): Faszinosum Spürhunde Gefahren sichtbar machen- Gefahren abwenden. Tagungsergebnisse des 3. Symposiums für Odorologie im Diensthundewesen an der Hochschule BonnRhein-Sieg, Bd. 1. 3. Symposium für Odorologie. Rheinbach, 06.-08.09. 1. Aufl. Hamburg: Dr. Kovac $\mathrm{GmbH}, 267-275$.

DeGreeff, Lauryn E.; Furton, Kenneth G. (2011): Collection and identification of human remains volatiles by non-contact, dynamic airflow sampling and SPME-GC/MS using various sorbent materials. In: Anal Bioanal Chem (401), S. 1295-1307. Online verfügbar unter 10.1007/s00216-011-5167-0.

Dr. Doris Hölling (2016): Der Asiatische Laubholzbockkäfer in Europa. WSL, CH. Online verfügbar unter https://www.waldwissen.net/waldwirtschaft/schaden/invasive/wsl_alb_europa/index_DE， zuletzt aktualisiert am 03.10.2016, zuletzt geprüft am 02nd Oct 2019.

Dr. Peter Nawroth (2015): Aktueller Stand der Bekämpfung des Asiatischen Laubholzbockkäfers in Bayern. Stand 04. Dezember 2015. Fachgespräche zum Management des Asiatischen Laubholzbockkäfers in Deutschland. Bayrische Landesanstalt für Landwirtschaft. Julius-Kühn-Institut. Braunschweig, 07.12.2015. Dr. Ursel Sperling (2015): Asiatischer Laubholzbockkäfer in Magdeburg. - Sachstand und Perspektive der Überwachung und Bekämpfung. Fachgespräche zum Management des Asiatischen Laubholzbockkäfers in Deutschland. Julius-Kühn-Institut. Thomas Schröder. Braunschweig, 07.12.2015.

Dutta, Dibyendu; Chong, Ngee S.; Lim, Seah H. (2018): Endogenous volatile organic compounds in acute myeloid leukemia: origins and potential clinical applications. In: Journal of Breath Research 12 (3), S. 34002. DOI: 10.1088/1752-7163/aab108.

Elliker, Kevin R.; Sommerville, Barbara A.; Broom, Donald M.; Neal, David E.; Armstrong, Sarah; Wiliams, Hywel C. (2014): Key considerations for the experimental training and evaluation of cancer odour detection dogs: lessons learnet from a double-blind, controlled trial of prostate cancer detection. In: BMC Urology (14-22). Online verfügbar unter 10.1186/1471-2490-14-22.

Eppo: Harmonia axyridis (HARNAX). EPPO Global Database, zuletzt geprüft am 05.09.2019. 
EPPO Global Database: Anoplophora glabripennis (ANOLGL). Distribution details in Germany, zuletzt geprüft am $01^{\text {st }}$ Oct 2019.

EPPO Global Database (2013): Agrilus planipennis (AGRLPL). Eppo. Online verfügbar unter https://gd.eppo.int/taxon/AGRLPL, zuletzt geprüft am 01st Oct 2019.

European Union: COMMISSION IMPLEMENTING DECISION (EU) 2015/ 893 - of 9 June 2015 as regards measures to prevent the introduction into and the spread within the Union of Anoplophora glabripennis (Motschulsky) - (notified under document C(2015) 3772), zuletzt geprüft am 01 ${ }^{\text {st }}$ Oct 2019.

Figge, K.; Rabel, W.; Wieck, A. (1987): Adsorptionsmittel zur Anreicherung von organischen Luftinhaltsstoffen. Experimentelle Bestimmung von spezifischen Retentions- und Durchbruchsvolumina. In: Fresenius' Zeitschrift für Analytische Chemie (327(3-4)), S. 261-278.

Fischer-Tenhagen, C.; Theby, V.; Krömker, V.; Heuwieser, W. (2018): Detecting Staphylococcus aureus in milk from dairy cows using sniffer dogs. In: Journal of Dairy Science 101 (5), S. 4317-4324. DOI: 10.3168/jds.2017-14100.

Furton, Kenneth G.; Caraballo, Norma Iris; Cerreta, Michelle M.; Holness, Howard K. (2015): Advances in the use of odour as forensic evidence through optimizing and standardizing instruments and canines. In: Philosophical Transactions: Biological Sciences 370 (1674), S. 1-13. Online verfügbar unter http://www.jstor.org/stable/24505154.

Gamlath Mohottige, Chathuri; She, Jinyan; Misna, Todd; Baird, Richard; Bigham, Reed (2018): Analysis if volatile organic compounds from M. phaseolina fungi infected sweet potatoes. In: Abstract of Papers, $25^{\text {th }}$ ACS National Meeting \& Exposition, AGFD-99.

Gary A. Reineccius: Flavour-Isolation Techniques. Unter Mitarbeit von Gary A. Reineccius. In: Flavours and Fragrances, 409-426.

Georgina Mills (2018): Sniffer dogs to help combat wildlife crime. In: The Veterinary record 183 (12), S. 370-371. DOI: 10.1136/vr.k4089.

German, J. Bruce: Olfaction, where Nutrition, Memory and Immunity intersect. In: Flavours and Fragrances, S. $25-41$.

Gonzaga Gomez, Lais; Loubet, Benjamin; Lafouge, Florence; Ciuraru, Raluca; Buysse, Pauline; Durand, Brigitte et al. (2019): Comparative study of biogenic volatile organic compounds fluxes by wheat, maize and rapeseed with dynamic chambers over a short period in northern France. In: Atmospheric Environment 214, S. 116855. DOI: 10.1016/j.atmosenv.2019.116855.

Guerrero-Flores, Héctor; Apresa-García, Teresa; Garay-Villar, Ónix; Sánchez-Pérez, Alejandro; FloresVillegas, David; Bandera-Calderón, Artfy et al. (2017): A non-invasive tool for detecting cervical cancer odor by trained scent dogs. In: BMC cancer 17 (1), S. 79. DOI: 10.1186/s12885-016-2996-4. 
Hackner, Klaus; Errhalt, Peter; Mueller, Michael Rolf; Speiser, Manulea; Marzluf, Beatrice A.; Schulheim, Andrea et al. (2016): Canine scent detection for the diagnosis of lung cancer in a screening-like situation. In: Journal of Breath Research 10 (4), S. 46003. DOI: 10.1088/1752-7155/10/4/046003.

Hoyer-Tomiczek, Ute; Sauseng, Gabriele (2009): Spürhunde erschnüffeln Quarantäneschädlinge ALB und CLB. In: Forstschutz aktuell (48). Online verfügbar unter https://bfw.ac.at/400/pdf/fsaktuell_48_1.pdf, zuletzt geprüft am 03rd Oct 2019.

JKI, Institut für nationale und internationale Angelegenheiten der Pflanzengesundheit (2016): Notfallplan und Leitlinie zur Bekämpfung von Anoplophora glabripennis in Deutschland. In: Bundesanzeiger (BAnz AT 10.01.2017 B5), S. 1-82. Online verfügbar unter https://www.juliuskuehn.de/media/Neroeffentlichungen/Bekanntmachungen/019_BAnz_AT_10.01.2017_B5_Leitlinie_ALB.p df.

Kerstin Bidinger (2012): Schadpotenzial gebietsfremder, invasiver Käferarten unter Berücksichtigung des globalen Klimawandels und rechtlicher Aspekte. Online verfügbar unter https://ubt.opus.hbznrw.de/frontdoor/index/index/docld/544.

Landesanstalt für Landwirtschaft und Gartenbau (2017): Jahresbericht 2016. der Landesanstalt für Landwirtschaft und Gartenbau Sachsen-Anhalt. Hg. v. Landesanstalt für Landwirtschaft und Gartenbau.

Landesanstalt für Landwirtschaft und Gartenbau (2019): Allgemeinverfügung der LLG über Maßnahmen zur Bekämpfung des ALB. Anlage 3- Übersicht Quarantänezone. Hg. v. Landesanstalt für Landwirtschaft und Gartenbau. Bernburg. Online verfügbar unter https://llg.sachsenanhalt.de/fileadmin/Bibliothek/Politik_und_Verwaltung/MLU/LLFG/Dokumente/04_themen/pflanzenschutz /alb_dokumente/19_alb_allgemeinverfueg_2019-06-04.pdf, zuletzt geprüft am 2nd Oct 2019.

Laothawornkitkul, J.; Jansen, R. M.; Smid, H. M.; Bouwmeester, H. J.; Muller, J.; van Bruggen, A. H. (2010): Volatile organic compounds as a diagnostic marker of late blight infected potato plants: A pilot study. In: Crop Protection (29), S. 872-878. Online verfügbar unter doi:10.1016/j.cropro.2010.03.003.

Legrum, Wolfgang (2011): Riechstoffe, zwischen Gestank und Duft. Vorkommen, Eigenschaften und Anwendung von Riechstoffen und deren Gemischen. Wiesbaden: Vieweg+Teubner Verlag / Springer Fachmedien Wiesbaden $\mathrm{GmbH}$ Wiesbaden (Studienbücher Chemie). Online verfügbar unter http://dx.doi.org/10.1007/978-3-8348-8276-9.

Makarow, Ramona; Schäfer, Sara; Albrecht, Stephan; Robert, Simon; Schütz, Stefan; Kaul, Peter (2019): Investigation of volatile organic compounds emitted by Anoplophora glabripennis (Moschulsky) using thermal desorption and gas chromatography-mass spectrometry. In: Microchemical Journal 146, S. 142148. DOI: 10.1016/j.microc.2018.12.036.

Manoukis, Nicholas C.; Hall, Brian; Geib, Scott M. (2014): A computer model of insect traps in a landscape. In: Scientific reports 4, S. 7015. DOI: 10.1038/srep07015. 
Mentana, Annalisa; Camele, Ippolito; Mang, Stefania M.; De Benedetto, Giuseppe E.; Frisullo, Salvatore; Centonze, Diego (2019): Volatolomics approach by HS-SPME-GC-MS and multivariate analysis to discriminate olive tree varieties infected by Xylella fastidiosa. In: Phytochemical Analysis. Online verfügbar unter DOI: 10.1002/pca.2835.

Mochalski, Pawel; Leja, Marcis; Gasenko, Evita; Skapars, Roberts; Santare, Daiga; Sivins, Armands et al. (2018): Ex vivo emission of volatile organic compounds from gastric cancer and non-cancerous tissue. In: Journal of Breath Research 12 (4), S. 46005. DOI: 10.1088/1752-7163/aacbfb.

Panebianco, Concetta; Kelman, Edgar; Vene, Kristel; Gioffreda, Domenica; Tavano, Francesca; Vilu, Raivo et al. (2018): Cancer sniffer dogs: how can we translate this peculiarity in laboratory medicine? Results of a pilot study on gastrointestinal cancers. In: Clinical Chemistry and Laboratory Medicine (CCLM) 56 (1). DOI: $10.1515 / \mathrm{cclm}-2016-1158$.

Pizzini, Alex; Filipiak, Wojciech; Wille, Johannes; Ager, Clemens; Wiesenhofer, Helmut; Kubinec, Róbert et al. (2018): Analysis of volatile organic compounds in the breath of patients with stable or acute exacerbation of chronic obstructive pulmonary disease. In: Journal of Breath Research 12 (3), S. 36002. DOI: 10.1088/1752-7163/aaa4c5.

Rajabaskar, D.; Ding, H.; Wu, Y.; Eigenbrode, S. D. (2013): Differ React of Potato Varieties to Infect by Potato Leafroll Virus and Assoc Resp by its Vector. In: Journal of chemical ecology (39), S. 1027-1035. Online verfügbar unter DOI 10.1007/s10886-013-0311-2.

Ruokolainen, Joonas; Hyttinen, Marko (2019): Cleaning workers' exposure to volatile organic compounds and particulate matter during floor polish removal and reapplication. In: Journal of Occupational and Environmental Hygiene, S. 1-9. DOI: 10.1080/15459624.2019.1646915.

Saad, Khalid A.; Rolff, M. Mohamad; Hallett, Rebecca H.; Abd-Ghani, Idris B. (2019): Effects of cucumber mosaic virus-infected chilli plants on non-vector Bemisia tabaci (Hemiptera: Aleyrodidae). In: Insect Science (26), S. 76-85. Online verfügbar unter DOI 10.1111/1744-7917.12488.

Schallschmidt, Kristin; Becker, Roland; Jung, Christian; Bremser, Wolfram; Walles, Thorsten; Neudecker, Jens et al. (2016): Comparison of volatile organic compounds from lung cancer patients and healthy controls—challenges and limitations of an observational study. In: Journal of Breath Research 10 (4), S. 46007. DOI: 10.1088/1752-7155/10/4/046007.

Scheibner, Cornelia; Roth, Mechthild; Nehring, Stefan; Schmiedel, Doreen; Wilhelm, Eckehard-G.; Winter, Susanne (Hg.) (2015): Management-Handbuch zum Umgang mit gebietsfremden Arten in Deutschland. Band 2: Wirbellose Tiere und Wirbeltiere. Bundesamt für Naturschutz. 2 Bände. Münster: BfNSchriftenvertrieb im Landwirtschaftsverlag GmbH (Naturschutz und biologische Vielfalt, 141(2)).

Schröder, Thomas (2014): Anoplophora glabripennis. Asiatischer Laubholzbockkäfer. Julius-Kühn-Institut. 
Secretariat of the International Plant Protection Convention (2018): Regulation of wood packaging material in international trade. ISPM 15. Online verfügbar unter https://pflanzengesundheit.juliuskuehn.de/dokumente/upload/ISPM_15_2018_En_2018-05-16.pdf.

Seo, In-Seok; Lee, Hwan-Gon; Koo, Bonkon; Koh, Chin Su; Park, Hae-Yong; Im, Changkyun; Shin, HyungCheul (2018): Cross detection for odor of metabolic waste between breast and colorectal cancer using canine olfaction. In: PloS one 13 (2), e0192629. DOI: 10.1371/journal.pone.0192629.

Sophie Marchal, Olivier Bregeras, Didier Puaux, Rémi Gervais, Barbara Ferry (2016): Rigorous Training of Dogs Leads to High Accuracy in Human Scent Matching-To-Sample Performance. In: PloS one (11(2)). Online verfügbar unter 10.1371/journal.pone.0146963.

Thelen, John; Harbinson, Jeremy; Jansen, Roel; van Straten, Gerrit; Posthumus, Maarten A.; Woltering, Ernst J.; Bouwmeester, Harro J. (2005): The sesquiterpene $\alpha$-copaene is induced in tomato leaves infected by Botrytis cinerea. In: Journal of Plant Interactions 1 (3), S. 163-170. DOI: 10.1080/17429140600968177. Thomas Schröder: Leitlinie zur Bekämpfung des Asiatischen Laubholzbockkäfers Anoplophora glabripennis in Deutschland. JKI, Institut für nationale und internationale Angelegenheiten der Pflanzengesundheit.

Trotter, R. Talbot; Keena, Melody A. (2016): A Variable-Instar Climate-Driven Individual Beetle-Based Phenology Model for the Invasive Asian Longhorned Beetle (Coleoptera: Cerambycidae). In: Environmental entomology 45 (6), S. 1360-1370. DOI: 10.1093/ee/nvw108.

Wang, Min; Sheng, Jiajing; Wu, Qian; Zou, Yingchang; Hu, Yanjie; Ying, Kejing et al. (2018a): Confounding effect of benign pulmonary diseases in selecting volatile organic compounds as markers of lung cancer. In: Journal of Breath Research 12 (4), S. 46013. DOI: 10.1088/1752-7163/aad9cc.

Wang, Qi; Wang, Chēn; Hou, Lujian; Lv, Bo; WANG, Chén (2018b): Pollution data analysis and characteristics of volatile organic compounds in the environment. In: E3S Web Conf. 38 (10), S. 1004. DOI: 10.1051/e3sconf/20183801004.

Wermelinger, Beat (2014): Invasive Gehölzinsekten: Bedrohung für den Schweizer Wald? In: Schweizerische Zeitschrift fur Forstwesen 165 (6), S. 166-172. DOI: 10.3188/szf.2014.0166.

Wermelinger, Beat; Forster, Beat; Hölling, Doris; Plüss, Therese; Raemy, Otto; Klay, Alfred (2015): Invasive Laubholz-Bockkäfer aus Asien. Ökologie und Management. Merkblatt für die Praxis. 2. Aufl. Eidg. Forschungsanstalt WSL. Birmensdorf, Schweiz (ISSN 2296-4428).

Willis, Carolyn M.; Britton, Lezlie E.; Harris, Rob; Wallace, Joshua; Guest, Claire M. (2010): Volatile organic compounds as biomarkers of bladder cancer: Sensitivity and specificity using trained sniffer dogs. In: Cancer biomarkers : section A of Disease markers 8 (3), S. 145-153. DOI: 10.3233/CBM-2011-0208.

Woolfenden, Elizabeth (2011): Monitoring VOCs in Air Using Sorbent Tubes Followed by Thermal Desorption-Capillary GC Analysis: Summary of Data and Practical Guidelines. In: Journal of the Air \& Waste Management Association 47 (1), S. 20-36. DOI: 10.1080/10473289.1997.10464411. 
Xu, Tian; Yasui, Hiroe; Teale, Stephen A.; Fujiwara-Tsujii, Nao; Wickham, Jacob D.; Fukaya, Midori et al. (2017): Identification of a male-produced sex-aggregation pheromone for a highly invasive cerambycid beetle, Aromia bungii. In: Scientific reports 7 (1), S. 7330. DOI: 10.1038/s41598-017-07520-1.

Zhang, Aijun; Oliver, James E.; Aldrich, Jeffrey R.; Wang, Baode; Mastro, Vic C. (2002): Stimulatory beetle Volatiles for the Asian Longhorned Beetle, Anoplophora glabripennis (Moschulsky). In: Zeitschrift für Naturforschung C (57(6-6)), S. 553-558. 


\section{Part I: Investigation of volatile organic compounds emitted by Anoplophora glabripennis (Moschulsky) by using thermal desorption and gas chromatography-mass spectrometry}

Makarow, Ramona'; Schaefer, Sara'; Albrecht Stephan', Robert, Simon', Schütz, Stefan², Kaul, Peter'

'Safety and Security Research Institute, Institute of Detection Technologies, Hochschule Bonn-Rhein-Sieg University of Applied Sciences, von-Liebig-Straße 20, 53359 Rheinbach, Germany

${ }^{2}$ Buesgen-Institute, Georg-August University of Göttingen, Buesgenweg 5, 37077 Göttingen, Germany

This chapter is published in the 'Microchemical Journal ': Microchemical Journal 146 (2019), 142-148; https://doi.org/10.1016/j.microc.2018.12.036

\subsection{ABSTRACT}

Volatile organic compounds (VOCs) from alive Anoplophora glabripennis (ALB) imagines, larvae and ovipositions were obtained by enrichment on adsorbents. They were analysed qualitatively by thermal desorption coupled with gas chromatography and a mass selective detector. Altogether 229 substances were identified: 34 from larvae, 19 from imagines and 176 from ovipositions. Ovipositions of two generations were analysed, both over an 8-week period with focus on ageing and repeatability. (+)- $\alpha$-Longipinene occurred in $100 \%,(+)$-cyclosativene and $\alpha$-cubebene in $99 \%$ of all oviposition measurements. 1R- $\alpha$-Pinene occurred in $100 \%$ of all imago measurements. 2,4-Dimethyl-1-heptene and (+)-cyclosativene were detectable in all three ALB sample types.

Keywords:

Anoplophora glabripennis, volatile organic compounds, TD-GC/MS 


\subsection{INTRODUCTION}

Over the last years, entry of invasive species in Europe has increased constantly. Many cause no impact to native flora and fauna, others do not cause damage, but plenty of them threaten native species and nature. The number of invasive species has increased due to globalization and imports from foreign countries (Schmiedel et al. 2015). For example, the Asian long-horned beetle (Anoplophora glabripennis (Moschulsky), ALB) was first reported in North America in 1996 and Europe in 2001. The larvae are transported to America and Europe via wood packaging material (Haack et al. 1997) (Dr. Doris Hölling 2016). It is listed as one of the most dangerous invasive pests according to the Directive 2000/29/CE. European regulations lay down the approach against infestation in Europe. Monitoring and felling infested and possible host-trees in a $100 \mathrm{~m}$-diameter are the main counter-measures (European Union 2000). A common method to counter the spreading of ALB and to protect trees from felling is the use of pheromone traps. Electroantennographic detection showed that male ALB beetles react significantly to two dialkyl ethers 4-(n-heptyloxy)butanal and 4-(n-heptyloxy)butan-1-ol which are supposed to act as pheromones (Zhang et al. 2002). A third potential pheromone (3E, 6E)- $\alpha$-farnesene that showed better trapping rates was identified (Crook et al. 2014). The addition of the plant volatiles (-)-linalool, (Z)-3-hexen-1-ol, linalool oxide, trans-caryophyllene and trans-pinocarveol to the pheromones also significantly increases trap catches of females (Nehme et al. 2010). Furthermore, Manoukis et al. (Manoukis et al. 2014) show that the average cumulative capture probability after 30 days is between $4 \%$ and approximately $12 \%$, depending on the trap grid and the attractiveness of the lure. These poor rates are due to ALB's distinct tendency to stay within the host tree and the rarity of flight periods and adult emergence. The author suggests alternative detection methods as they may outperform the efficiency of trapping in case of ALB, if the trap attractiveness is low 8 . Alternative detection methods have to be developed or improved.

Recently, sniffer dogs were used for the early state detection of ALB infestations as well as for monitoring. Dogs have been trained for the detection of ALB since 2009 (Hoyer-Tomiczek und Sauseng 2009). For this purpose, different kinds of scent materials are used: dead larvae and beetles, spans and wood that once had been infested. Due to strict regulations, living material such as living larvae or beetles are rarely used despite the fact that living material most likely contains all substances relevant for ALB detection concerning the odour. Dead biological material is subject to degenerative changes, which may cause changes in the scent impression. There are currently no investigations available for the degeneration of ALB beetles or larvae.

Neither are any determinations of volatile organic compounds (VOCs) of alive ALB available yet. The knowledge of VOCs that are emitted by ALB living material and evident for a specific ALB odour is necessary to figure out changes in the scent composition, to improve the work with sniffer dogs and to develop new detection technologies.

The ALB will be an ongoing problem in the future as there are currently at least 21 infestation areas in Europe 3. For the reason described above, it is evident that there is a great need for rapid methods of analysis to counter the spreading of the ALB and to protect trees from felling. Sensing techniques have to 
be based on the volatiles emitted by ALB in its different developmental stages. The knowledge of ALB specific volatiles is a precondition to develop new detection technologies and to improve available detectors like sniffer dogs. The dogs' conditioning and handling will benefit by specifying the training aids to only some relevant volatiles. That may also improve sniffer dogs' selectivity. To determine the VOCs emitted by ALB, larvae, imago and ovipositions were analysed in this paper. A method for thermal desorption gas chromatography-mass spectrometry (TD-GC/MS) has been developed that encloses an enrichment step on adsorption material.

\subsection{Materials AND Methods}

\subsubsection{Chemicals and adsorbent material}

For the conditioning of the adsorbents tubes, acetone of HPLC grade (Rotisolve ${ }^{\circledR}$, Carl Roth Gmbh+ Co KG, Germany) was used. The water was self-purified by a MilliQ® System. For the enrichment, Tenax® TA (mesh 60/80) and Tenax® GR (mesh 20/35) (Alltech Associates Inc.; Buchem BV (Netherlands)) and Carbotrap ${ }^{\circledR}$ (mesh 20/40) (Supelco Inc.; Büchel) and silanized glass wool (Sigma Aldrich (Germany)) were used. For tubing Tygon $®$ tubes (Carl Roth $\mathrm{GmbH}+$ Co KG (Germany)) were used. The Nalophan $®$ foil from Kalle GmbH (Germany) was used for wrapping.

\subsubsection{Instruments}

The chromatographic analysis was performed using a 7890A/5975C inert XN MSD GC/MS device (Agilent Technologies) coupled to a thermal desorption unit from Gerstel. The GC was equipped with a DB5-MS capillary column from J\&W (30 m x 0.250 mm; 0.25 micron). Helium 5.0 was used as carrier gas and the inlet pressure was 9.1473 psi, which corresponds to a flow of $1.2 \mathrm{ml} / \mathrm{min}$.

\section{Chromatographic analysis}

The GC temperature program was held for 2 minutes at $35^{\circ} \mathrm{C}$, then increased to $170^{\circ} \mathrm{C}$ at $8{ }^{\circ} \mathrm{C} / \mathrm{min}$, then to $240{ }^{\circ} \mathrm{C}$ at $60{ }^{\circ} \mathrm{C} / \mathrm{min}$ and finally held for 2 minutes. Analysis was carried out with a 1:15 split. Liner temperature was kept to $250^{\circ} \mathrm{C}$.

The Cold Injection System (CIS) was cooled to $-120^{\circ} \mathrm{C}$ then heated to $250{ }^{\circ} \mathrm{C}$ at $12{ }^{\circ} \mathrm{C} / \mathrm{min}$ and held for 3 minutes. The thermodesorption unit had an initial temperature of $30^{\circ} \mathrm{C}$ and was heated to $230{ }^{\circ} \mathrm{C}$ at $40^{\circ} \mathrm{C} / \mathrm{min}$ and held for 1 minute. The transfer temperature was $240^{\circ} \mathrm{C}$. The desorption mode was splitless. All together the whole TD/GC-analysis was carried out with a 1:15 split.

The complete desorption of VOCs by the method with TDU was tested by double analysis of some samples. The double analysis was performed in five-time repetitions as part of the development of the analytical method and randomly during the sample analysis stage. The second analysis led to the same results as blanks. Thus it can be assumed that the method leads to a total desorption of the analytes from the adsorbents. 
The mass spectra were recorded in the electron-impact mode $(70 \mathrm{eV})$ from 30 to $400 \mathrm{u}$. Each peak in the chromatogram was identified by comparing the fragmentation pattern typical of each compound to the National Institute of Standards and Technology (NIST) 5.0 database. Only substances with a minimum of $80 \%$ match and reproducible retention times in at least three measurements were considered as unambiguous substance identification.

\subsubsection{Analytical Method Development and sampling optimisation}

Glass tubes $(6.0 \mathrm{~cm} \times 0.5 \mathrm{~cm}$ ), were filled with $120 \mathrm{mg}$ of the adsorbents Tenax® TA or Tenax® GR, or $150 \mathrm{mg}$ of Carbotrap $\circledast$ fixed in place by glass wool. Freshly filled adsorbent tubes were conditioned once by five-times elution with an acetone/water (90/10) solution, drying at $50{ }^{\circ} \mathrm{C}$ for $24 \mathrm{~h}$ and placing them three times into an oven at $280^{\circ} \mathrm{C}$, each for $1 \mathrm{~h}$, while carbon filtered $\mathrm{N}_{2}$ (5.0) of constant flow was transferred through the tubes. For reconditioning, tubes were placed into an oven at $280^{\circ} \mathrm{C}$ for $1 \mathrm{~h}$ while carbon filtered $\mathrm{N}_{2}$ of constant flow was carried through the tubes. The efficiency of the procedure was controlled by blank analysis.

Tenax $®$ TA, Tenax $®$ GR and Carbotrap $®$ were tested for their efficiency on trapping ALB volatiles. Enrichment duration of the volatiles was 90 minutes and enrichment flow was $30 \mathrm{ml} / \mathrm{min}$. Enrichment took place instantly in a row with the same ALB larva for all comparisons (see Figure 4). Carbotrap $₫$ led to less trapped substances compared to Tenax® TA. In particular, substances from the group of aromatics and sesquiterpenes were not measurable on Carbotrap ${ }^{\circledR}$. Altogether, 6 substances were measurable on Carbotrap and 20 on Tenax® TA. Tenax® TA and Tenax® GR showed comparable results. Thus Tenax® TA and Tenax $®$ GR were used for the enrichment of volatiles for the measurements in this paper.

\subsubsection{Sampling procedures}

Alive ALB beetles and larvae were put into a $20 \mathrm{ml}$ headspace glass vial for the duration of the enrichment of the VOCs on adsorbents. Two small cuts in the septum were used for the enrichment, whereas the pump was adjusted at one hole so that the ambient air was carried over the ALB sample onto the adsorbents tube (Figure 4).

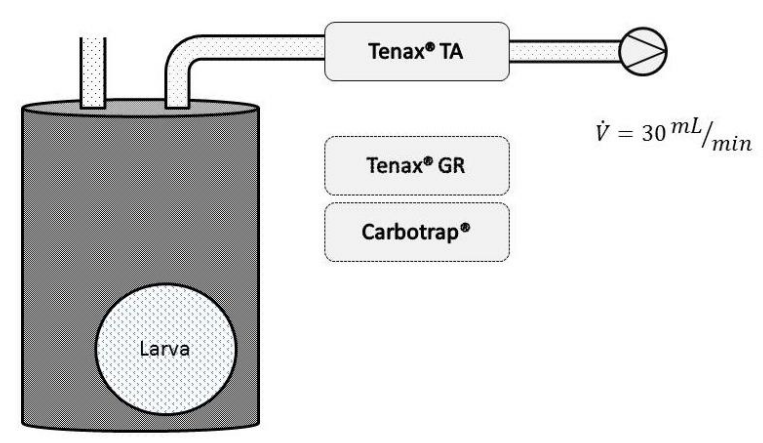

Figure 4: Schema of the sampling procedure for the comparison of the trapping efficiency of Tenax $®$ TA, Tenax $®$ GR and Carbotrap $\circledast$. The vital larva was put into a $20 \mathrm{ml}$ headspace-vial closed with an aluminium cap with septum. Two tubes were inserted through the septum. 
ALB ovipositions were analysed directly on the trunk. Therefore, a segment of approximately 10 to $20 \mathrm{~cm}$ of the trunk, that encompasses the ovipositions, was wrapped with Nalophan® foil. Based on Rachow's descriptions (Rachow et al. 2012), an enrichment method was developed that forgoes the use of tape and works with newly designed adapters between the foil and the sampling tubes. The foil is food-safe and therefore has very low emissions of VVOCs and VOCs. The headspace analysis of the foil did not show any peaks in the chromatogram. The foil was closed by staples. The top and bottom of the foil were closed by foam padded lashing straps. An aluminium adaptor was developed and adjusted on the foil, so that air from the inside of the foil was pumped onto the adsorbents tube. Originally Rachow et al. used medical tape instead of staples to close the foil. The headspace analysis of the tape showed numerous peaks in the chromatogram that interfere the measurements. Therefore, the tape was replaced.

Volatile enrichment on adsorption material took place at the plant protection service of North RhineWestphalia (PPS) inside the quarantine facilities for ALB breeding. Enrichment time was 90 minutes; flow rate was $30 \mathrm{ml} / \mathrm{min}$. Pumps of two different types were used namely Gilian GilAir Plus and Gilian LFP-113DC Low Flow Sampler. The flow for the Gilian LFP was adjusted by the Analyt-MTC mass-flow-meter (AnalytMTC Messtechnik GmbH, Germany). After the enrichment, the adsorbent tubes were immediately stored at $-18^{\circ} \mathrm{C}$ in a mobile freezer for a maximum of $24 \mathrm{~h}$. Afterwards, the tubes were analysed by TD-GC/MS.

\subsubsection{ALB samples}

All larvae originate from an open land infestation in Magdeburg (Sachsen-Anhalt, Germany). Three different larvae were analysed; all were in a similar stage of development. They had a length of approximately $5 \mathrm{~cm}$ each with a thickness of about $1 \mathrm{~cm}$ in diameter. They were already quite inactive and suggested to pupate soon. Adult ALB beetles, male and female, were obtained from the PPS in Bonn.

\begin{tabular}{|c|c|c|c|}
\hline & Description & Collection method & No.(measurements) \\
\hline 1 & ALB Larva & Enclosed in glass vial, adsorption on Tenax $\mathbb{R}$ TA & 22 \\
\hline 2 & ALB Adult & 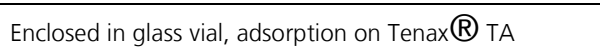 & 13 \\
\hline 3 & $\begin{array}{l}\text { ALB Oviposition } \\
\text { (P1 generation) }\end{array}$ & 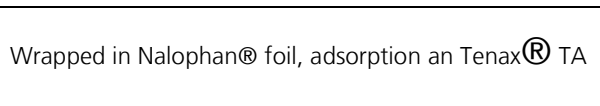 & 27 \\
\hline 4 & $\begin{array}{l}\text { ALB Oviposition } \\
\text { (P2 generation) }\end{array}$ & Wrapped in Nalophan® foil, adsorption an Tenax $®$ TA & 59 \\
\hline
\end{tabular}

The ALB imagines were about eight weeks old and emerged from Acer in the quarantine facilities. Ovipositions were measured from two different breeds (named P1 and P2), both on Acer and both in the quarantine facilities. P2 was analysed one year after P1 (see Supplements). Measurements took place over an eight-week period, whereas ovipositions were analysed once a week with 4 to 8 repetitions per day. All sample types and the used collection methods are shown in Table 4. 


\subsection{RESULTS}

The results of the analysis of ALB imago, larva and oviposition are given in Table 5, Table 6 and in the Supplements. The tables show a list of substances (name and CAS number) measured sorted by class (hydrocarbons, benzoic substances, monoterpenes and sesquiterpenes). The crosses indicate the occurrence of the substance per samples. The tables also show the rate of occurrence among all samples, absolute and relative. A summary of the substances that occur at least in $50 \%$ of all measurements per sample for all sample types is given in Table 8 .

The substances copaene and $\alpha$-cubebene are listed as one substance, due to very high similarity especially in the mass spectrum. Neither distinction via MS nor by use of standards was possible, because standards for these sesquiterpenes were not available at all. The occurrence and overlay of both substances is also possible.

\subsubsection{ALB Imagines}

The analysis of two ALB imagines-one male, one female-in 13 measurements shows 19 substances: 12 hydrocarbons, 4 monoterpenes, 3 sesquiterpenes and no aromatic compounds (see Table 5). The monoterpene $\alpha$-Pinene showed up in every measurement, the three branched hydrocarbons 2,4-dimethyl-heptane, 2,4-dimethyl-heptene and 4-methyl-decane in almost $70 \%$ of all measurements. Together with the sesquiterpene caryophyllene, these five substances occur in at least half of all measurements.

Table 5: List of substances determined from a TD-GC/MS analysis from ALB imagines: one male beetle ('A') and one female beetle ('B'). Substances are sorted by class (HC hydrocarbons, MT monoterpenes, ST sesquiterpenes) and rate ('total no. of 13')

\begin{tabular}{|c|c|c|c|c|c|c|c|c|c|c|c|c|c|c|c|c|c|c|}
\hline \multirow[b]{2}{*}{ no. } & \multirow[b]{2}{*}{ class } & \multirow[b]{2}{*}{ CAS } & \multirow[b]{2}{*}{ Substance } & \multicolumn{3}{|c|}{ A } & \multicolumn{3}{|c|}{ B } & \multicolumn{3}{|c|}{ B } & \multicolumn{4}{|c|}{ B } & \multirow{2}{*}{$\begin{array}{c}\text { total } \\
\text { no. } \\
\text { of } 13\end{array}$} & \multirow{2}{*}{ rel. } \\
\hline & & & & 1 & 2 & 3 & 1 & 2 & 3 & 1 & 2 & 3 & 1 & 2 & 3 & 4 & & \\
\hline 1 & $\mathrm{HC}$ & $2213-23-2$ & 2,4-Dimethyl-Heptane & $x$ & $x$ & $x$ & $x$ & $x$ & $x$ & & $x$ & $x$ & & $x$ & & & 9 & $69 \%$ \\
\hline 2 & $\mathrm{HC}$ & $19549-87-2$ & 2,4-Dimethyl-1-Heptene & $x$ & $x$ & $x$ & $x$ & & & $x$ & $x$ & $x$ & $x$ & $x$ & & & 9 & $69 \%$ \\
\hline 3 & $\mathrm{HC}$ & $2847-72-5$ & 4-Methyl-Decane & $x$ & $x$ & $x$ & $x$ & & & & $x$ & $x$ & $x$ & $x$ & $x$ & & 9 & $69 \%$ \\
\hline 4 & $\mathrm{HC}$ & $112-40-3$ & Dodecane & $x$ & $x$ & $x$ & & & & $x$ & & $x$ & $x$ & $x$ & & $x$ & 8 & $62 \%$ \\
\hline 5 & $\mathrm{HC}$ & $2216-34-4$ & 4-Methyl-Octane & $x$ & $x$ & $x$ & $x$ & & & $x$ & & $x$ & $x$ & & & & 7 & $54 \%$ \\
\hline 6 & $\mathrm{HC}$ & $17312-53-7$ & 3,6-Dimethyl-Decane & $x$ & $x$ & $x$ & $x$ & & & & & & & & & & 4 & $31 \%$ \\
\hline 7 & $\mathrm{HC}$ & $565-75-3$ & 2,3,4-Trimethyl-Pentane & & & & $x$ & $x$ & & & & & $x$ & & & & 3 & $23 \%$ \\
\hline 8 & $\mathrm{HC}$ & $17312-53-7$ & 3,6-Dimethyl-Decane & $x$ & & $x$ & $x$ & & & & & & & & & & 3 & $23 \%$ \\
\hline 9 & $\mathrm{HC}$ & $17312-53-7$ & 3-6-Dimethyl-Decane & & $x$ & & & & & & $x$ & & & & & $x$ & 3 & $23 \%$ \\
\hline 10 & $\mathrm{HC}$ & $17312-82-2$ & 4,6-Dimethyl-Undecane & $x$ & $x$ & & & & $x$ & & & & & & & & 3 & $23 \%$ \\
\hline 11 & $\mathrm{HC}$ & $17301-30-3$ & 3,8-Dimethyl-Undecane & & & $x$ & $x$ & & & & & & & $x$ & & & 3 & $23 \%$ \\
\hline 12 & $\mathrm{HC}$ & $629-62-9$ & & $x$ & $x$ & & & & $x$ & & & & & & & & 3 & $23 \%$ \\
\hline 13 & MT & $7785-70-8$ & 1R- $\alpha$-Pinene & $x$ & $x$ & $x$ & $x$ & $x$ & $x$ & $x$ & $x$ & $x$ & $x$ & $x$ & $x$ & $x$ & 13 & $100 \%$ \\
\hline 14 & MT & $13466-78-9$ & 3-Carene & $x$ & $x$ & $x$ & $x$ & $x$ & $x$ & $x$ & & & & & & & 7 & $54 \%$ \\
\hline 15 & MT & $80-56-8$ & $\alpha$-Pinene & $x$ & & & & & $x$ & $x$ & & $x$ & $x$ & $x$ & & & 6 & $46 \%$ \\
\hline 16 & MT & $127-91-3$ & $\beta$-Pinene & & & & $x$ & $x$ & $x$ & & & $x$ & $x$ & & & & 5 & $38 \%$ \\
\hline 17 & ST & $87-44-5$ & Caryophyllene & & & $x$ & $x$ & $x$ & $x$ & & & $x$ & $x$ & & $x$ & $x$ & 8 & $62 \%$ \\
\hline 18 & ST & $13744-15-5$ & $\beta$-Cubebene & & & & & $x$ & $x$ & & & & & & $x$ & $x$ & 4 & $31 \%$ \\
\hline 19 & ST & 22469-52-9 & (+)-Cyclosativene & & & & $x$ & $x$ & $x$ & & & & & & & & 3 & $23 \%$ \\
\hline
\end{tabular}




\subsubsection{ALB Larvae}

The analysis of 3 different larvae in altogether 22 measurements showed the occurrence of 34 substances. 5 substances can be detected in at least half of the measurements. Three of them are terpenes (limonene, (+)-cyclosativene, cubebene); the other two are hydrocarbons (2,4-dimethyl-heptene, dodecane). The composition of VOCs from ALB larvae sorted as hydrocarbons, benzenes, monoterpenes and sesquiterpenes is shown in Table 6. 


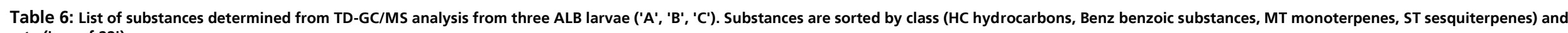
rate ('no. of 22')

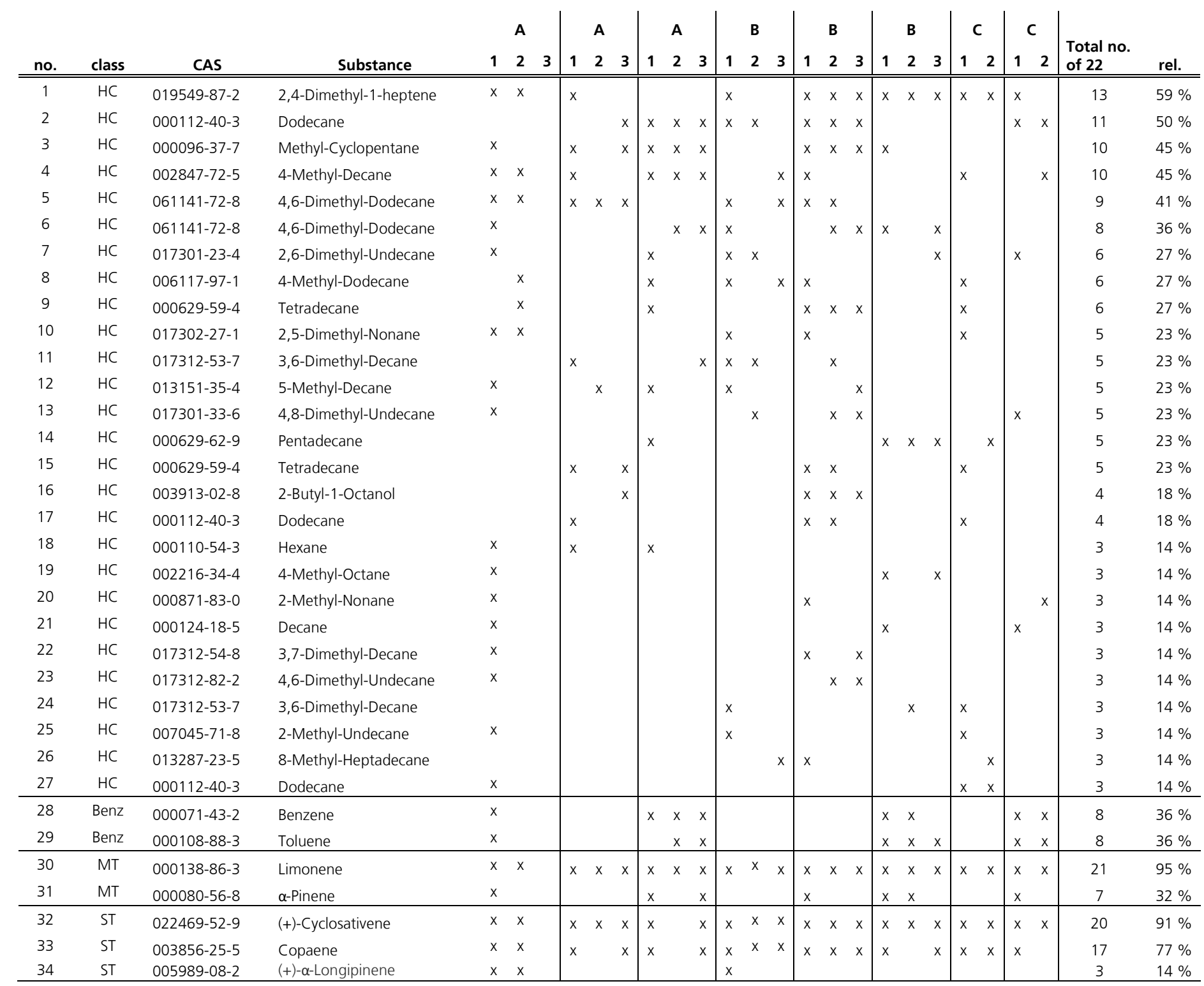




\subsubsection{ALB Oviposition}

In the first generation of ovipositions (P1) 80 substances were determined: 34 hydrocarbons, 22 benzoic, 8 monoterpenes, 16 sesquiterpenes. Among them, 14 substances were determined in at least $50 \%$ of all 27 measurements: 8 hydrocarbons of which 7 were Alkanes, 2 benzoic substances whereas 2,6-diisonaphthalene occurs at 3 different retention times. With camphene (89\%), $\beta$-ocimene (78 \%), 1R- $\alpha$-pinene (56\%) and 3-carene (52\%), 4 monoterpenes and with (+)- $\alpha$-longipinene (100\%), (+)-cyclosativene, $\alpha$-cubebene, (+)-longifolene, caryophyllene (each $85 \%$ ) and d-curcumene (59 \%), 6 sesquiterpenes occur in more than $50 \%$ of all measurements. Noticeable is the occurrence of 2 sesquiterpenes in early states of oviposition until week 2: zingiberene (week 1 and 2 ) and $\alpha$-caryophyllene (week 1 and 2). The monoterpene (+)-3-carene is only available for very fresh ovipositions (week 1). The total list of substances can be seen in the Supplements.

Table 7: List of substances from TD-GC/MS analysis from ALB ovipositions that occur in both generations. Substances are sorted by class (HC hydrocarbons, Benz benzenes, MT monoterpenes, ST sesquiterpenes) and rate ('total of 86 '). 86 measurements were obtained.

\begin{tabular}{|c|c|c|c|c|c|c|c|}
\hline No. & Class & CAS & Substance & $\begin{array}{c}\text { Total no. } \\
\text { of } 86\end{array}$ & rel. of total, $\%$ & $\begin{array}{c}\text { no. of } \\
\text { P1 (of 27) }\end{array}$ & $\begin{array}{c}\text { no. of } \\
\text { P2 (of 59) }\end{array}$ \\
\hline 1 & $\mathrm{HC}$ & $111-65-9$ & Octane & 47 & $55 \%$ & 25 & 22 \\
\hline 2 & $\mathrm{HC}$ & $112-40-3$ & Dodecane & 32 & $37 \%$ & 16 & 16 \\
\hline 3 & $\mathrm{HC}$ & $629-62-9$ & Pentadecane & 24 & $28 \%$ & 21 & 3 \\
\hline 4 & $\mathrm{HC}$ & $66-25-1$ & Hexanal & 16 & $19 \%$ & 3 & 13 \\
\hline 5 & $\mathrm{HC}$ & $19549-87-2$ & 2,4-Dimethyl-1-heptene & 12 & $14 \%$ & 6 & 6 \\
\hline 6 & $\mathrm{HC}$ & $2847-72-5$ & Decane, 4-methyl- & 12 & $14 \%$ & 5 & 7 \\
\hline 7 & $\mathrm{HC}$ & $565-75-3$ & Pentane, 2,3,4-trimethyl- & 11 & $13 \%$ & 8 & 3 \\
\hline 8 & $\mathrm{HC}$ & $2213-23-2$ & Heptane, 2,4-dimethyl- & 11 & $13 \%$ & 6 & 5 \\
\hline 9 & $\mathrm{HC}$ & $2216-34-4$ & Octane, 4-methyl- & 9 & $10 \%$ & 5 & 4 \\
\hline 10 & $\mathrm{HC}$ & $17302-27-1$ & Nonane, 2,5- dimethyl- & 7 & $8 \%$ & 4 & 3 \\
\hline 11 & $\mathrm{HC}$ & $7045-71-8$ & Undecane, 2-methyl- & 6 & $7 \%$ & 3 & 3 \\
\hline 12 & Benz & $24157-81-1$ & 2,6-Diisopropylnaphthalene & 32 & $37 \%$ & 24 & 8 \\
\hline 13 & Benz & $108-88-3$ & Toluene & 26 & $30 \%$ & 20 & 6 \\
\hline 14 & Benz & $108-67-8$ & Benzene, 1,3,5-trimethyl- & 11 & $13 \%$ & 7 & 4 \\
\hline 15 & MT & $79-92-5$ & Camphene & 83 & $97 \%$ & 24 & 59 \\
\hline 16 & MT & $138-86-3$ & Limonene & 40 & $47 \%$ & 8 & 32 \\
\hline 17 & MT & $13466-78-9$ & 3-Carene & 36 & $42 \%$ & 14 & 22 \\
\hline 18 & MT & $7785-70-8$ & 1R- $\alpha$-Pinene & 32 & $37 \%$ & 15 & 17 \\
\hline 19 & ST & $5989-08-2$ & (+)- $\alpha$-Longipinene & 86 & $100 \%$ & 27 & 59 \\
\hline 20 & ST & $22469-52-9$ & (+)-Cyclosativene & 85 & $99 \%$ & 26 & 59 \\
\hline 21 & ST & $17699-14-8$ & $\alpha$-Cubebene/ Copaene & 85 & $99 \%$ & 26 & 59 \\
\hline 22 & ST & $87-44-5$ & Caryophyllene & 71 & $83 \%$ & 23 & 48 \\
\hline 23 & ST & $495-60-3$ & Zingiberene & 40 & $47 \%$ & 5 & 35 \\
\hline 24 & ST & $489-40-7$ & $\alpha$-Gurjunene & 20 & $23 \%$ & 10 & 10 \\
\hline
\end{tabular}

The repetition of the experiment in the P2 generation showed 50 substances: 22 hydrocarbons, 3 benzoic substances, 9 monoterpenes and 16 sesquiterpenes. Substances that occurred in at least $50 \%$ of the measurements were camphene (100\%), tricyclo[2.2.1.0(2,6)]heptane,1,7,7-trimethyl- (60\%), limonene (53\%), a-longipinene (100\%), (+)-cyclosativene (100\%), a-cubebene (100\%), caryophyllene (82\%), $(-)$-zingiberene (58\%) and ( $\alpha$ )-bergamotene (Table 7). Two substances occur only after some weeks until 
older stages: Z,Z,Z-1,5,9,9-tetramethyl-cycloundecatriene from week 4 and ocimene from week 5 . 2,4-dimethyl-heptene occurs only in the first two weeks after oviposition.

In the supplementary material a list shows all substances that were analysed in both generations of oviposition: 11 hydrocarbons, 3 benzoic substances, 4 monoterpenes and 6 sesquiterpenes. Remarkable is the appearance of $(+)-(\alpha)$-longipinene, $(+)$-cyclosativene, $(\alpha)$-cubebene and camphene in $100 \%, 99 \%$, $99 \%$ and $97 \%$ of all 86 oviposition measurements, respectively. Together with caryophyllene, which occurs in $83 \%$ of all measurements five substances are apparent in more than $80 \%$ of 86 measurements.

\subsection{Discussion}

Oviposition measurements are carried out on tree trunks that emit volatiles themselves and can lead to misinterpretations. In order to exclude the tree as a source of relevant volatiles, measurements on healthy Acer trunks (without ovipositions) were performed in advance and compared to oviposition measurements which were also performed on Acer trunks. Using relevant sesquiterpenes as an example, the measurements show that ovipositions emit significantly more substances than a healthy trunk. In Figure 6 and Figure 7 in the Supplemental material (chapter 2.9), the comparison of infested and healthy Acer and infested and healthy Populus is shown with the focus on relevant sesquiterpenes. Only for Salix is there an emission of copaene/ $\alpha$-cubebene from the healthy trunk as well as from the infested trunk (Figure 5), whereas the peak area and therefore the amount of copaene/a-cubebene is significantly higher on infested Salixes' trunks. No further influences on the trunk were evident.

Substances that occur in every ALB sample type (imago, larva, oviposition) are 2,4-dimethyl-1-heptene and (+)-cyclosativene. For Larva and oviposition (+)-cyclosativene were detected in more than $50 \%$ of all measurements. For ALB imago (+)-cyclosativene was also detectable in three measurements $(23 \%)$. 2,4-dimethyl-1-heptene was in $50 \%$ of all available larva and imago measurements. In ovipositions 2,4-dimethyl-1-heptene is present in 12 of 86 measurements (14\%). A Scifinder Scholar search results in 24 papers, in which 2,4-dimethyl-1-heptene is named in context of 'occurrence'. Most of them deal with volatiles in plastics or wastewater of plastic production. Seven publications name 2,4-dimethyl-1-heptene as a volatile from different plants or algae (Austel et al.) (Balogun et al. 2014) (Chen und Ge 2014) (Cao et al. 2012) (Erakin und Güven 2008) (Sukatar et al. 2006) (Wang et al. 2011) (Ozdemir et al. 2006). No publication was found that named 2,4-dimethyl-1-heptene as a volatile compound of any animal species. (+)-Cyclosativene is usually available in measurements of the volatiles and essential oils of plants. A Scifinder Scholar search reveals 140 references for the occurrence of the substance: 135 of them describe the analysis of plant volatiles, 2 describe analytical methods, one the volatiles of baked potatoes and one is detectable among the volatiles of infested tomatoes (Thelen et al. 2005): Thelen et al. describe $\alpha$-copaene as a specific marker substance for the infected tomatoes. Copaene is also detectable on ALB infested trees as it occurs in oviposition and larva measurements. Among oviposition and larva measurements, copaene occurs in 99 $\%$ and $77 \%$ respectively. As ovipositions are directly on the trunk and larvae nourish from wood, copaene can therefore be a metabolic product of the wooden part of trees. Affirming this conclusion, copaene is not apparent among the ALB imago measurements, nor in measurements on healthy, not infested trunks (see 
Figure 6 and Figure 7). ALB imagines are nourished not from wood but from leaves. To confirm copaene as a specific marker of ALB infested trees, a statistical safe number or replicates is necessary as well as comparative

Table 8: List of substances that occur in at least $50 \%$ of each batch 'Beetle', 'Larva' and 'Oviposition', whereas the latter is subdivided in the two generations and both generations as a sum

\begin{tabular}{|c|c|c|c|}
\hline Sample type & n (substances) & $n$ (substance) $\geq 50 \%$ of all & CAS \\
\hline \multirow{6}{*}{ Beetle } & \multirow{6}{*}{19} & 2,4-Dimethyl-1-Heptene & 19549-87-2 \\
\hline & & 2,4-Dimethyl-Heptane & $2213-23-2$ \\
\hline & & 4-Methyl Decane & $2847-72-5$ \\
\hline & & Dodecane & $112-40-3$ \\
\hline & & Caryophyllene & $87-44-5$ \\
\hline & & 1R- $\alpha$-Pinene & 7785-70-8 \\
\hline \multirow{5}{*}{ Larva } & \multirow{5}{*}{34} & 2,4-Dimethyl-1-Heptene & 19549-87-2 \\
\hline & & Dodecane & $112-40-3$ \\
\hline & & Limonene & $138-86-3$ \\
\hline & & (+)-Cyclosativene & $22469-52-9$ \\
\hline & & Copaene & $3856-25-5$ \\
\hline \multirow{25}{*}{ Oviposition } & \multirow{12}{*}{27} & Octane & $111-65-9$ \\
\hline & & Dodecane & $112-40-3$ \\
\hline & & Pentadecane & $629-62-9$ \\
\hline & & 2,6-Diisopropylnaphthalene & 24157-81-1 \\
\hline & & Toluene & $108-88-3$ \\
\hline & & Camphene & $79-92-5$ \\
\hline & & 3-Carene & $13466-78-9$ \\
\hline & & 1R- $\alpha$-Pinene & $7785-70-8$ \\
\hline & & (+)- $\alpha$-Longipinene & 5989-08-02 \\
\hline & & (+)-Cyclosativene & $22469-52-9$ \\
\hline & & Copaene & 19699-14-8 \\
\hline & & Caryophyllene & $87-44-5$ \\
\hline & \multirow{7}{*}{59} & Camphene & $79-92-5$ \\
\hline & & Limonene & $138-86-3$ \\
\hline & & (+)- $\alpha$-Longipinene & 5989-08-02 \\
\hline & & (+)-Cyclosativene & $22469-52-9$ \\
\hline & & Copaene & $17699-14-8$ \\
\hline & & Caryophyllene & $87-44-5$ \\
\hline & & Zingiberene & $495-60-3$ \\
\hline & \multirow{6}{*}{86} & Octane & $111-65-9$ \\
\hline & & Camphene & $79-92-5$ \\
\hline & & (+)- $\alpha$-Longipinene & 5989-08-02 \\
\hline & & (+)-Cyclosativene & $22469-52-9$ \\
\hline & & $\alpha$-Cubebene/ Copaene & $17699-14-8$ \\
\hline & & Caryophyllene & $87-44-5$ \\
\hline
\end{tabular}

measurements to other species. It is conceivable that copaene in combination with (+)-cyclosativene and 2,4-dimethyl-1-heptene or further/other additional substances form a chemical mixture of volatiles, that is a specific hint to ALB infestation. Particularly as (+)-cyclosativene and 2,4-dimethyl-1-heptene have not yet been identified as volatiles emitted by insects. 


\subsection{CONCLUSION}

The intended scope of the paper was to develop a method for the analysis of volatiles emitted by ALB larvae, imagines and ovipositions. There was a focus on the enrichment step to collect all relevant volatiles. There were no preliminary investigations of ALB's gaseous emissions. The enrichment on Tenax $®$ TA is an appropriate method to determine the volatiles of larvae, imagines and ovipositions. Altogether, 229 substances were found. Despite biological variance among different samples of e.g. ovipositions, there was an occurrence of $(+)$ - $\alpha$-longipinene in $100 \%,(+)$-cyclosativene and copaene/ $\alpha$-cubebene in $99 \%$ of all oviposition measurements.

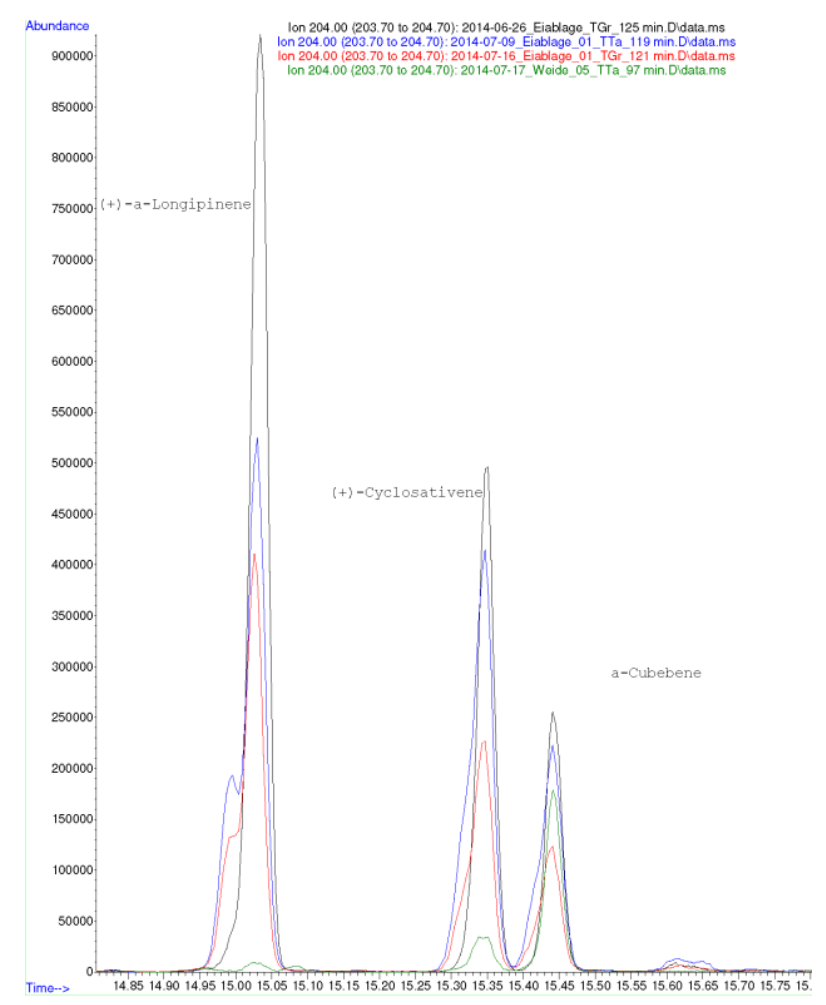

Figure 5: Overlay of chromatograms: in black, blue and red trunk with ALB ovipositions on Acer, in green healthy trunk of Salix

That points out the reliable availability of some volatiles in ambient air and therefore the fulfilment of a fundamental requirement for the use of detection systems. This work is the first step towards the improvement of detection systems for an ALB investigation. The next steps will be to distinguish between invasive and native beetles like Saperda carcharias or Zeuzera pyrina and determine ALB specific airborne volatiles. 


\subsection{ACKNOWLEDGEMENT}

The results were obtained within a funded research project financed by the Ministry for Environment, Agriculture, Conservation and Consumer Protection of the State of North Rhine-Westphalia ('Ministerium für Umwelt, Landwirtschaft, Natur- und Verbraucherschutz des Landes Nordrhein-Westfalen'). It was supported by Gerhard Renker and Dr. Reiner Schrage from the plant protection service in North RhineWestphalia, who managed to build up a ALB breed and supported with entomological expertise. We thank the team of Landesanstalt für Landwirtschaft Sachsen-Anhalt, who offered the larvae.

\subsection{RefERENCES}

Austel, Nadine; Schubert, Jens; Gadau, Sabrina; Jungnickel, Harald; Budnik, Lygia T.; Luch, Andreas: Influence of fumigants on sunflower seeds: Characteristics of fumigant desorption and changes in volatile profiles.

Balogun, S. O.; Oladosu, I. A.; Liu, Zhiqiang (2014): Chemical Compositions and Antioxidant Potential of Essential Oils from Leaves and Flowers of Allophylus africanus. In: Journal of Essential Oil Bearing Plants 17 (5), S. 769-775. DOI: 10.1080/0972060X.2014.895176.

Cao, Yuna; Song, Zhiqian; Zeng, Linyan; Wei, Zheng; Zhang, Linlin; Liu, Zhenli (2012): Comparative analysis of chemical constitutent of Fructus Gerdeniae before and after processing by GC-MS. In: Zhongguo Shiyan Fangjixue Zazhi Bianji Weiyuanhui (Volumen 18), S. 126-129.

Chen, Xiao-kai; Ge, Fa-huan (2014): Chemical components from essential oil of Pandanus amaryllifolius leaves. In: Zhongyaocai (Volumen 37), S. 616-620.

Crook, Damon J.; Lance, David R.; Mastro, Victor C. (2014): Identification of a potential third component of the male-produced pheromone of Anoplophora glabripennis and its effect on behavior. In: Journal of chemical ecology (40), S. 1241-1250. Online verfügbar unter DOI 10.1007/s10886-014-0520-3.

Dr. Doris Hölling (2016): Der Asiatische Laubholzbockkäfer in Europa. WSL, CH. Online verfügbar unter https://www.waldwissen.net/waldwirtschaft/schaden/invasive/wsl_alb_europa/index_DE, zuletzt aktualisiert am 03.10.2016, zuletzt geprüft am 02nd Oct 2019.

Erakin, Sinem; Güven, Kasum Cemal (2008): The volatile petroleum hydrocarbons in marine algae around Turkish coasts. In: Acta Pharmaceutica Sciencia (50), S. 167-182.

European Union (2000): Council Directive 2000/29/EC, vom of May 2000. In: Official Journal of the European Communities (169), S. 1-112. Online verfügbar unter https://eur-lex.europa.eu/legalcontent/EN/ALL/?uri=CELEX\%3A32000L0029, zuletzt geprüft am 06.12.2019.

Haack, Robert A.; Law, Kenneth R.; Ossenbruggen, H. Sharon; Raimo, Bernard J. (1997): New York's battle with the Asian Lang-Horned Beetle. In: Journal of Forestry (95), S. 11-15.

Hoyer-Tomiczek, Ute; Sauseng, Gabriele (2009): Spürhunde erschnüffeln Quarantäneschädling ALB und CLB. In: Forstschutz aktuell (48), S. 1-4. 
Manoukis, Nicholas C.; Hall, Brian; Geib, Scott M. (2014): A computer model of insect traps in a landscape. In: Scientific reports 4, S. 7015. DOI: 10.1038/srep07015.

Nehme, M. E.; Kenna, M. A.; Zhang, A.; Baker, T. C.; Xu, Z.; Hoover, K. (2010): Evaluating the use if maleproduced pheromone components and plant volatiles in two trap designs to monitor Anoplophora glabripennis. In: Environmental entomology (Vol. 39), S. 169-176. Online verfügbar unter DOI:10.1603/EN09177.

Ozdemir, Guven; Horzum, Zerrin; Sukatar, Atakan; Karabay-Yavasoglu, N. Ulku (2006): Antimicrobial activities of volatile components and various extracts of Dictyopteris membranaceae and Cystoseira barbata. from the Coast of Izmir, Turkey. In: Pharmaceutical Biology (44), S. 183-188. Online verfügbar unter DOI: 10.1080/13880200600685949.

Rachow, Christine; Gester-Gerstmann, Patrik; Weis, Björn; Schütz, Stefan (2012): Ein neues VErfahren zum Sammeln von Stammvolatilen. In: Mitt. Dtsch. Ges. Allg. Angew. Ent. (18), S. 635-639.

Schmiedel, Doreen; Wilhelm, Eckehard-G.; Nehring, Stefan; Scheibner, Cornelia; Roth, Mechthild; Winter, Susanne (2015): Band 1: Pilze, Niedere Pflanzen und Gefäßpflanzen. In: Bundesamt für Naturschutz (Hg.): Management-Handbuch zum Umgang mit gebietsfremden Arten in Deutschland, Bd. 1. Bonn-Bad Godesberg (Pilze, Niedere Pflanzen und Gefäßpflanzen, 1), S. 1-709.

Sukatar, Atakan; Karabay-Yavasoglu, Ulku; Ozdemir, Guven; Horzum, Zerrin (2006): Antimicrobial activity of volatile component and various extracts of Enteromorpha linza (Linnaeus) J. Agardh from the coast of Izmir, Turkey. In: Annals of Microbiology (56), S. 275-279. Online verfügbar unter DOI:10.1007/BF03175018.

Thelen, John; Harbinson, Jeremy; Jansen, Roel; van Straten, Gerrit; Posthumus, Maarten A.; Woltering, Ernst J.; Bouwmeester, H. J. (2005): The sequiterpene alpha-copaene is induced in tomato leaves infected by Botrytis cinerea. In: Journal of Plant Interactions (1), S. 163-170. Online verfügbar unter doi:10.1080/17429140600968177.

Wang, Bin; Yang, Bin; Mu, Xin; Yang, Tianming (2011): Analysis of volatile components of essential oil of Radix Gardeniae jasminoidis by gas chromatigraphy- mass spectroscopy. In: Huaxue Yu Shengwu Gongcheng (28), S. 84-87. Online verfügbar unter DOI:10.3969/j.issn.1672-5425.2011.08.023.

Zhang, Aijun; Oliver, James E.; Aldrich, Jeffrey R.; Wang, Baode; Mastro, Vic C. (2002): Stimulatory Beetle Volatiles for the Asian Longhorned Beetle, Anoplphora glabripennis (Motschulsky). In: Zeitschrift für Naturforschung C (Volumen 57), S. 553-558. Online verfügbar unter DOI:10.1515/znc-2002-5-626. 


\section{Authors' contribution:}

Ramona Makarow wrote this paper, acquired the data of the second generation of ovipositions, developed the method including all optimisation steps and supervised all the authors' data acquisition.

Sara Schäfer determined the first generation of ovipositions in her Master Thesis. The thesis was supervised by R. Makarow. Her acquired data was examined and analysed for this publication by the first author. The chromatographic figures (Figure 5, Figure 6 and Figure 7) were acquired by Sara Schäfer during her Master Thesis work.

Stephan Albrecht determined the VOCs from ALB larvae during his Bachelor Thesis. The thesis was supervised by the first author. The acquired data was examined and analysed for this publication by the first author

Robert Simon determined the VOCs from ALB imagines during his Bachelor Thesis. The thesis was supervised by the first author. The acquired data was examined and analysed for this publication by the first author.

Stefan Schütz and Peter Kaul were the supervisors of the first authors overall work. The structure of this paper was schematically discussed and enhanced with their ideas and input. 


\subsection{SUPPLEMENTAL MATERIAL}

This chapter contents the complete data of the two generations of ALB oviposition measurements and two more figures that show the chromatograms of healthy trunks of Acer and Populus in comparison with trunks and ALB ovipositions for some relevant sesquiterpenes. 


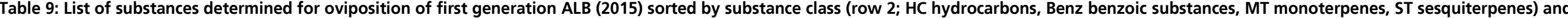
rate in total of 27 measurements (row 'total no. of 27') and relative (row 'rel., \%')

\begin{tabular}{|c|c|c|c|c|c|c|c|c|c|c|c|c|c|c|c|c|c|c|c|c|c|c|c|c|c|c|c|c|c|c|c|c|}
\hline \multirow{2}{*}{\multicolumn{2}{|c|}{ No. }} & \multirow[b]{2}{*}{ CAS } & \multirow[b]{2}{*}{ Substance } & \multicolumn{4}{|c|}{ week 0} & \multicolumn{3}{|c|}{ week 1} & \multicolumn{5}{|c|}{ week 3} & \multicolumn{5}{|c|}{ week 4} & \multicolumn{5}{|c|}{ week 6} & \multicolumn{5}{|c|}{ ।. । - week 8} & \multirow{2}{*}{\begin{tabular}{|c|} 
total \\
no. \\
of \\
27 \\
\end{tabular}} & \multirow[b]{2}{*}{$\begin{array}{l}\text { Rel., } \\
\%\end{array}$} \\
\hline & & & & $\begin{array}{l}\text { A- } \\
\text { I }\end{array}$ & $\begin{array}{l}\text { A- } \\
\text { II }\end{array}$ & $\begin{array}{l}\text { B- } \\
\text { I }\end{array}$ & $\begin{array}{l}\text { B- } \\
\text { II }\end{array}$ & $\begin{array}{l}\text { C- } \\
\text { I }\end{array}$ & C-II & C-III & D & \begin{tabular}{|l} 
E- \\
1
\end{tabular} & E-II & $\begin{array}{l}\text { F- } \\
\text { I }\end{array}$ & $\begin{array}{l}\text { F- } \\
\text { II }\end{array}$ & $\begin{array}{l}\text { G- } \\
1\end{array}$ & $\begin{array}{l}\text { G- } \\
\text { II }\end{array}$ & $\begin{array}{l}\text { G- } \\
\text { III }\end{array}$ & $\begin{array}{l}\text { G- } \\
\text { IV }\end{array}$ & $\begin{array}{l}\text { G- } \\
\text { V }\end{array}$ & $\begin{array}{l}\mathrm{H}- \\
\mathrm{I}- \\
\end{array}$ & $\begin{array}{ll}\mathrm{H}- \\
\mathrm{II}\end{array}$ & $\begin{array}{ll}\mathrm{H}- & \mathrm{H} \\
\mathrm{III} & \mathrm{II} \\
\end{array}$ & $\begin{array}{l}\mathrm{H}- \\
\text { IV }\end{array}$ & \begin{tabular}{|l}
$\mathrm{H}-$ \\
$\mathrm{V}$
\end{tabular} & $\begin{array}{ll}1- & 1 \\
1 & 1 \\
\end{array}$ & $\begin{array}{l}\text { I- } \\
\text { II }\end{array}$ & I-III & I-IV & $\mathrm{I}-\mathrm{V}$ & & \\
\hline 1 & $\mathrm{HC}$ & $111-65-9$ & Octane & $\mathrm{x}$ & $\mathrm{x}$ & $\mathrm{x}$ & $\mathrm{x}$ & $\mathrm{x}$ & $x$ & $\mathrm{x}$ & $\mathrm{x}$ & $\mathrm{x}$ & $\mathrm{x}$ & $\mathrm{x}$ & $\mathrm{x}$ & $\mathrm{x}$ & $\mathrm{x}$ & & $\mathrm{x}$ & & $\mathrm{x}$ & $x \times$ & $x$ & $\mathrm{x}$ & $x$ & $x \times$ & $x$ & $\mathrm{x}$ & $\mathrm{x}$ & $\mathrm{x}$ & 25 & 93 \\
\hline 2 & $\mathrm{HC}$ & $544-76-3$ & Hexadecane & & & $x$ & & $x$ & & $x$ & $\mathrm{x}$ & $\mathrm{x}$ & $\mathrm{x}$ & $\mathrm{x}$ & $\mathrm{x}$ & $x$ & $\mathrm{x}$ & $x$ & $\mathrm{x}$ & $x$ & $x$ & $x \quad x$ & $x$ & $x$ & $x$ & $x \quad x$ & $x$ & $x$ & $\mathrm{x}$ & $\mathrm{x}$ & 23 & 85 \\
\hline 3 & $\mathrm{HC}$ & $629-62-9$ & Pentadecane & $\mathrm{x}$ & $\mathrm{x}$ & & $\mathrm{x}$ & $\mathrm{x}$ & $\mathrm{x}$ & $\mathrm{x}$ & $\mathrm{x}$ & $\mathrm{x}$ & $\mathrm{x}$ & $\mathrm{x}$ & $\mathrm{x}$ & $\mathrm{x}$ & $x$ & & $\mathrm{x}$ & & $\mathrm{x}$ & $\mathrm{x}$ & $\mathrm{x}$ & $\mathrm{x}$ & 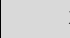 & $x \times$ & $x$ & . & $\mathrm{x}$ & $\mathrm{x}$ & 21 & 78 \\
\hline 4 & $\mathrm{HC}$ & $816-19-3$ & Hexanoic acid, 2-ethyl-, methyl-ester & $\mathrm{x}$ & $x$ & $\mathrm{x}$ & $\mathrm{x}$ & $\mathrm{x}$ & $x$ & $\mathrm{x}$ & $\mathrm{x}$ & $x$ & $\mathrm{x}$ & 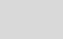 & 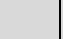 & . & & 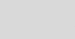 & $\mathrm{x}$ & $\mathrm{x}$ & $\mathrm{x}$ & $x \quad x$ & $\mathrm{x}$ & $\mathrm{x}$ & $x$ & 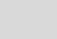 & . & $\mathrm{x}$ & $x$ & & 19 & 70 \\
\hline 5 & $\mathrm{HC}$ & $629-59-4$ & Tetradecane & $\mathrm{x}$ & $x$ & & $x$ & $\mathrm{x}$ & & $x$ & & $\mathrm{x}$ & $x$ & $\mathrm{x}$ & $x$ & $x$ & $x$ & ( & $x$ & $x$ & & 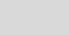 & $\mathrm{x}$ & $\mathrm{x}$ & $x$ & $x \quad x$ & $x$ & $\mathrm{x}$ & $\mathrm{x}$ & & 19 & 70 \\
\hline 6 & $\mathrm{HC}$ & $629-78-7$ & Heptadecane & 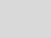 & $\mathrm{x}$ & & & $x$ & $x$ & . & $\mathrm{x}$ & $x$ & & $\mathrm{x}$ & 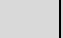 & $\mathrm{x}$ & $x$ & & . & $\mathrm{x}$ & $\mathrm{x}$ & $x \quad x$ & $x$ & $\mathrm{x}$ & $x$ & & $x$ & $\mathrm{x}$ & $\mathrm{x}$ & $\mathrm{x}$ & 18 & 67 \\
\hline 7 & $\mathrm{HC}$ & $112-40-3$ & Dodecane & $x$ & $x$ & $\mathrm{x}$ & $x$ & $\mathrm{x}$ & & $\mathrm{x}$ & $\mathrm{x}$ & $\mathrm{x}$ & $x$ & $\mathrm{x}$ & $x$ & $\mathrm{x}$ & $\mathrm{x}$ & $\mathrm{x}$ & $\mathrm{x}$ & $x$ & & & & & & & & & & & 16 & 59 \\
\hline 8 & $\mathrm{HC}$ & $124-19-6$ & Nonanal & & & & & $\mathrm{x}$ & $x$ & $\mathrm{x}$ & - & $\mathrm{x}$ & $\mathrm{x}$ & $\mathrm{x}$ & $\mathrm{x}$ & $\mathrm{x}$ & $\mathrm{x}$ & $\mathrm{x}$ & $\mathrm{x}$ & & & & & & & $x \times$ & $x$ & & & $\mathrm{x}$ & 14 & 52 \\
\hline 9 & $\mathrm{HC}$ & $593-45-3$ & Octadecane & & & & & & & & $x$ & & & & & $\mathrm{x}$ & & & & $\mathrm{x}$ & $x$ & $x \quad x$ & $x$ & $x$ & $x$ & $x \times$ & $x$ & $x$ & $\mathrm{x}$ & & 12 & 44 \\
\hline 10 & $\mathrm{HC}$ & $108-87-2$ & Cyclohexane, methyl- & $\mathrm{x}$ & $\mathrm{x}$ & $\mathrm{x}$ & & & $x$ & $x$ & $\mathrm{x}$ & $\mathrm{x}$ & & $\mathrm{x}$ & & & $\mathrm{x}$ & $\mathrm{x}$ & & & & & & & & & & & & & 10 & 37 \\
\hline 11 & $\mathrm{HC}$ & $565-75-3$ & Pentane, 2,3,4-trimethyl- & & & & $x$ & $x$ & & & $\mathrm{x}$ & & & & & & $x$ & & & & & & & & & $x \quad x$ & $x$ & $\mathrm{x}$ & & $\mathrm{x}$ & 8 & 30 \\
\hline 12 & $\mathrm{HC}$ & $111-84-2$ & Nonane & $x$ & $x$ & $\mathrm{x}$ & $x$ & & $x$ & $x$ & $\mathrm{x}$ & & & & & & & & & & & & & & & & & $\mathrm{x}$ & & & 8 & 30 \\
\hline 13 & $\mathrm{HC}$ & $124-18-5$ & Decane & $x$ & $x$ & $\mathrm{x}$ & $x$ & & $\mathrm{x}$ & $\mathrm{x}$ & $\mathrm{x}$ & & & & & & & & & & & & & & & & & & & & 7 & 26 \\
\hline 14 & $\mathrm{HC}$ & $294-62-2$ & Cyclododecane & & & & & $\mathrm{x}$ & $x$ & $x$ & & & & & & & & & & & $\mathrm{x}$ & $x \quad x$ & $x$ & $\mathrm{x}$ & & & & & & & 7 & 26 \\
\hline 15 & $\mathrm{HC}$ & $142-82-5$ & Heptane & & $\mathrm{x}$ & $\mathrm{x}$ & & $\mathrm{x}$ & $x$ & $\mathrm{x}$ & $\mathrm{x}$ & & & & & & & & & & & & & & & & & & & & 6 & 22 \\
\hline 16 & $\mathrm{HC}$ & 2213-23-2 & Heptane, 2,4-dimethyl- & $\mathrm{x}$ & & & & & & & & $\mathrm{x}$ & & $\mathrm{x}$ & & $\mathrm{x}$ & $\mathrm{x}$ & $\mathrm{x}$ & & & & & & & & & & & & & 6 & 22 \\
\hline 17 & $\mathrm{HC}$ & $19549-87-2$ & 2,4-Dimethyl-1-heptene & $\mathrm{x}$ & $\mathrm{x}$ & & & & & & & $\mathrm{x}$ & & $\mathrm{x}$ & & $\mathrm{x}$ & $\mathrm{x}$ & & & & & & & & & & & & & & 6 & 22 \\
\hline 18 & $\mathrm{HC}$ & $112-31-2$ & Decanal & $x$ & & & & $\mathrm{x}$ & $x$ & $\mathrm{x}$ & $\mathrm{x}$ & & & & & & & & & & & & & & & & & & & $\mathrm{x}$ & 6 & 22 \\
\hline 19 & $\mathrm{HC}$ & $2847-72-5$ & Decane, 4-methyl- & & & & & & & & & & & & & $\mathrm{x}$ & $\mathrm{x}$ & $\mathrm{x}$ & $x$ & $\mathrm{x}$ & & & & & & & & & & & 5 & 19 \\
\hline 20 & $\mathrm{HC}$ & $2216-34-4$ & Octane, 4-methyl- & $x$ & $x$ & & & & & & & $\mathrm{x}$ & & $x$ & & $\mathrm{x}$ & & & & & & & & & & & & & & & 4 & 15 \\
\hline 21 & $\mathrm{HC}$ & $17302-27-1$ & Nonane, 2,5- dimethyl- & $\mathrm{x}$ & & & & & & & & & & $\mathrm{x}$ & & $\mathrm{x}$ & $\mathrm{x}$ & & & & & & & & & & & & & & 4 & 15 \\
\hline 22 & $\mathrm{HC}$ & $6117-97-1$ & Dodecane, 4-methyl- & & & & & & & & & $\mathrm{x}$ & & & & $\mathrm{x}$ & $\mathrm{x}$ & & $x$ & & & & & & & & & & & & 4 & 15 \\
\hline 23 & $\mathrm{HC}$ & $593-49-7$ & Heptacosane & & & & & & & & & $\mathrm{x}$ & & & & $\mathrm{x}$ & & & $\mathrm{x}$ & $\mathrm{x}$ & & & & & & & & & & & 4 & 15 \\
\hline 24 & $\mathrm{HC}$ & $5876-87-9$ & 1,11-Dodecadiene & $x$ & $\mathrm{x}$ & & & & & & & & & & & & & & & & & & & & & & & $x$ & & $\mathrm{x}$ & 4 & 15 \\
\hline 25 & $\mathrm{HC}$ & $589-43-5$ & Hexane, 2,4-dimethyl- & $\mathrm{x}$ & $\mathrm{x}$ & & & & & $x$ & & & & & & & & & & & & & & & & & & & & & 3 & 11 \\
\hline 26 & $\mathrm{HC}$ & $560-21-4$ & Pentane, 2,3,3-trimethyl- & & & & & $x$ & & $x$ & $\mathrm{x}$ & & & & & & & & & & & & & & & & & & & & 3 & 11 \\
\hline 27 & $\mathrm{HC}$ & $584-94-1$ & Hexane, 2,3-dimethyl- & & & & & $\mathrm{x}$ & $x$ & & $\mathrm{x}$ & & & & & & & & & & & & & & & & & & & & 3 & 11 \\
\hline 28 & $\mathrm{HC}$ & 589-53-7 & Heptane, 4-methyl- & $x$ & & & & & & & & & & $x$ & & $x$ & & & & & & & & & & & & & & & 3 & 11 \\
\hline 29 & $\mathrm{HC}$ & $66-25-1$ & Hexanal & & & & & $\mathrm{x}$ & & & & $\mathrm{x}$ & & & & & & & & & & & & & & & $x$ & & & & 3 & 11 \\
\hline 30 & $\mathrm{HC}$ & $871-83-0$ & Nonane, 2-methyl- & & & & & & & & & $x$ & & & & $\mathrm{x}$ & $\mathrm{x}$ & & & & & & & & & & & & & & 3 & 11 \\
\hline 31 & $\mathrm{HC}$ & 2051-30-1 & Octane, 2,6-dimethyl- & & & & & & & & & $x$ & & $\mathrm{x}$ & $\mathrm{x}$ & & & & & & & & & & & & & & & & 3 & 11 \\
\hline
\end{tabular}




\begin{tabular}{|c|c|c|c|c|c|c|c|c|c|c|c|c|c|c|c|c|c|c|c|c|c|c|c|c|c|c|c|c|c|c|c|c|}
\hline $\begin{array}{l}32 \\
33 \\
34 \\
\end{array}$ & $\begin{array}{l}\mathrm{HC} \\
\mathrm{HC} \\
\mathrm{HC} \\
\end{array}$ & $\begin{array}{l}7045-71-8 \\
17301-23-4 \\
629-62-9 \\
\end{array}$ & $\begin{array}{l}\text { Undecane, 2-methyl- } \\
\text { Dodecane, 4,6-dimethyl- } \\
\text { 1-Tridecene }\end{array}$ & & $x$ & & & & & & & $x$ & & & & $\begin{array}{l}x \\
x\end{array}$ & $\mathrm{x}$ & & $x$ & $\mathrm{x}$ & & & & & $x$ & & & & $\mathrm{x}$ & & $\begin{array}{l}3 \\
3 \\
3 \\
\end{array}$ & $\begin{array}{l}11 \\
11 \\
11 \\
\end{array}$ \\
\hline 35 & Benz & $24157-81-1$ & 2,6-Diisopropylnaphthalene & $x$ & $x$ & $\mathrm{x}$ & $x$ & $x$ & $\mathrm{x}$ & $\mathrm{x}$ & $\mathrm{x}$ & $x$ & $x$ & $x$ & $\mathrm{x}$ & $x$ & & & $x$ & $x$ & $x$ & $x$ & $x$ & $x$ & $x$ & $x$ & $x$ & $x$ & $x$ & & 24 & 89 \\
\hline 36 & Benz & $24157-81-1$ & 2,6-Diisopropylnaphthalene & $x$ & $x$ & $x$ & & $x$ & $x$ & $x$ & $x$ & $x$ & & $x$ & $x$ & $x$ & & & $x$ & $x$ & $x$ & $x$ & $x$ & $x$ & $x$ & $x$ & $x$ & $x$ & $x$ & $x$ & 23 & 85 \\
\hline 37 & Benz & $108-88-3$ & Toluene & & & $\mathrm{x}$ & $\mathrm{x}$ & $\mathrm{x}$ & $\mathrm{x}$ & $\mathrm{x}$ & $\mathrm{x}$ & & & $\mathrm{x}$ & $\mathrm{x}$ & $x$ & $\mathrm{x}$ & $x$ & $\mathrm{x}$ & $x$ & & & $\mathrm{x}$ & & $x$ & $\mathrm{x}$ & $\mathrm{x}$ & $x$ & $\mathrm{x}$ & $\mathrm{x}$ & 20 & 74 \\
\hline 38 & Benz & $24157-81-1$ & 2,6-Diisopropylnaphthalene & $x$ & & $x$ & & $x$ & $\mathrm{x}$ & $x$ & $x$ & $x$ & & $x$ & $x$ & $x$ & & & & $x$ & $x$ & $x$ & $x$ & $x$ & $x$ & $x$ & $x$ & $x$ & $x$ & & 20 & 74 \\
\hline 39 & Benz & $106-42-3$ & p-Xylene & & & $x$ & $x$ & $x$ & $\mathrm{x}$ & $x$ & $\mathrm{x}$ & & & $x$ & $x$ & & $\mathrm{x}$ & & $x$ & & & & & & & $x$ & $x$ & $x$ & & & 13 & 48 \\
\hline 40 & Benz & $100-41-4$ & $\begin{array}{l}\text { Ethylbenzene } \\
\text { Benzene, } 1 \text {-(1,5-dimethyl-4-hexenyl)-4- }\end{array}$ & & & $\mathrm{x}$ & $\mathrm{x}$ & $x$ & $\mathrm{x}$ & $\mathrm{x}$ & $\mathrm{x}$ & & $\mathrm{x}$ & & $\mathrm{x}$ & & & & & & & & & & & $\mathrm{x}$ & $x$ & $\mathrm{x}$ & & & 11 & 41 \\
\hline 41 & Benz & $644-30-4$ & methyl & & & & & $x$ & $\mathrm{x}$ & $x$ & $x$ & $x$ & $x$ & & & & $x$ & & & & & & & & $x$ & & $x$ & & & & 9 & 33 \\
\hline 42 & Benz & $24157-81-1$ & 2,6-Diisopropylnaphthalene & & & $\mathrm{x}$ & & & & & & $x$ & $x$ & $x$ & & & $x$ & & & & & & & & $x$ & $x$ & $\mathrm{x}$ & & $x$ & & 9 & 33 \\
\hline 43 & Benz & $526-73-8$ & Benzene, 1,2,3,-trimethyl- & $\mathrm{x}$ & & $x$ & & $x$ & $\mathrm{x}$ & $x$ & $x$ & & & & & & $x$ & & & & & & & & & & & & & & 8 & 30 \\
\hline 44 & Benz & $4621-36-7$ & Benzene, (1-ethyloctyl) & & & $x$ & $x$ & & & $\mathrm{x}$ & $x$ & & & $\mathrm{x}$ & & & & $\mathrm{x}$ & $\mathrm{x}$ & $\mathrm{x}$ & & & & & & & & & & & 8 & 30 \\
\hline 45 & Benz & $95-47-6$ & o-Xylene & & & & & $x$ & $\mathrm{x}$ & $x$ & & & & & & & & & & & & & & & & $x$ & $x$ & $x$ & & $x$ & 7 & 26 \\
\hline 46 & Benz & $108-67-8$ & Benzene, 1,3,5-trimethyl- & & & $x$ & $x$ & $x$ & $x$ & $x$ & $x$ & & & $x$ & & & & & & & & & & & & & & & & & 7 & 26 \\
\hline 47 & Benz & $24157-81-1$ & 2,6-Diisopropylnaphthalene & $\mathrm{x}$ & $\mathrm{x}$ & $\mathrm{x}$ & & $\mathrm{x}$ & $\mathrm{x}$ & $\mathrm{x}$ & $\mathrm{x}$ & & & & & & & & & & & & & & & & & & & & 7 & 26 \\
\hline 48 & Benz & 611-14-3 & Benzene, 1-ethyl-2-methyl- & & & $x$ & $x$ & $x$ & $x$ & $x$ & $x$ & & & & & & & & & & & & & & & & & & & & 6 & 22 \\
\hline 49 & Benz & $71-43-2$ & Benzene & $\mathrm{x}$ & $\mathrm{x}$ & $\mathrm{x}$ & $x$ & & $\mathrm{x}$ & $\mathrm{x}$ & & & & & & & & & & & & & & & & & & & & & 6 & 22 \\
\hline 50 & Benz & $4537-15-9$ & Benzene, (1-butylheptyl)- & & & $x$ & $x$ & & $x$ & $x$ & $x$ & & & & & & & & & & & & & & & & & & & & 5 & 19 \\
\hline 51 & Benz & $4536-86-1$ & Benzene, (1-propyloctyl)- & & & $x$ & $x$ & & $\mathrm{x}$ & $x$ & $x$ & & & & & & & & & & & & & & & & & & & & 5 & 19 \\
\hline 52 & Benz & & Benzene methanol, $\alpha$ - $\alpha$-dimethyl- & $x$ & $x$ & & & & $\mathrm{x}$ & $\mathrm{x}$ & $\mathrm{x}$ & & & & & & & & & & & & & & & & & & & & 5 & 19 \\
\hline 53 & Benz & $620-14-4$ & Benzene, 1-ethyl-3-methyl- & & & $x$ & $x$ & $x$ & $\mathrm{x}$ & & & & & & & & & & & & & & & & & & & & & & 4 & 15 \\
\hline 54 & Benz & $535-77-3$ & Benzene, 1-methyl-3-(1-methylethyl) & & & & & $x$ & & $x$ & $x$ & & & & & & & & & & & & & & & & & $x$ & & & 4 & 15 \\
\hline 55 & Benz & $4537-11-5$ & Benzene, (1-butylhexyl)- & & & & $x$ & & $\mathrm{x}$ & $x$ & & & & & & & & & & & & & & & & & & & & & 3 & 11 \\
\hline 56 & Benz & $4537-12-6$ & Benzene, (1-propylheptyl)- & & & & $x$ & & $\mathrm{x}$ & $\mathrm{x}$ & & & & & & & & & & & & & & & & & & & & & 3 & 11 \\
\hline 57 & MT & $79-92-5$ & Camphene & $x$ & $x$ & $\mathrm{x}$ & $x$ & $x$ & $\mathrm{x}$ & $\mathrm{x}$ & $x$ & $x$ & $x$ & & & $x$ & $x$ & $x$ & $x$ & $x$ & $x$ & $x$ & $x$ & $x$ & $x$ & $x$ & $x$ & $x$ & $x$ & & 24 & 89 \\
\hline 58 & MT & $13877-91-3$ & $\beta$-Ocimene $(6 \mathrm{Cl})$ & $x$ & & $x$ & $x$ & $x$ & $\mathrm{x}$ & $x$ & $\mathrm{x}$ & $x$ & $\mathrm{x}$ & $\mathrm{x}$ & $\mathrm{x}$ & $x$ & & $x$ & $\mathrm{x}$ & $x$ & $x$ & $x$ & $x$ & $x$ & $x$ & 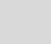 & & & $x$ & & 21 & 78 \\
\hline 59 & MT & $7785-70-8$ & 1R-a-Pinene & $x$ & $\mathrm{x}$ & $\mathrm{x}$ & $x$ & $x$ & $\mathrm{x}$ & $\mathrm{x}$ & $\mathrm{x}$ & & & 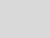 & & $x$ & $x$ & & & & & & & & & $\mathrm{x}$ & $\mathrm{x}$ & $\mathrm{x}$ & $\mathrm{x}$ & $\mathrm{x}$ & 15 & 56 \\
\hline 60 & MT & $13466-78-9$ & 3-Carene & & & $x$ & & $x$ & $\mathrm{x}$ & $x$ & $\mathrm{x}$ & & & $x$ & & $x$ & & & & & & & $x$ & & $x$ & $x$ & $x$ & $x$ & $x$ & $x$ & 14 & 52 \\
\hline 61 & MT & $18172-67-3$ & (-)-B-Pinene & $\mathrm{x}$ & $\mathrm{x}$ & $\mathrm{x}$ & & $x$ & $\mathrm{x}$ & $\mathrm{x}$ & $\mathrm{x}$ & & & & & $x$ & & $\mathrm{x}$ & $x$ & $x$ & & & & & & & & & & & 11 & 41 \\
\hline 62 & MT & $138-86-3$ & $\begin{array}{l}\text { Limonene } \\
\text { (+)-B-Pinene }\end{array}$ & & & & & & $\mathrm{x}$ & $x$ & $\mathrm{x}$ & & & & & & & & $x$ & $x$ & & & & & & $x$ & $\mathrm{x}$ & & $x$ & & 8 & 30 \\
\hline 63 & MT & & (+)-B-Pinene & & & & & & & & & & & & & & & & & & & & & & & $\mathrm{x}$ & $\mathrm{x}$ & $\mathrm{x}$ & $\mathrm{x}$ & $\mathrm{x}$ & 5 & 19 \\
\hline 64 & MT & & (+)-3-Carene & $x$ & $x$ & & $x$ & & & & & & & & & & & & & & & & & & & & & & & & 3 & 11 \\
\hline 65 & ST & $5989-08-2$ & $(+)$ - $\alpha$-Longipinene & $x$ & $x$ & $x$ & $x$ & $x$ & $\mathrm{x}$ & $x$ & $\mathrm{x}$ & $x$ & $x$ & $x$ & $x$ & $x$ & $x$ & $x$ & $x$ & $x$ & $x$ & $x$ & $x$ & $\mathrm{x}$ & $x$ & $x$ & $x$ & $x$ & $x$ & $x$ & 27 & 100 \\
\hline 66 & ST & $22469-52-9$ & (+)-Cyclosativene & $\mathrm{x}$ & $\mathrm{x}$ & $\mathrm{x}$ & $\mathrm{x}$ & $x$ & $\mathrm{x}$ & $x$ & $\mathrm{x}$ & $x$ & $\mathrm{x}$ & $\mathrm{x}$ & $\mathrm{x}$ & $x$ & $\mathrm{x}$ & $x$ & $\mathrm{x}$ & $x$ & $x$ & $x$ & $x$ & $\mathrm{x}$ & $x$ & $\mathrm{x}$ & $\mathrm{x}$ & $\mathrm{x}$ & $\mathrm{x}$ & & 26 & 96 \\
\hline 67 & ST & $17699-14-8$ & a-Cubene & $\mathrm{x}$ & $x$ & $\mathrm{x}$ & $x$ & $x$ & $\mathrm{x}$ & $\mathrm{x}$ & $x$ & $x$ & $\mathrm{x}$ & $\mathrm{x}$ & $\mathrm{x}$ & $x$ & $\mathrm{x}$ & $x$ & $x$ & $\mathrm{x}$ & $x$ & $\mathrm{x}$ & $x$ & $x$ & $x$ & $\mathrm{x}$ & $\mathrm{x}$ & $\mathrm{x}$ & $\mathrm{x}$ & & 26 & 96 \\
\hline 68 & ST & $475-20-7$ & (+)-Longifolene & $\mathrm{x}$ & $\mathrm{x}$ & $\mathrm{x}$ & & $x$ & $\mathrm{x}$ & $\mathrm{x}$ & & $x$ & $x$ & $x$ & $x$ & $x$ & $x$ & $x$ & $x$ & $x$ & $x$ & $\mathrm{x}$ & $x$ & $x$ & $x$ & $\mathrm{x}$ & $x$ & & $\mathrm{x}$ & & 23 & 85 \\
\hline
\end{tabular}




\begin{tabular}{|c|c|c|c|c|c|c|c|c|c|c|c|c|c|c|c|c|c|c|c|c|c|c|c|c|c|c|c|c|c|c|c|c|}
\hline $\begin{array}{l}69 \\
70\end{array}$ & $\begin{array}{l}\text { ST } \\
\text { ST }\end{array}$ & $87-44-5$ & $\begin{array}{l}\text { Caryophyllene } \\
\delta \text {-Curcumene }\end{array}$ & $\begin{array}{l}x \\
x\end{array}$ & $x$ & $x$ & $\begin{array}{l}x \\
x\end{array}$ & $\begin{array}{l}x \\
x\end{array}$ & $\mathrm{x}$ & $\begin{array}{l}x \\
x\end{array}$ & $\mathrm{x}$ & $\begin{array}{l}x \\
x\end{array}$ & $\begin{array}{l}\mathrm{x} \\
\mathrm{x}\end{array}$ & $\begin{array}{l}x \\
x\end{array}$ & $\begin{array}{l}x \\
x\end{array}$ & $x$ & $\begin{array}{l}\mathrm{x} \\
\mathrm{x}\end{array}$ & $x$ & $\begin{array}{l}x \\
x\end{array}$ & $\mathrm{x}$ & $x$ & $x$ & $\begin{array}{l}x \\
x\end{array}$ & $\begin{array}{l}x \\
x\end{array}$ & $\begin{array}{l}x \\
x\end{array}$ & & $x$ & & $\begin{array}{l}x \\
x\end{array}$ & $x$ & $\begin{array}{l}23 \\
16\end{array}$ & $\begin{array}{l}85 \\
59\end{array}$ \\
\hline 71 & ST & $17928-54-0$ & B-Himachalene & $x$ & $x$ & $x$ & & $x$ & $x$ & $x$ & $\mathrm{x}$ & $x$ & $x$ & $x$ & $x$ & & & & & & & & & $x$ & $x$ & & & & & & 13 & 48 \\
\hline 72 & ST & & a-Himachalene & & $\mathrm{x}$ & & & & & & & $x$ & $\mathrm{x}$ & $\mathrm{x}$ & $\mathrm{x}$ & & & $\mathrm{x}$ & & $x$ & $x$ & $\mathrm{x}$ & $\mathrm{x}$ & & $x$ & & $\mathrm{x}$ & & & & 12 & 44 \\
\hline 73 & ST & $489-40-7$ & a-Gurjunene & $\mathrm{x}$ & $\mathrm{x}$ & & & $x$ & $\mathrm{x}$ & $\mathrm{x}$ & & $x$ & $\mathrm{x}$ & & & & & & & & & & $x$ & $x$ & $x$ & & & & & & 10 & 37 \\
\hline 74 & ST & $483-76-1$ & $\delta$-Cardinene & & & $\mathrm{x}$ & & $\mathrm{x}$ & $\mathrm{x}$ & $\mathrm{x}$ & $\mathrm{x}$ & $x$ & $\mathrm{x}$ & & & & & & & & & & & $\mathrm{x}$ & $x$ & & & $\mathrm{x}$ & & & 10 & 37 \\
\hline 75 & ST & & (-)-Isoledene & & & & & $x$ & $\mathrm{x}$ & $\mathrm{x}$ & $\mathrm{x}$ & $x$ & $\mathrm{x}$ & & & & & & & & & & $x$ & $x$ & $x$ & & & & & & 9 & 33 \\
\hline 76 & ST & & trans- $\alpha$-Bergamotene & & & & & & & & & & & & & & & & & & & & $x$ & $x$ & $x$ & $x$ & $x$ & $\mathrm{x}$ & & $x$ & 7 & 26 \\
\hline 77 & ST & & (-)-Sesquiphellandrene & & & & & & $\mathrm{x}$ & & & $x$ & & & & & & & & & & & $\mathrm{x}$ & $\mathrm{x}$ & $x$ & & & & & & 5 & 19 \\
\hline 78 & ST & & $\alpha$-Caryophyllene & & & & $x$ & & $x$ & $x$ & $\mathrm{x}$ & & & & & & & $x$ & & & & & & & & & & & & & 5 & 19 \\
\hline 79 & ST & & (+)-Aromadendrene & & & $x$ & & $x$ & $x$ & & & $x$ & $x$ & & & & & & & & & & & & & & & & & & 5 & 19 \\
\hline 80 & ST & $495-60-3$ & Zingiberene & & & & $\mathrm{x}$ & $x$ & $\mathrm{x}$ & $\mathrm{x}$ & $\mathrm{x}$ & & & & & & & & & & & & & & & & & & & & 5 & 19 \\
\hline
\end{tabular}




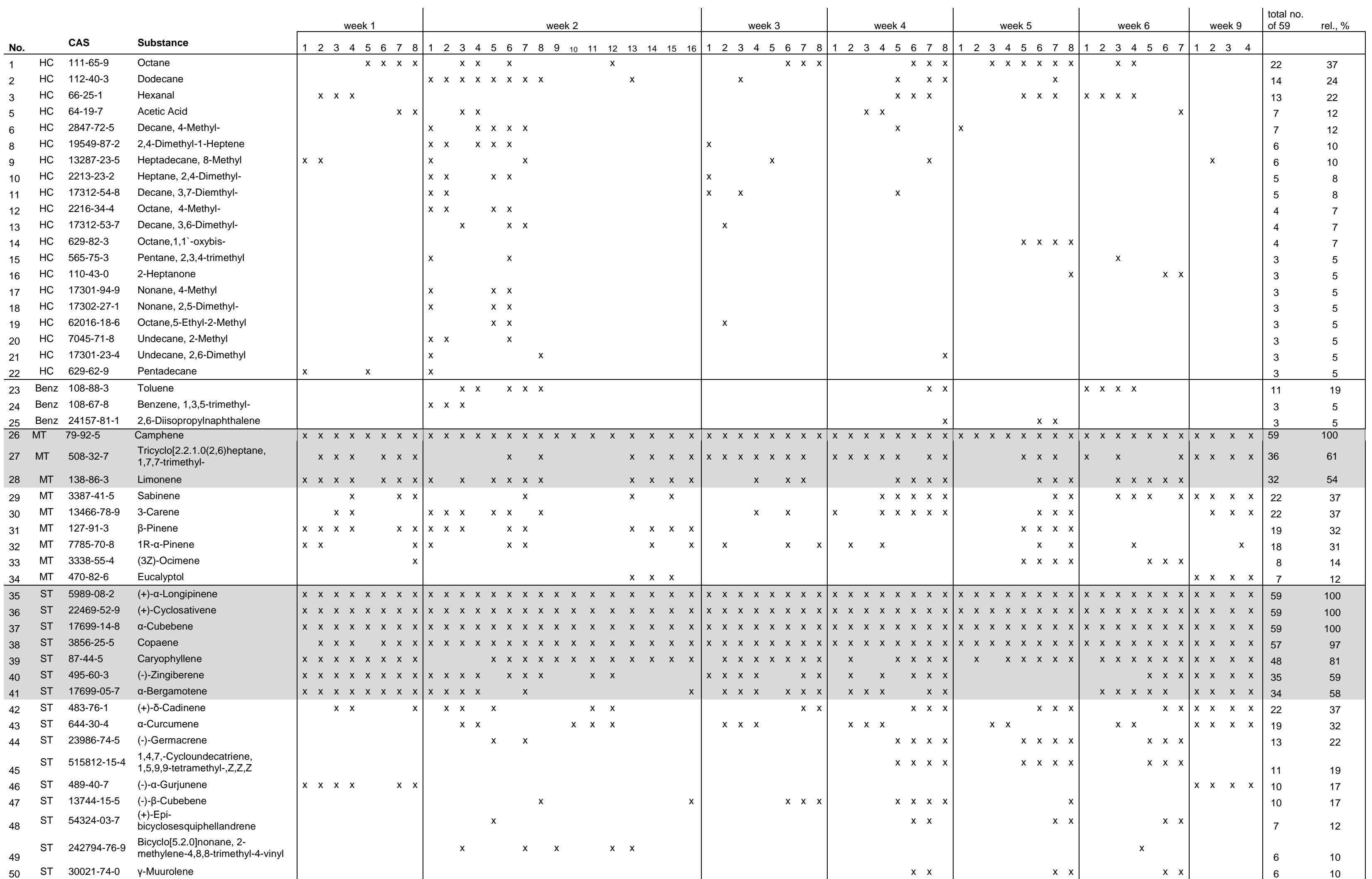




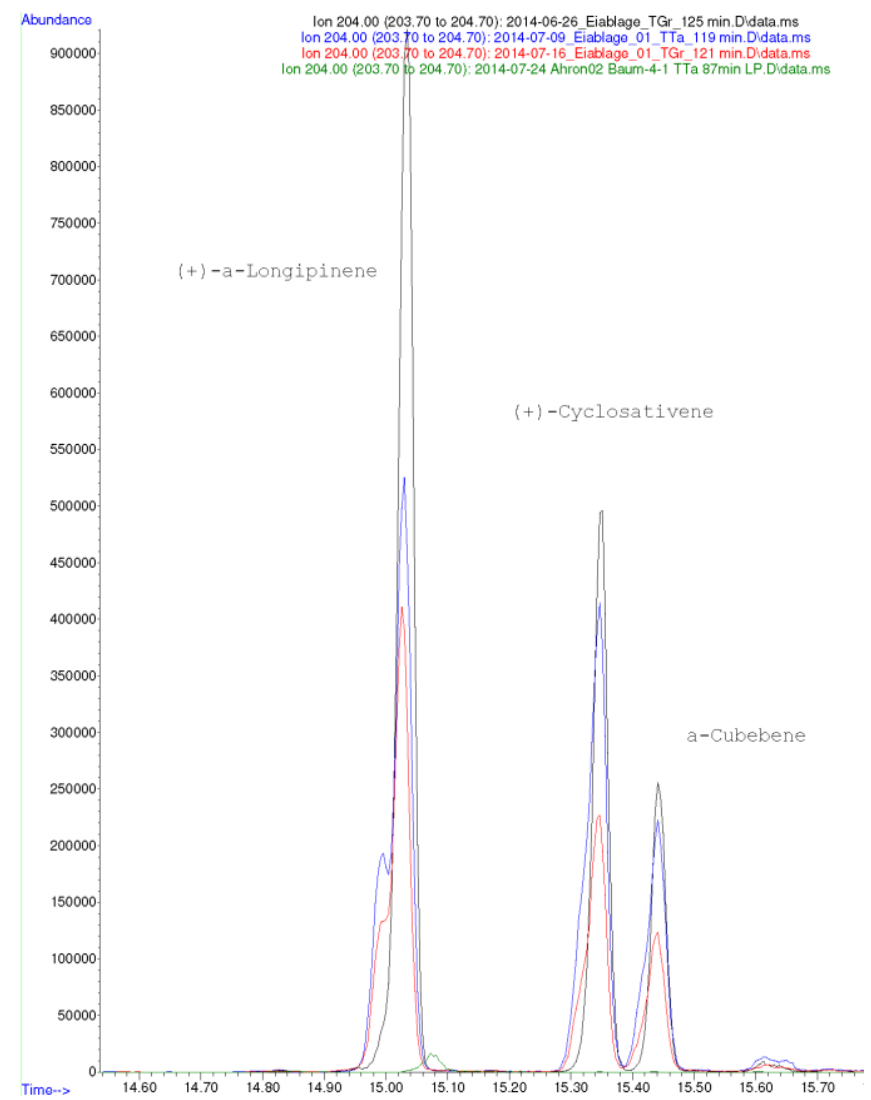

Figure 6: Overlay of chromatograms: in black, blue and red trunk with ALB oviposition on Acer, in green healthy trunk of Acer 


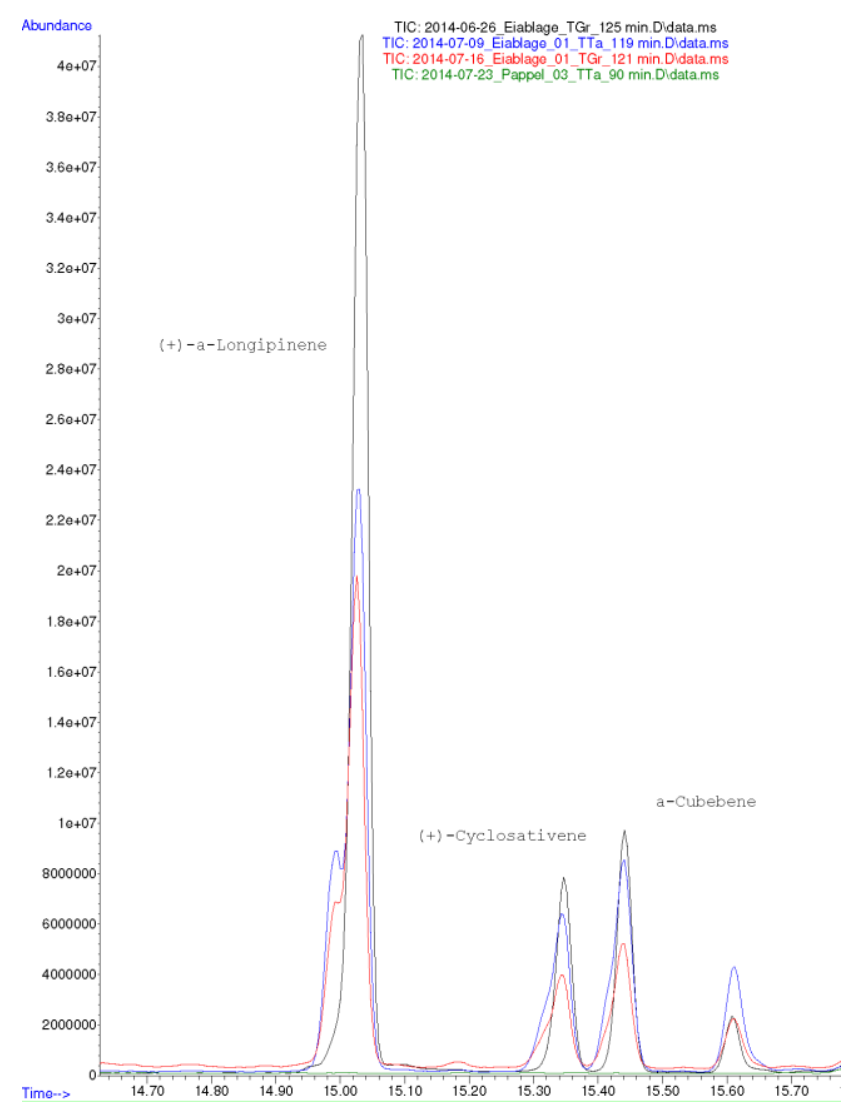

Figure 7: Overlay of chromatograms: in black, blue and red trunk with ALB oviposition on Acer, in green healthy trunk of Populus 


\title{
3 Part II: Identification of Anoplophora glabripennis (Moschulsky) by its emitted specific volatile organic compounds
}

\author{
Makarow, Ramona'; Schäfer, Sara'; Kaul, Peter ${ }^{1}$ \\ 'Safety and Security Research Institute, Institute of Detection Technologies, Hochschule Bonn-Rhein-Sieg \\ University of Applied Sciences, von-Liebig-Straße 20, 53359 Rheinbach, Germany
}

This chapter is published in 'Scientific Reports': Scientific Reports 10, 5194 (2020). https://doi.org/10.1038/s41598-020-61897-0

\subsection{ABSTRACT}

Explorative experiments were done to figure out differences in the emission of volatile organic compounds (VOCs) of not infested trees and trees infested by Anoplophora glabripennis (Asian longhorn beetle, ALB), a quarantine pest. Therefore, VOCs from some native insect species, Anoplophora glabripennis infested Acer, stressed Acer, healthy Acer, Populus and Salix were obtained by enrichment on adsorbents. Qualitative analysis was done by thermal desorption gas chromatography coupled with a mass selective detector (TD-GC/MS).

Altogether 169 substances were identified. 11 substances occur from ALB infested or mechanically damaged trees i.e. stressed trees, but not from healthy trees. (+)-Cyclosativene, (+)- $\alpha$-longipinene, copaene and caryophyllene are detectable only from ALB-infested Acer not from mechanically damaged or healthy Acer. However, these substances are also emitted by healthy Salix.

2,4-Dimethyl-1-heptene is among all tree samples exclusively present in the ambience of ALB-infested trees. It is rarely detectable from native insect species' samples.

Keywords:

Anoplophora glabripennis, specific volatile organic compounds, TD-GC/MS, quarantine pest 


\subsection{INTRODUCTION}

During the last years the threat through invasive species has increased (Acosta et al. 2016). The main reasons for a further increase of invasive species in the next years are international trade due to globalisation and climatic changes (Acosta et al. 2016). Increasing temperatures show an influence on the duration of lifecycle and development of insects. With regards to infested areas in Italy, Bidinger et al. expects a shift of infested areas northwards and therefore an extension of infested areas (Bidinger 2012). Concerning Anoplophora glabripennis (ALB), an increase in damage is expected due to its high ability of adaption (Bidinger 2012). Currently, invasive insects' damage is estimated at US $\$ 70.0$ billion per year globally and US\$3.6 billion per year in Europe. One of the costliest insects is Anoplophora glabripennis with an estimated damage of US $\$ 3.0$ billion per year in North America and Europe (Bradshaw et al. 2016).

Counter measures are visual monitoring of infested areas, pheromone traps and, to some extent, sniffer dogs (Trotter und Keena 2016; Xu et al. 2017). Sniffer dogs seem to be a good choice especially for major area infestations or major quarantine zones. Besides the use of sniffer dogs for the detection of explosives and for Mantrailing (Marchal et al. 2016), in the last years, sniffer dogs have been used for new purposes. They are used for health reasons like the detection of cancer (Boedeker et al. 2012; Elliker et al. 2014; Guerrero-Flores et al. 2017; Hackner et al. 2016; Panebianco et al. 2018; Schallschmidt et al. 2016; Seo et al. 2018) as well as for the search for corpses (human remains detection) (DeGreeff und Furton 2011), bacteria in milk (Fischer-Tenhagen et al. 2018) or wildlife detection (Mills 2018). DeGreef et al. (DeGreeff und Furton 2011) were able to show distinct differences concerning the VOC odour profiles of deceased bodies, living human objects and animal remains. The identification of VOCs plays an important role for the identification of cancer markers in patients' breath or liquids (Schallschmidt et al. 2016; Willis et al. 2010). Though the use of sniffer dogs still offers a variety of advantages in the detection of odourants (Furton et al. 2015), VOCs have become more relevant as instrumental analytical methods, as well as their detection limits, are constantly improved. Influence parameters on the success of a canine's search are unclear and not completely investigated, however, there is consensus that a copious knowledge of the target's scent is essential. Thus, more effort has been put into the investigation of volatile organic compounds (VOCs) of the sniffer dog's target substance, considering a difference in odour between the different sources and an aging process for chemical and biological targets. The knowledge and use of target specific odorous substances can lead to significant improvement in sniffer dog's training and, as a result, discriminating capacity. The knowledge of target substances is also required for the development of technical detectors based on sensory systems.

Concerning ALB, Makarow et al. were able to identify the VOCs emitted by different types of ALB samples (imagoes, larvae and ovipositions) (Makarow et al. 2019).

The distinction to native insect species and not infested trees were not yet investigated. The analysis of these samples is necessary to figure out specific substances among the 229 identified VOCs. With this work we fill the gap and focus on the determination of the specific ALB volatiles emitted by the quarantine pest ALB. Part of this scope was the development of an approach to extract the specific VOCs, which enable the identification of an ALB infestation in air. 


\subsection{Materials and Methods}

The sampling procedure on adsorption tube from headspace vials and from tree trunks and the analytical methods were carried out in the way Makarow et al. (Makarow et al. 2019) described them. The same instrument was used. However, the main analysis parameters and procedures are mentioned in this section for the sake of completeness.

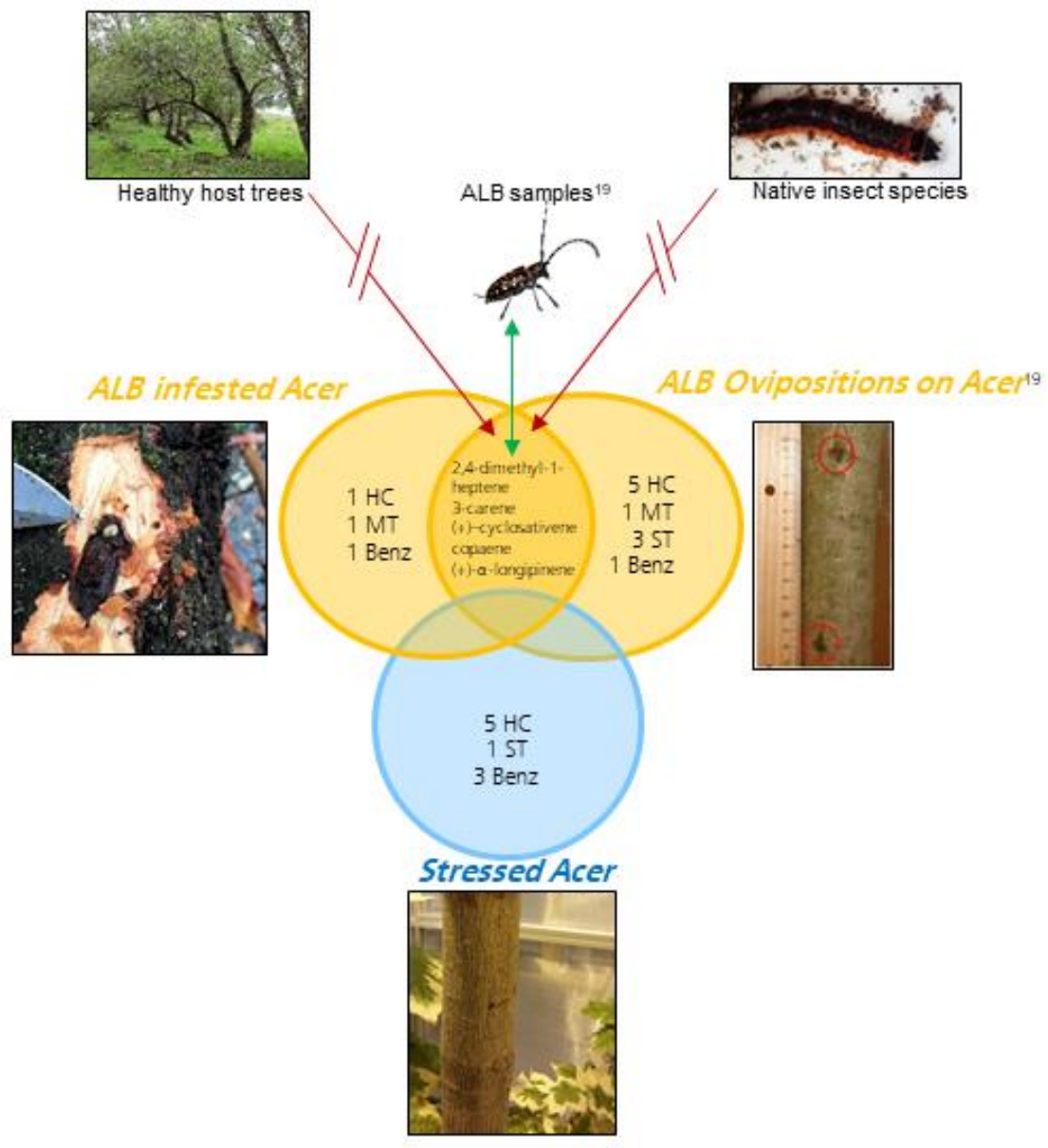

Figure 8: scheme of extracting the specific volatile organic compounds emitted from Anoplophora glabripennis including the analysis carried out by Makarow et al.(Makarow et al. 2019). The green arrow indicates the overlap of substances to the substances detected from standalone ALB samples. The red arrows indicate that no overlap of substances of healthy trees as well as of native insect species is requested.

\subsubsection{Samples}

An overview of analysed samples and the used sampling procedure is offered in Table 11. ALB infested trees were measured in five series of measurements, of which two generations of infested trees were analysed (Acer I/ Acer II, see Table 13). Acer I-III were measured in a row with one- to two-month delay between the series. Acer II-I and II-II were also measured in a row with a delay of two weeks. The infested trees were located in the quarantine facilities of the plant protection service of Northrhine-Westfalia (PPS NRW) and cultivated under constant greenhouse conditions. 
Trees of the type Acer without ALB infestation but with mechanical damage (cutting of the branches) and stress (insufficient light and water supply, 'non-ALB stressed trees') were measured in three series, they were also located in the facilities of the PPS NRW and cultivated under constant greenhouse conditions.

ALB infested Acer and non-ALB stressed Acer were cultivated indoors with artificial light supply and constant temperatures between 20 and $25^{\circ} \mathrm{C}$ and a photoperiod of $12 \mathrm{~h} / 12 \mathrm{~h}$ light/dark.

Table 11: Overview of the analysed samples, the environment of analysis and the sampling procedure including enrichment parameters.

\begin{tabular}{llllcc} 
Sample & Sample type & Environment & sampling method & $\begin{array}{c}\text { enrichment } \\
\text { duration, min }\end{array}$ & $\begin{array}{c}\text { Flowrate, } \\
\text { ml/min }\end{array}$ \\
\hline $\begin{array}{l}\text { ALB infested Acer } \\
\text { Stressed Acer }\end{array}$ & tree & Greenhouse & on the trunk & 90 & 30 \\
$\begin{array}{l}\text { Zeuzera pyrina infested } \\
\text { Populus }\end{array}$ & tree & Greenhouse & on the trunk & 90 & 30 \\
Saperda cacharias & pupa & laboratory & Headspace-Vial & 90 & 30 \\
& frass & laboratory & Headspace-Vial & 90 & 30 \\
Cossus cossus & larva & laboratory & Headspace-Vial & 90 & 30 \\
Aromia moschata & imago & laboratory & Headspace-Vial & 90 & 30 \\
& larva & laboratory & Headspace-Vial & 90 & 30 \\
Salix (healthy) & tree & open-land & on the trunk & 90 & 30 \\
$\begin{array}{l}\text { Populus (healthy) } \\
\text { Acer (healthy) }\end{array}$ & tree & open-land & on the trunk & 90 & 30
\end{tabular}

Native insect species samples were Zeuzera pyrina infested Populus on open land (sampling method was via the foil wrapped trunk described in 3.3.2, see Figure 9), Saperda cacharias pupa, Aromia moschata imago and larva and frass from Cossus cossus larva (sampling method see Figure 10).

As a reference, healthy trees of the types Populus, Acer and Salix were analysed in open field. Open land measurements were carried out as open land offers the best circumstances for healthy trees. The three types are the most common host trees of ALB in Europe (JKI, 2016). The sampling method is described in 3.3.2 (see also Figure 9).

\subsubsection{Sampling procedures}

Alive beetles and larvae and frass were put into a $20 \mathrm{ml}$ headspace glass vial for the duration of the enrichment of the VOCs on adsorbents. Two small cuts in the septum were used for the enrichment, whereas the pump was adjusted at one hole so that the ambient air was carried over the sample onto the adsorbents tube (see Figure 10). 


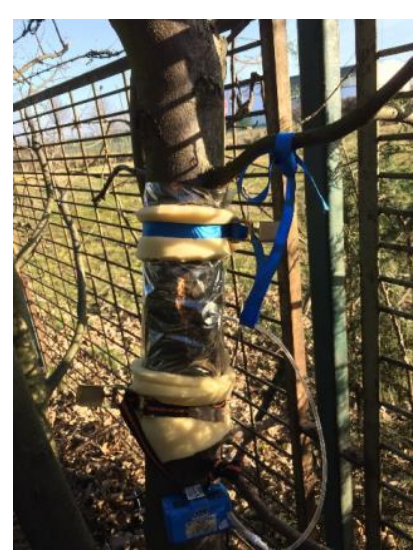

Figure 9: sampling procedure on a tree trunk. The analysed part is wrapped in Nalophan foil, closed with staples and tension belts.

The healthy, the ALB infested trees and the non-ALB stressed trees were analysed directly on the trunk (see Figure 9). Therefore, the sampling method described by Makarow et al. was used as the same sampling method was applied (Makarow et al. 2019). Makarow et al. use Nalophan foil for wrapping and staples and tension belts for closing the foil. A self-built adapter is used to adapt the adsorbents tube on the foil. A pump is used to lead the VOCs from the trunk to the adsorbents tube.

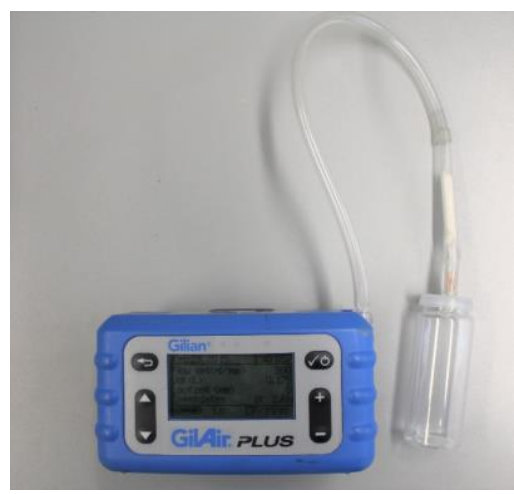

Figure 10: Sampling procedure for beetles, pupae and frass. The samples are stored in the headspace vial while sampling with the pump

For all samples the enrichment time was 90 minutes; flow rate was $30 \mathrm{ml} / \mathrm{min}$. Pumps of two different types were used, namely Gilian GilAir Plus and Gilian LFP-113DC Low Flow Sampler. The flow for the Gilian LFP was adjusted by the Analyt-MTC mass-flow-meter (Analyt-MTC Messtechnik GmbH, Germany). After the enrichment, the adsorbent tubes were immediately stored at $-18{ }^{\circ} \mathrm{C}$ in a mobile freezer for a maximum of $24 \mathrm{~h}$. Afterwards, the tubes were analysed by TD-GC/MS (Makarow et al. 2019).

\subsubsection{Conditioning of adsorption tubes}

Glass tubes $(6.0 \mathrm{~cm} \times 0.5 \mathrm{~cm})$ were filled with $120 \mathrm{mg}$ of the adsorbents Tenax® TA or Tenax® GR fixed in place by glass wool. Freshly-filled adsorbent tubes were conditioned once by five-times elution with an acetone/water (90/10) solution, drying at $50{ }^{\circ} \mathrm{C}$ for $24 \mathrm{~h}$ and placing them three times into an oven at $280^{\circ} \mathrm{C}$, each $1 \mathrm{~h}$, while carbon filtered $\mathrm{N}_{2}$ (5.0) with a constant flow was transferred through the tubes. For 
reconditioning, tubes were placed into an oven at $280^{\circ} \mathrm{C}$ for $1 \mathrm{~h}$ while carbon filtered $\mathrm{N}_{2}$ of constant flow was carried through the tubes. The efficiency of the procedure was controlled by blank analysis. The method was first described by Makarow et al. (Makarow et al. 2019).

Enrichment duration of the volatiles was 90 minutes and enrichment flow was $30 \mathrm{ml} / \mathrm{min}$. Tenax TA and Tenax GR were used for the enrichment of volatiles for the measurements in this paper.

\subsubsection{Instruments}

The chromatographic analysis was performed using a 7890A/5975C inert XN MSD GC/MS device (Agilent Technologies) coupled to a thermal desorption unit from Gerstel. The GC was equipped with a DB5-MS capillary column from J\&W (30 m x $0.250 \mathrm{~mm} ; 0.25 \mu \mathrm{m})$. Helium 5.0 was used as a carrier gas and the inlet pressure was 9.1473 psi, which corresponds to a flow of $1.2 \mathrm{ml} / \mathrm{min}$.

\section{Chromatographic analysis}

According to Makarow et al. the Cooled Injection System (CIS) was cooled to $-120^{\circ} \mathrm{C}$ then heated to $250{ }^{\circ} \mathrm{C}$ at $12{ }^{\circ} \mathrm{C} / \mathrm{min}$ and held for 3 minutes. The thermodesorption unit had an initial temperature of $30^{\circ} \mathrm{C}$ and was heated to $230^{\circ} \mathrm{C}$ at $40^{\circ} \mathrm{C} / \mathrm{min}$ and held for 1 minute. The transfer temperature was $240{ }^{\circ} \mathrm{C}$. The desorption mode was splitless (Makarow et al. 2019).

The $\mathrm{GC}$ temperature program was held for 2 minutes at $35^{\circ} \mathrm{C}$, then increased to $170^{\circ} \mathrm{C}$ at $8{ }^{\circ} \mathrm{C} / \mathrm{min}$, then to $240^{\circ} \mathrm{C}$ at $60^{\circ} \mathrm{C} / \mathrm{min}$ and finally held for 2 minutes. Altogether the analysis was carried out with a 1:15 split. Liner temperature was kept to $250^{\circ} \mathrm{C}$ (Makarow et al. 2019).

The complete desorption of VOCs from the adsorbents by the described method was tested by the double analysis of some samples. The double analysis was performed in five time repetitions as part of the development of the analytical method and randomly during the sample analysis stage. The second analysis led to the same results as blanks. Thus it can be expected that the method leads to a total desorption of the analytes from the adsorbents.

The mass spectra were recorded in the electron-impact mode $(70 \mathrm{eV})$ from 30 to $400 \mathrm{DA}$. Each peak in the chromatogram was identified by comparing the fragmentation pattern typical of each compound to the National Institute of Standards and Technology (NIST) 5.0 database. Only substances with a minimum of $80 \%$ match and reproducible retention times in at least three measurements were considered as unambiguous substance identification (Makarow et al. 2019). The substances 2,4-dmethyl-1-heptene, (+)- $\alpha$-longipinene, (+)-cyclosativene and (-)-trans-caryophyllene were qualified by standards.

\subsubsection{Chemicals and adsorbent material}

For the conditioning of the adsorbents tubes, acetone of HPLC grade (Rotisolve, Carl Roth GmbH + Co KG, (Germany)) was used. The water was self-purified by a MilliQ System. For the enrichment Tenax TA (mesh 60/80) and Tenax GR (mesh 20/35) (Alltech Associates Inc.; Buchem BV (Netherlands)) and silanized glass wool (Sigma Aldrich (Germany)) were used. For tubing Tygon tubes (Carl Roth GmbH + Co KG (Germany)) were used. The Nalophan foil from Kalle GmbH (Germany) was used for wrapping. 
As standards 2,4-dimethyl-1-heptene (CAS 19549-87-2, 95 \%) from Combi-Blocks, (+)- $\alpha$-longipinene (CAS 5989-08-2, $\geq 99 \%$ sum of enantiomers) from Aldrich, (+)-cyclosativene (CAS 22469-52-9, 99 \%) from Sigma-Aldrich and (-)-trans-caryophyllene from Sigma-Aldrich (all purchased from Merck (Germany)) were used. The standards were dissolved in methanol (Rotisolve $\geq 99.98 \%$; Carl Roth GmbH + Co KG (Germany)). A volume of $50 \mu \mathrm{l}$, which corresponds a mass of $100 \mathrm{ng}$ of each standard, were injected on the adsorbents with a microliter syringe (Hamilton). The solvent was dried by pumping ambient air with a flow of $400 \mathrm{ml} / \mathrm{min}$ for 4 minutes over the adsorbents tube. In order to exclude contaminations, the drying procedure was carried out with blank adsorbents.

\subsection{RESULTS}

With the scope of determining the specific volatile of Anoplophora glabripennis the following analysis were carried out: when considering the stress induced change of VOC pattern of a plant, the first step was the analysis of ALB infested Acer (with larvae inside and with fresh ovipositions) and non-ALB stressed Acer. The VOCs deriving from the two types of ALB infested Acer, but not detectable from non-ALB stressed Acer were considered ALB induced. The comparison of these VOCs with VOCs from single ALB samples (beetles and larvae) published by Makarow et al. (Makarow et al. 2019) underpinned an ALB-VOC pattern. Finally the distinction between VOCs emitted by native insect species as well as healthy trees leads to some ALBspecific volatiles (see Figure 8).

The detailed results of the native insect species, the healthy trees, the trees with mechanical damage and the trees infested by ALB are given in Table 12 and in the supplementary material. The tables show a list of measured substances (name and CAS number) sorted by class (hydrocarbons (HC), benzoic substances (Benz) and mono- (MT) and sesquiterpenes (ST)). The cross indicates the occurrence of the substance. The tables also show the absolute and relative frequency.

The substances copaene and $\alpha$-cubebene are listed as one substance, due to the very high similarity especially in the mass spectrum. Neither distinction via MS nor by use of standards was possible, because standards for these sesquiterpenes were not available at all. The occurrence and overlay of both substances is also possible.

\subsubsection{Comparison of ALB- infested Acer (by larvae and by ovipositions) and non-ALB stressed Acer in greenhouse}

In Table 12 the substances from ALB-infested Acer, ALB ovipositions on Acer (Makarow et al. 2019) and stressed Acer are shown. The analysis of ALB-infested Acer (by larvae) showed 73 substances and with (+)-cyclosativene, one substance that occurs in over $50 \%$ of all measurements. Analysis of non-ALB stressed Acer show 27 substances, none of which occur in at least $50 \%$ of all measurements. 15 substances were emitted by both types of stressed Acer: 9 hydrocarbons (dodecane, hexanal, octane, pentadecane, acetone, heptane, nonanal, hexadecane and tetradecane), 4 monoterpens (1R- $\alpha$-pinene, 3-carene, limonene and $\beta$-pinene), 2 benzoic substances (toluene and benzene). Compared to the results from Makarow et al. from the analysis of ALB ovipositions on Acer under the same greenhouse parameters there are 5 substances, 
that derive from both, ALB infested Acer and ALB ovipositions, on Acer but do not derive from non-ALB stressed Acer: 2,4-dimethyl-1-heptene, camphene, (+)-cyclosativene, copaene, (+)- $\alpha$-longipinene (see Table 12). The analysis of these samples were carried out under comparable environment. The results from Makarow et al. listed in the Table were reduced to the substances, that were detectable in both generations of ALB ovipositions. 
Table 12: Results from the analysis carried out under greenhouse circumstances with "ALB infested Acer": substances detected from ALB infested Acer (43 measurements); "ALB ovipositions on Acer": results from Makarow et al. and "stressed Acer": substances detected from Acer stressed by insufficient water and light supply and cut off branches. Substances are sorted by class with HC hydrocarbons, MT monoterpenes, ST sesquiterpenes and Benz benzoic substances.

\begin{tabular}{|c|c|c|c|c|c|c|c|c|c|c|}
\hline \multirow[b]{2}{*}{ Class } & \multirow[b]{2}{*}{ CAS } & \multirow[b]{2}{*}{ Substance } & \multicolumn{2}{|c|}{ ALB-infested Acer } & \multicolumn{4}{|c|}{ ALB Oviposition on Acer* } & \multicolumn{2}{|c|}{ stressed Acer } \\
\hline & & & $\begin{array}{l}\text { Total no. } \\
\text { Of } 43\end{array}$ & Rel. & $\begin{array}{c}\text { Total } \\
\text { no. } \\
\text { of } 86\end{array}$ & Rel. & $\begin{array}{l}\text { no. } \\
\text { of } \\
\text { P1 }\end{array}$ & $\begin{array}{l}\text { no. } \\
\text { of } \\
\text { P2 }\end{array}$ & $\begin{array}{l}\text { Total no. } \\
\text { of } 22\end{array}$ & Rel. \\
\hline $\mathrm{HC}$ & $112-40-3$ & Dodecane & 19 & $44 \%$ & 32 & $37 \%$ & 16 & 16 & 5 & $23 \%$ \\
\hline $\mathrm{HC}$ & $66-25-1$ & Hexanal & 16 & $37 \%$ & 16 & $19 \%$ & 3 & 13 & 5 & $23 \%$ \\
\hline $\mathrm{HC}$ & $19549-87-2$ & 2,4-Dimethyl-1-heptene & 16 & $37 \%$ & 12 & $14 \%$ & 6 & 6 & & \\
\hline $\mathrm{HC}$ & $111-65-9$ & Octane & 15 & $35 \%$ & 47 & $55 \%$ & 25 & 22 & 5 & $23 \%$ \\
\hline $\mathrm{HC}$ & $629-62-9$ & Pentadecane & 13 & $30 \%$ & 24 & $28 \%$ & 21 & 3 & 5 & $23 \%$ \\
\hline $\mathrm{HC}$ & $67-64-1$ & Acetone & 14 & $33 \%$ & & & & & 3 & $14 \%$ \\
\hline $\mathrm{HC}$ & $142-82-5$ & Heptane & 14 & $33 \%$ & & & & & 3 & $14 \%$ \\
\hline $\mathrm{HC}$ & $589-53-7$ & Heptane, 4-methyl- & 14 & $33 \%$ & & & & & & \\
\hline $\mathrm{HC}$ & $124-19-6$ & Nonanal & 13 & $30 \%$ & & & & & 5 & $23 \%$ \\
\hline $\mathrm{HC}$ & $544-76-3$ & Hexadecane & 13 & $30 \%$ & & & & & 5 & $23 \%$ \\
\hline $\mathrm{HC}$ & $629-59-4$ & Tetradecane & 17 & $40 \%$ & & & & & 5 & $23 \%$ \\
\hline $\mathrm{HC}$ & $2213-23-2$ & Heptane, 2,4-diemthyl- & & & 11 & $13 \%$ & 6 & 5 & 4 & $18 \%$ \\
\hline $\mathrm{HC}$ & $2847-72-5$ & Decane, 4-methyl- & & & 12 & $14 \%$ & 5 & 7 & & \\
\hline $\mathrm{HC}$ & $565-75-3$ & Pentane, 2,3,4-trimethyl- & & & 11 & $13 \%$ & 8 & 3 & & \\
\hline $\mathrm{HC}$ & $2216-34-4$ & Octane, 4-methyl- & & & 9 & $10 \%$ & 5 & 4 & & \\
\hline $\mathrm{HC}$ & $17302-27-1$ & Nonane, 2,5- dimethyl- & & & 7 & $8 \%$ & 4 & 3 & & \\
\hline $\mathrm{HC}$ & $7045-71-8$ & Undecane, 2-methyl- & & & 6 & $7 \%$ & 3 & 3 & & \\
\hline $\mathrm{HC}$ & $67-63-0$ & Isopropyl Alcohol & & & & & & & 6 & $27 \%$ \\
\hline $\mathrm{HC}$ & $124-18-5$ & Decane & & & & & & & 3 & $14 \%$ \\
\hline $\mathrm{HC}$ & $17302-28-2$ & Nonane, 2,6-dimethyl- & & & & & & & 3 & $14 \%$ \\
\hline $\mathrm{HC}$ & $1120-21-4$ & Undecane & & & & & & & 3 & $14 \%$ \\
\hline $\mathrm{HC}$ & 629-78-7 & Heptadecane & & & & & & & 3 & $14 \%$ \\
\hline MT & $7785-70-8$ & 1R- $\alpha$-Pinene & 21 & $49 \%$ & 32 & $37 \%$ & 15 & 17 & 5 & $23 \%$ \\
\hline MT & $13466-78-9$ & 3-Carene & 13 & $30 \%$ & 36 & $42 \%$ & 14 & 22 & 5 & $23 \%$ \\
\hline MT & $79-92-5$ & Camphene & 12 & $28 \%$ & 83 & $97 \%$ & 24 & 59 & & \\
\hline MT & $5989-27-5$ & D-Limonene & 9 & $21 \%$ & & & & & 5 & $23 \%$ \\
\hline MT & $127-91-3$ & $\beta$-Pinene & 13 & $30 \%$ & & & & & 4 & $18 \%$ \\
\hline MT & $555-10-2$ & $\beta$-Phellandrene & 10 & $23 \%$ & & & & & & \\
\hline MT & $138-86-3$ & Limonene & & & 40 & $47 \%$ & 8 & 32 & & \\
\hline ST & $22469-52-9$ & (+)-Cyclosativene & 26 & $60 \%$ & 85 & $99 \%$ & 26 & 59 & & \\
\hline ST & $\begin{array}{l}3856-25-5 / \\
17699-14-8\end{array}$ & Copaene/ $\alpha$-Cubebene & 19 & $44 \%$ & 85 & $99 \%$ & 26 & 59 & & \\
\hline ST & 5989-08-02 & (+)- $\alpha$-Longipinene & 11 & $26 \%$ & 86 & $100 \%$ & 27 & 59 & & \\
\hline ST & $87-44-5$ & Caryophyllene & & & 71 & $83 \%$ & 23 & 48 & & \\
\hline ST & $495-60-3$ & Zingiberene & & & 40 & $47 \%$ & 5 & 35 & & \\
\hline ST & $489-40-7$ & a-Gurjunene & & & 20 & $23 \%$ & 10 & 10 & & \\
\hline ST & $475-20-7$ & (+)-Longifolene & & & & & & & 3 & $14 \%$ \\
\hline Benz & $108-88-3$ & Toluene & 16 & $37 \%$ & 26 & $30 \%$ & 20 & 6 & 5 & $23 \%$ \\
\hline Benz & $644-30-4$ & $\begin{array}{l}\text { Benzene, 1-(1,5-dimethyl- } \\
\text { 4-hexen-1-yl)4-methyl- }\end{array}$ & 10 & $23 \%$ & & & & & & \\
\hline Benz & $71-43-2$ & Benzene & 16 & $37 \%$ & & & & & 4 & $18 \%$ \\
\hline Benz & 24157-81-1 & $\begin{array}{l}\text { 2.6- } \\
\text { Diisopropylnaphthalene }\end{array}$ & & & 32 & $37 \%$ & 24 & 8 & 3 & $14 \%$ \\
\hline Benz & $108-67-8$ & Benzene, 1,3,5-trimethyl- & & & 11 & $13 \%$ & 7 & 4 & & \\
\hline Benz & $719-22-2$ & $\begin{array}{l}\text { 2,5-Cyclohexadiene-1,4- } \\
\text { dione, 2,6-Di-tert-Butyl- }\end{array}$ & & & & & & & 5 & $23 \%$ \\
\hline Benz & $106-42-3$ & P-Xylene & & & & & & & 4 & $18 \%$ \\
\hline Benz & $128-37-0$ & Butylated Hydroxytoluene & & & & & & & 4 & $18 \%$ \\
\hline
\end{tabular}




\subsubsection{Overlap of ALB-infestation and ALB-samples}

Makarow et al. analysed the airborne VOCs from ALB larva, imago and oviposition. They pointed out that 2,5-dimethyl-1-heptene and (+)-cyclosativene were present in all three sample types. This work shows that they were also detectable from ALB-infested Acer in $60 \%$ and $14 \%$, respectively, of all measurements. Furthermore, copaene was suggested to be a marker for infested trees. As $44 \%$ of 43 measurements on infested Acers show copaene, this observation can be endorsed considering a high variation in biological samples. 
Table 13: List of substances determined from a TD-GC/MS analysis from ALB-infested Acer. Only substances that occur in at least $20 \%$ of all measurements are shown. The substances are sorted by class and rate. The numbering in the first column is according to the complete substance-list, which can be seen in the supplemental materials. The substances are sorted by class (HC hydrocarbons, MT monoterpens, ST sesquiterpenes, Benz benzoic substances) and rate ('total no. of 43').

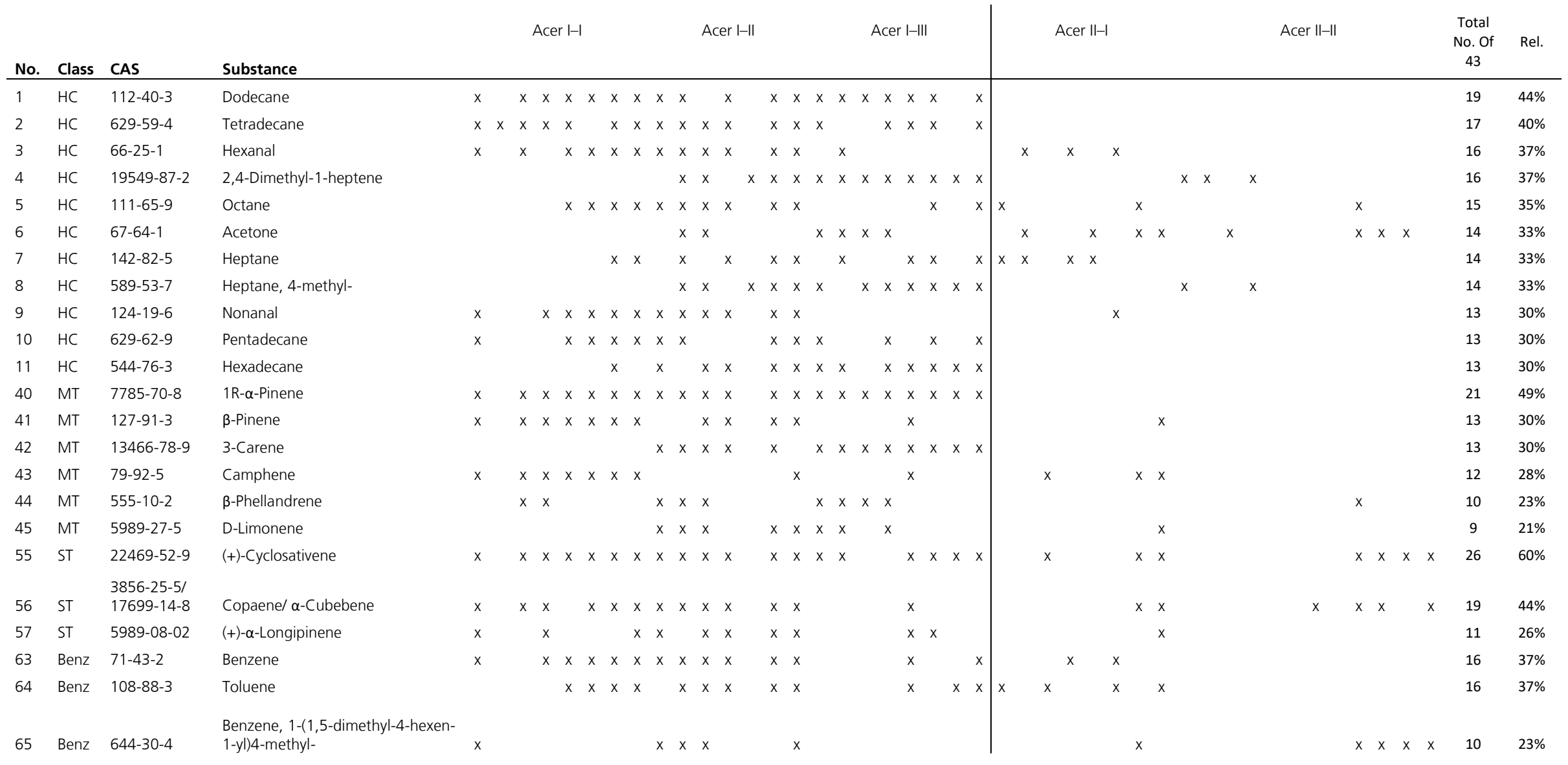




\subsubsection{Comparison to healthy trees in open-land}

With regards to the need of detecting ALB in an open land scenario, the chemical background of an open land infestation was analysed. That was realised by the analysis of ALB preferred healthy host trees (Salix, Populus, Acer) in open land in a tree nursery. As a result, 42 substances were detected, 9 (6 hydrocarbons, toluene and 1R- $\alpha$-pinene and (+)- $\beta$-pinene) of them in more than $50 \%$ or all measurements.

Compared to the analysis of trees presented in chapter 3.4.1 12 substances occur in all three tree-samples: 8 hydrocarbons (heptane, octane, nonanal, dodecane, tetradecane, pentadecane, hexadecane, heptadecane), 2 monoterpenes (1R- $\alpha$-pinene, $\beta$-pinene) and 2 benzoic substances (benzene, toluene). 11 substances ( 6 hydrocarbons, 3 -carene and 4 benzoic substances) were not detectable from healthy trees, but from the group of stressed trees (from ALB-infestation and non-ALB stress).

The three types of healthy trees (Acer, Populus, Salix) show significant differences in their emission of VOCs, especially with regards to sesquiterpenes. With the exception of (-)-alloaromadendrene, which only occurs from Populus and sesquiterpenes, which only derive from Salix. Among them are copaene, $(+)$-cyclosativene and caryophyllene with an occurrence of $100 \%, 78 \%$ and $67 \%$, respectively, in Salix measurements.

It is also noticeable that healthy trees show a stable emission of octane (100\% for Acer, $73 \%$ for Populus and $100 \%$ for Salix) that reduces in case of stress (35\% for ALB-infested Acer, $55 \%$ for Acer with ALB oviposition (Makarow et al. 2019), 23 \% for non-ALB stressed Acer).

\subsubsection{Distinction ALB and other VOC-Sources}

To ensure the detected VOCs originate from the ALB infestation and not from other insect species, the analysis of some native insect species were carried out. The analysis of some native species shown in the supplemental material (species and its sample type) result in altogether 27 substances: 20 hydrocarbons, 6 benzoic substances and, with (+)-longifolene, one sesquiterpene. With regard to the VOC-emission of ALBinfested trees and standalone ALB-material from Makarow et al., Table 14 shows that native species, as well as all ALB samples, emit 2,4-dimethyl-1-heptene and dodecane.

An overview of the most relevant substances with a reliable occurrence over all sample types is given in Table 14. That table shows the comparison between ALB-samples and non-ALB-samples.

\subsection{Discussion}

This work showed that the Identification of Anoplophora glabripennis (Moschulsky) by its emitted specific volatile organic compounds is possible. The approach of extraction volatiles by comparison of infested trees, non-ALB stressed trees, ALB samples in different development stages, native species and healthy trees enabled the successful identification of the specific ALB VOCs. 
Based on the results of Makarow et al. that copaene in combination with (+)-cyclosativene and 2,4-dimethyl1-heptene hint at ALB, this work showed that these ALB originated VOCs are also present and detectable in the ambient air of a living tree that is infested with ALB.

Concerning samples that were taken right on a trunk, we were able to show that the named VOCs do not origin from the stress of a tree in general, as cut and undersupplied Acers do not show these VOCs. But copaene and (+)-cyclosativene are emitted by healthy Salix as well as (+)- $\alpha$-longipinene and caryophyllene. Healthy Acer and Populus did not or rarely show these substances. Qualitatively an interference between ALB-infested trees and Salix is possible.

Makarow et al. showed with a literature research that the named substances were not yet detected from insects. For a more reliable exclusion of cross sensitivities we were able to show that there was no detectable emission of copaene and (+)-cyclosativene among some native species. Whereas 2,4-dimethyl-1-heptene was detectable from Saperda cacharias pupa and Cossus cossus larva.

Although, $44 \%$ occurrence of copaene in infested trees seems to be of moderate statistical proof, the biological variance needs to be taken into account. Among all 23 measurements of Acer-l the occurrence of copaene is with $57 \%$ almost double compared to all Acer-II measurements with $30 \%$ occurrence. As this occurrence gap can be observed over all emitted VOCs (286 in all 23 Acer-I analysis; 55 in all 20 AcerII analysis) it's most likely that Acer-II was analysed under different biological circumstances than Acer-I, although the parameters of light, temperature and humidity were kept constant. As the influences on trees' VOC emission is not yet known it is not possible to control or predict the biological sample and its environmental impacts. By contrast, there is no occurrence of copaene at all for non-ALB stressed Acer or native insect species.

To sum it up, the presence of copaene, (+)-cyclosativene and (+)- $\alpha$-longipinene gives a very strong hint to an ALB-infestation especially if the suspicious tree is not of the type Salix. If the host tree is of the type Salix, then the addition of 2,4-dimethyl-1-heptene and 3-carene could specify the VOC pattern toward ALB. Considering the high biological variance of $\mathrm{VOC}$ emission multiple measurements of a suspicious tree must be acquired to clarify an ALB-infestation without cutting off the tree.

These findings offer the basis for the development of early stage detection technologies of quarantine pests. The clarification of airborne substances offers the opportunity of an improved detection due to better availability and accessibility in air than for physical investigation methods e.g. DNS-sequencing. This is particularly relevant as the threat of invasive alien species is predicted to aggravate in the future (Bradshaw et al. 2016). 
Table 14: List of substances that occur in at least $50 \%$ of one of the ALB-batches in comparison to other possible VOC sources. The numbers indicate the occurrence of the substance in each sample batch in percentage. Starred data originates from Makarow et al. (Makarow et al. 2019).

\begin{tabular}{|c|c|c|c|c|c|c|c|c|c|c|c|}
\hline \multirow[b]{3}{*}{ Class } & \multirow[b]{3}{*}{ CAS } & \multirow[b]{3}{*}{ Substance } & \multicolumn{4}{|c|}{ VOCs from ALB Sources } & \multicolumn{5}{|c|}{ Other Sources } \\
\hline & & & \multirow{2}{*}{$\begin{array}{c}\text { Infested } \\
\text { tree }\end{array}$} & \multirow[b]{2}{*}{ Oviposition* } & \multirow[b]{2}{*}{ Larva* } & \multirow[b]{2}{*}{ Beetle* } & \multicolumn{3}{|c|}{ Healthy tree, open land } & \multirow{2}{*}{$\begin{array}{c}\text { mechanically } \\
\text { damaged } \\
\text { tree }\end{array}$} & \multirow[b]{2}{*}{ native } \\
\hline & & & & & & & Acer & Populus & Salix & & \\
\hline ST & $22469-52-9$ & (+)-Cyclosativene & 60 & 99 & 91 & 23 & - & - & 67 & - & - \\
\hline ST & 5989-08-02 & $(+)-\alpha$-Longipinene & 26 & 100 & 14 & - & - & - & 56 & - & - \\
\hline ST & $\begin{array}{l}3856-25-5 / \\
17699-14-8\end{array}$ & Copaene/ $\alpha$-Cubebene & 44 & 99 & 77 & 31 & - & 9 & 89 & - & - \\
\hline ST & $87-44-5$ & Caryophyllene & 9 & 83 & - & 62 & - & - & 78 & - & - \\
\hline $\mathrm{HC}$ & $111-65-9$ & Octane & 35 & 55 & - & - & 100 & 73 & 100 & 23 & - \\
\hline $\mathrm{HC}$ & 19549-87-2 & 2,4-Dimethyl-1-heptene & 37 & 6 & 59 & 69 & - & - & - & - & 16 \\
\hline $\mathrm{HC}$ & $112-40-3$ & Dodecane & 44 & 16 & 50 & 62 & 43 & - & 33 & 23 & 26 \\
\hline MT & $138-86-3$ & Limonene & & 32 & 95 & - & 14 & - & 22 & & - \\
\hline MT & $7785-70-8$ & 1R- $\alpha$-Pinene & 49 & 17 & 32 & 100 & 43 & 100 & 100 & 23 & - \\
\hline MT & $13466-78-9$ & 3-Carene & 16 & 22 & - & 54 & - & - & - & 23 & - \\
\hline MT & $79-92-5$ & Camphene & 28 & 97 & - & - & 14 & 36 & 89 & - & - \\
\hline
\end{tabular}

\subsection{ACKNOWLedgement}

The results were obtained within a funded research project financed by the Ministry for Environment, Agriculture, Conservation and Consumer Protection of the State of North Rhine-Westphalia ('Ministerium für Umwelt, Landwirtschaft, Natur- und Verbraucherschutz des Landes Nordrhein-Westfalen'). It was supported by Gerhard Renker and Dr. Reiner Schrage from the plant protection service in North Rhine-Westphalia, who managed to build up an ALB breed and supported with entomological expertise.

\section{Author contribute statement}

R. Makarow wrote the manuscript text, prepared all figures and tables and acquired and evaluated almost all data, with the exception of the data of healthy trees (Acer, Salix, Populus), which were acquired by S. Schäfer. All authors reviewed the manuscript.

\section{Competing interests}

The authors declare no competing interests.

\section{Data Availability}

The data generated and analysed during the current study are included in this published article and its Supplementary Information files. 


\subsection{REFERENCES}

Acosta, André L.; Giannini, Tereza C.; Imperatriz-Fonseca, Vera L.; Saraiva, Antonio M. (2016): Worldwide Alien Invasion: A Methodological Approach to Forecast the Potential Spread of a Highly Invasive Pollinator. In: PloS one 11 (2), e0148295. DOI: 10.1371/journal.pone.0148295.

Bidinger, Kerstin (2012): Schadpotenzial gebietsfremder, invasiver Käferarten unter Berücksichtigung des globalen Klimawandels und rechtlicher Aspekte. Online verfügbar unter https://ubt.opus.hbznrw.de/frontdoor/index/index/docld/544.

Boedeker, Enole; Friedel, Godehard; Walles, Thorsten (2012): Sniffer dogs as part of a bimodal bionic research approach to develop a lung cancer screening. In: Interactive CardioVascular and Thoracic Surgery (14), S. 511-514. Online verfügbar unter 10.1093/icvts/ivr070.

Bradshaw, Corey J. A.; Leroy, Boris; Bellard, Céline; Roiz, David; Albert, Céline; Fournier, Alice et al. (2016): Massive yet grossly underestimated global costs of invasive insects. In: Nature communications 7, S. 12986. DOI: 10.1038/ncomms12986.

DeGreeff, Lauryn E.; Furton, Kenneth G. (2011): Collection and identification of human remains volatiles by non-contact, dynamic airflow sampling and SPME-GC/MS using various sorbent materials. In: Anal Bioanal Chem (401), S. 1295-1307. Online verfügbar unter 10.1007/s00216-011-5167-0.

Elliker, Kevin R.; Sommerville, Barbara A.; Broom, Donald M.; Neal, David E.; Armstrong, Sarah; Wiliams, Hywel C. (2014): Key considerations for the experimental training and evaluation of cancer odour detection dogs: lessons learnet from a double-blind, controlled trial of prostate cancer detection. In: BMC Urology (14-22). Online verfügbar unter 10.1186/1471-2490-14-22.

Fischer-Tenhagen, C.; Theby, V.; Krömker, V.; Heuwieser, W. (2018): Detecting Staphylococcus aureus in milk from dairy cows using sniffer dogs. In: Journal of Dairy Science 101 (5), S. 4317-4324. DOI: 10.3168/jds.2017-14100.

Furton, Kenneth G.; Caraballo, Norma Iris; Cerreta, Michelle M.; Holness, Howard K. (2015): Advances in the use of odour as forensic evidence through optimizing and standardizing instruments and canines. In: Philosophical Transactions: Biological Sciences 370 (1674), S. 1-13. Online verfügbar unter http://www.jstor.org/stable/24505154.

Guerrero-Flores, Héctor; Apresa-García, Teresa; Garay-Villar, Ónix; Sánchez-Pérez, Alejandro; FloresVillegas, David; Bandera-Calderón, Artfy et al. (2017): A non-invasive tool for detecting cervical cancer odor by trained scent dogs. In: BMC cancer 17 (1), S. 79. DOI: 10.1186/s12885-016-2996-4.

Hackner, Klaus; Errhalt, Peter; Mueller, Michael Rolf; Speiser, Manulea; Marzluf, Beatrice A.; Schulheim, Andrea et al. (2016): Canine scent detection for the diagnosis of lung cancer in a screening-like situation. In: Journal of Breath Research 10 (4), S. 46003. DOI: 10.1088/1752-7155/10/4/046003.

JKI, Institut für nationale und internationale Angelegenheiten der Pflanzengesundheit (2016): Notfallplan und Leitlinie zur Bekämpfung von Anoplophora glabripennis in Deutschland. In: Bundesanzeiger (BAnz AT 
10.01.2017 B5), S. 1-82. Online verfügbar unter https://www.juliuskuehn.de/media/Neroeffentlichungen/Bekanntmachungen/019_BAnz_AT_10.01.2017_B5_Leitlinie_ALB.p df.

Makarow, Ramona; Schäfer, Sara; Albrecht, Stephan; Robert, Simon; Schütz, Stefan; Kaul, Peter (2019): Investigation of volatile organic compounds emitted by Anoplophora glabripennis (Moschulsky) using thermal desorption and gas chromatography-mass spectrometry. In: Microchemical Journal 146, S. $142-$ 148. DOI: 10.1016/j.microc.2018.12.036.

Marchal, Sophie; Bregeras, Olivier; Puaux, Didier; Gervais, Rémi; Ferry, Barbara (2016): Rigorous Training of Dogs Leads to High Accuracy in Human Scent Matching-To-Sample Performance. In: PloS one (11(2)). Online verfügbar unter 10.1371/journal.pone.0146963.

Mills, Georgina (2018): Sniffer dogs to help combat wildlife crime. In: The Veterinary record 183 (12), S. 370-371. DOI: 10.1136/vr.k4089.

Panebianco, Concetta; Kelman, Edgar; Vene, Kristel; Gioffreda, Domenica; Tavano, Francesca; Vilu, Raivo et al. (2018): Cancer sniffer dogs: how can we translate this peculiarity in laboratory medicine? Results of a pilot study on gastrointestinal cancers. In: Clinical Chemistry and Laboratory Medicine (CCLM) 56 (1). DOI: 10.1515/cclm-2016-1158.

Schallschmidt, Kristin; Becker, Roland; Jung, Christian; Bremser, Wolfram; Walles, Thorsten; Neudecker, Jens et al. (2016): Comparison of volatile organic compounds from lung cancer patients and healthy controls-challenges and limitations of an observational study. In: Journal of Breath Research 10 (4), S. 46007. DOI: 10.1088/1752-7155/10/4/046007.

Seo, In-Seok; Lee, Hwan-Gon; Koo, Bonkon; Koh, Chin Su; Park, Hae-Yong; Im, Changkyun; Shin, HyungCheul (2018): Cross detection for odor of metabolic waste between breast and colorectal cancer using canine olfaction. In: PloS one 13 (2), e0192629. DOI: 10.1371/journal.pone.0192629.

Trotter, R. Talbot; Keena, Melody A. (2016): A Variable-Instar Climate-Driven Individual Beetle-Based Phenology Model for the Invasive Asian Longhorned Beetle (Coleoptera: Cerambycidae). In: Environmental entomology 45 (6), S. 1360-1370. DOI: 10.1093/ee/nvw108.

Willis, Carolyn M.; Britton, Lezlie E.; Harris, Rob; Wallace, Joshua; Guest, Claire M. (2010): Volatile organic compounds as biomarkers of bladder cancer: Sensitivity and specificity using trained sniffer dogs. In: Cancer biomarkers : section A of Disease markers 8 (3), S. 145-153. DOI: 10.3233/CBM-2011-0208.

Xu, Tian; Yasui, Hiroe; Teale, Stephen A.; Fujiwara-Tsujii, Nao; Wickham, Jacob D.; Fukaya, Midori et al. (2017): Identification of a male-produced sex-aggregation pheromone for a highly invasive cerambycid beetle, Aromia bungii. In: Scientific reports 7 (1), S. 7330. DOI: 10.1038/s41598-017-07520-1. 
3.8 SUPPLEMENTAL MATERIAL 
Table 15: List of substances determined from a TD-GC/MS analysis from healthy Acer, Populus and Salix. Substances are sorted by class (HC hydrocarbons, Benz benzoic substances, MT monoterpenes, ST sesquiterpenes) and rate ('total no. of 27').

\begin{tabular}{|c|c|c|c|c|c|c|c|c|c|c|c|c|c|c|c|c|c|c|c|c|c|c|c|c|c|c|c|c|c|c|c|}
\hline \multirow[b]{2}{*}{ Class } & \multirow[b]{2}{*}{ CAS-No. } & \multirow[b]{2}{*}{ Substance } & \multicolumn{7}{|c|}{ Acer } & \multicolumn{11}{|c|}{ Populus } & \multicolumn{9}{|c|}{ Salix } & \multirow{2}{*}{$\begin{array}{c}\text { Total } \\
\text { no. of } \\
27\end{array}$} & \multirow{2}{*}{ Rel. } \\
\hline & & & 1 & 2 & 3 & 4 & 5 & 6 & 7 & 1 & 2 & 3 & 4 & 5 & 6 & 7 & 8 & 9 & 10 & 11 & 1 & 2 & 3 & 4 & 5 & 6 & 7 & 8 & 9 & & \\
\hline C & $000111-65-9$ & Octane & $x$ & $x$ & $x$ & $x$ & $x$ & $x$ & $x$ & $x$ & $x$ & $x$ & $x$ & $x$ & $x$ & $x$ & $x$ & & & & $x$ & $x$ & $x$ & $x$ & $x$ & $\mathrm{x}$ & $x$ & $x$ & $x$ & 24 & $89 \%$ \\
\hline AC & 000629-59-4 & Tetradecane & $x$ & $x$ & $x$ & $x$ & $x$ & $x$ & $x$ & $\mathrm{x}$ & & $x$ & $x$ & & $\mathrm{x}$ & $\mathrm{x}$ & $x$ & $x$ & $x$ & $x$ & $x$ & $x$ & & $x$ & $x$ & $x$ & $x$ & $x$ & $x$ & 24 & $89 \%$ \\
\hline AC & $000629-62-9$ & Pentadecane & $x$ & $x$ & $x$ & $x$ & $x$ & $x$ & $x$ & $\mathrm{x}$ & & & $x$ & $x$ & $x$ & $x$ & $x$ & $x$ & $x$ & $x$ & & $x$ & $x$ & $x$ & $x$ & $x$ & $x$ & $x$ & $x$ & 24 & $89 \%$ \\
\hline †C & $000111-84-2$ & Nonane & $x$ & $x$ & $x$ & $x$ & $x$ & $x$ & & & $x$ & $x$ & $x$ & $x$ & $x$ & $x$ & $x$ & & & & $x$ & $x$ & $x$ & $x$ & $x$ & $\mathrm{x}$ & $x$ & & $x$ & 21 & $78 \%$ \\
\hline †C & 000629-78-7 & Heptadecane & & & & $x$ & $x$ & & & $x$ & & & & $x$ & & $x$ & $x$ & $x$ & $\mathrm{x}$ & $\mathrm{x}$ & $x$ & $x$ & $x$ & $x$ & $x$ & & $x$ & $x$ & $x$ & 17 & $63 \%$ \\
\hline$C$ & $000629-50-5$ & Tridecane & $x$ & $x$ & $x$ & $x$ & $x$ & $x$ & $x$ & & & $x$ & & $x$ & $x$ & & $\mathrm{x}$ & $x$ & $x$ & $x$ & & & & & $x$ & & $x$ & & & 16 & $59 \%$ \\
\hline IC & 000124-19-6 & Nonanal & $x$ & & & & $x$ & $x$ & $x$ & & & $x$ & & & & & & & & & $x$ & $x$ & & $x$ & $x$ & & $x$ & $x$ & & 11 & $41 \%$ \\
\hline C & $000112-31-2$ & Decanal & $x$ & $x$ & & & $x$ & $x$ & $x$ & & & & $x$ & & & & & & & & & & & & & & $x$ & $x$ & $x$ & 9 & $33 \%$ \\
\hline C & 000544-76-3 & Hexadecane & & & & & & & & & & & $x$ & & & & $x$ & $x$ & $x$ & $x$ & & & & & $x$ & & $x$ & $x$ & $x$ & 9 & $33 \%$ \\
\hline C & $000142-82-5$ & Heptane & $x$ & & & & & & & $x$ & & $x$ & $x$ & & & $x$ & & & & & & & & $x$ & & $x$ & & & & 7 & $26 \%$ \\
\hline$c$ & $000111-66-0$ & 1-Octene & $x$ & $x$ & & & $x$ & & & & & & & & & & & & & & & $x$ & $x$ & $x$ & $x$ & & & & & 7 & $26 \%$ \\
\hline C & $000124-11-8$ & 1-Nonene & $x$ & $x$ & & & $x$ & & & & & & & & & & & & & & & $x$ & $x$ & $x$ & $x$ & & & & & 7 & $26 \%$ \\
\hline †C & 001120-36-1 & 1-Tetradecene & $x$ & $x$ & $x$ & $x$ & $x$ & $x$ & $x$ & & & & & & & & & & & & & & & & & & & & & 7 & $26 \%$ \\
\hline$C$ & 021964-49-8 & 1,13-Tetradecadiene & $x$ & $x$ & $x$ & $x$ & $x$ & $x$ & $x$ & & & & & & & & & & & & & & & & & & & & & 7 & $26 \%$ \\
\hline C & $000112-40-3$ & Dodecane & & $x$ & & $x$ & & $x$ & & & & & & & & & & & & & $x$ & & $x$ & $x$ & & & & & & 6 & $22 \%$ \\
\hline$C$ & 002437-56-1 & 1-Tridecene & $x$ & $x$ & $x$ & $x$ & $x$ & $x$ & & & & & & & & & & & & & & & & & & & & & & 6 & $22 \%$ \\
\hline$C$ & 006765-39-5 & 1-Heptadecene & & $x$ & & $x$ & $x$ & $x$ & $x$ & & & & & & & & & & & & & & & & & & & & & 5 & $19 \%$ \\
\hline HC & 013360-61-7 & 1-Pentadecene & & $x$ & & & $x$ & $x$ & & & & & & & & & & & & & & & & & $x$ & & & & & 4 & $15 \%$ \\
\hline$c$ & $000592-27-8$ & Heptane, 2-methyl- & & & & & & & & & & & & & & & & & & & & $x$ & $x$ & $x$ & & & & & & 3 & $11 \%$ \\
\hline C & $000821-95-4$ & 1-Undecene & & $x$ & $x$ & $x$ & & & & & & & & & & & & & & & & & & & & & & & & 3 & $11 \%$ \\
\hline$\dashv C$ & $000112-41-4$ & 1-Dodecene & & $x$ & & $x$ & & & & & & & & & & & & & & & & & & $x$ & & & & & & 3 & $11 \%$ \\
\hline -C & 000629-73-2 & 1-Hexadecene & & & & $x$ & $x$ & $x$ & & & & & & & & & & & & & & & & & & & & & & 3 & $11 \%$ \\
\hline enz & 000108-88-3 & Toluene & $x$ & $x$ & & & & & $x$ & $x$ & $x$ & $x$ & $x$ & $x$ & $x$ & $x$ & $x$ & $x$ & $x$ & $x$ & $x$ & $x$ & & $x$ & & $\mathrm{x}$ & $x$ & $x$ & $x$ & 21 & $78 \%$ \\
\hline enz & 004536-86-1 & Benzene, (1-propyloctyl)- & & & & & & & & & & & $x$ & & & & & & & & $x$ & $x$ & $x$ & $x$ & $x$ & $x$ & & $x$ & $x$ & 9 & $33 \%$ \\
\hline enz & 004537-15-9 & Benzene, (1-butylheptyl)- & & & & & & & & & & & $x$ & & & & & & & & $x$ & $x$ & $x$ & $x$ & & $x$ & & $x$ & $x$ & 8 & $30 \%$ \\
\hline enz & $004621-36-7$ & Benzene, (1-ethyloctyl)- & & & & & & & & & & & $x$ & & & & & & & & $x$ & $x$ & $x$ & $x$ & $x$ & $x$ & & & & 7 & $26 \%$ \\
\hline enz & $004536-87-2$ & Benzene, (1-ethylnonyl)- & & & & & & & & & & & $x$ & & & & & & & & $x$ & & $x$ & $x$ & $x$ & $x$ & & & $x$ & 7 & $26 \%$ \\
\hline Benz & $000071-43-2$ & Benzene & & & & & & & & $x$ & & & $x$ & $x$ & & & & $x$ & $x$ & $x$ & & & & & & & & & & 6 & $22 \%$ \\
\hline$n z$ & $004537-12-6$ & Benzene, (1-propylheptyl)- & & & & & & & & & & & $x$ & & & & & & & & $x$ & $x$ & $x$ & $x$ & & $\mathrm{x}$ & & & & 6 & $22 \%$ \\
\hline enz & $004537-11-5$ & Benzene, (1-butylhexyl)- & & & & & & & & & & & & & & & & & & & $x$ & $x$ & $x$ & $x$ & & $x$ & & & & 5 & $19 \%$ \\
\hline VT & 007785-70-8 & 1R- $\alpha$-Pinene & & $x$ & & $x$ & & & $x$ & $x$ & $x$ & $x$ & $x$ & $x$ & $x$ & $x$ & $x$ & $x$ & $x$ & $x$ & $x$ & $x$ & $x$ & $x$ & $x$ & $x$ & $x$ & $x$ & $x$ & 23 & $85 \%$ \\
\hline$M T$ & $000127-91-3$ & $(+)$ - $\beta$-Pinene & & $x$ & & & & & & $x$ & $x$ & & & & $x$ & $x$ & & $x$ & $x$ & $x$ & & $x$ & $x$ & $x$ & $x$ & $x$ & $x$ & $x$ & $x$ & 16 & $59 \%$ \\
\hline MT & $000079-92-5$ & Camphene & & $x$ & & & & & & & & $x$ & & & & & & $x$ & $x$ & $x$ & $x$ & $x$ & $x$ & $x$ & $x$ & & $x$ & $x$ & $x$ & 13 & $48 \%$ \\
\hline ИT & $000464-48-2$ & (-)-Camphor & & & & & & & & & & $x$ & & & & & & $x$ & $x$ & $x$ & & & & & & & & & & 4 & $15 \%$ \\
\hline MT & $000138-86-3$ & Limonene & $x$ & & & & & & & & & & & & & & & & & & $x$ & & & & & $x$ & & & & 3 & $11 \%$ \\
\hline $\mathrm{S}=$ & 017699-14-8 & Copaene/ $\alpha$-Cubene & & & & & & & & & & & $x$ & & & & & & & & $x$ & $x$ & $x$ & $x$ & $x$ & $x$ & $x$ & $x$ & $x$ & 10 & $37 \%$ \\
\hline ST & $000087-44-5$ & Caryophyllene & & & & & & & & & & & & & & & & & & & & $x$ & $x$ & $x$ & $x$ & & $x$ & $x$ & $x$ & 7 & $26 \%$ \\
\hline 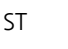 & 017699-05-7 & trans- $\alpha$-Bergamotene & & & & & & & & & & & & & & & & & & & & $x$ & $x$ & $x$ & $\mathrm{x}$ & & $x$ & $x$ & $\mathrm{x}$ & 7 & $26 \%$ \\
\hline & $003691-12-1$ & $\alpha$-Guaiene & & & & & & & & & & & & & & & & & & & & $x$ & $x$ & $\mathrm{x}$ & $x$ & & $x$ & $x$ & $x$ & 7 & $26 \%$ \\
\hline S] & 022469-52-9 & (+)-Cyclosativene & & & & & & & & & & & & & & & & & & & & $x$ & $x$ & $x$ & $x$ & & & $x$ & $x$ & 6 & $22 \%$ \\
\hline$S$ & 5989-08-02 & $(+)-\alpha$-Longipinene & & & & & & & & & & & & & & & & & & & $x$ & $x$ & & $x$ & $x$ & $x$ & & & & 5 & $19 \%$ \\
\hline ST & $25246-27-9$ & (-)-Alloaromadendrene & & & & & & & & & & & & $x$ & & & & $x$ & $x$ & $x$ & & & & & & & & & & 4 & $15 \%$ \\
\hline
\end{tabular}


Table 16: List of substances determined from a TD-GC/MS analysis from non-ALB stressed Acer. Substances are sorted by class (HC hydrocarbons, Benz benzoic substances, MT monoterpenes, ST sesquiterpenes) and rate ('total no. of 22').

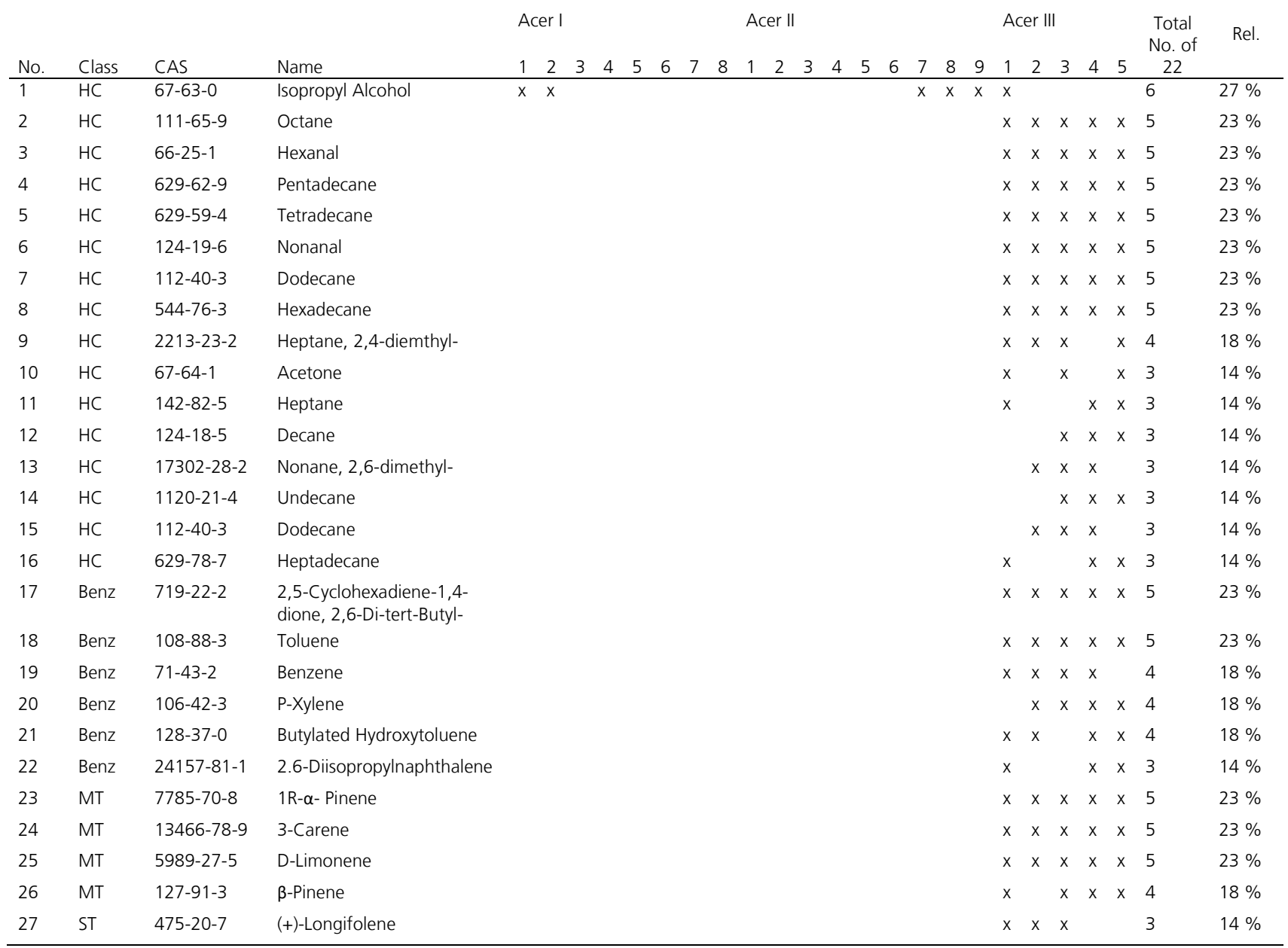




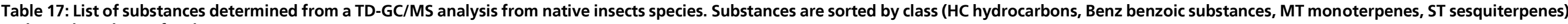
and rate ('total no. of 42 ').

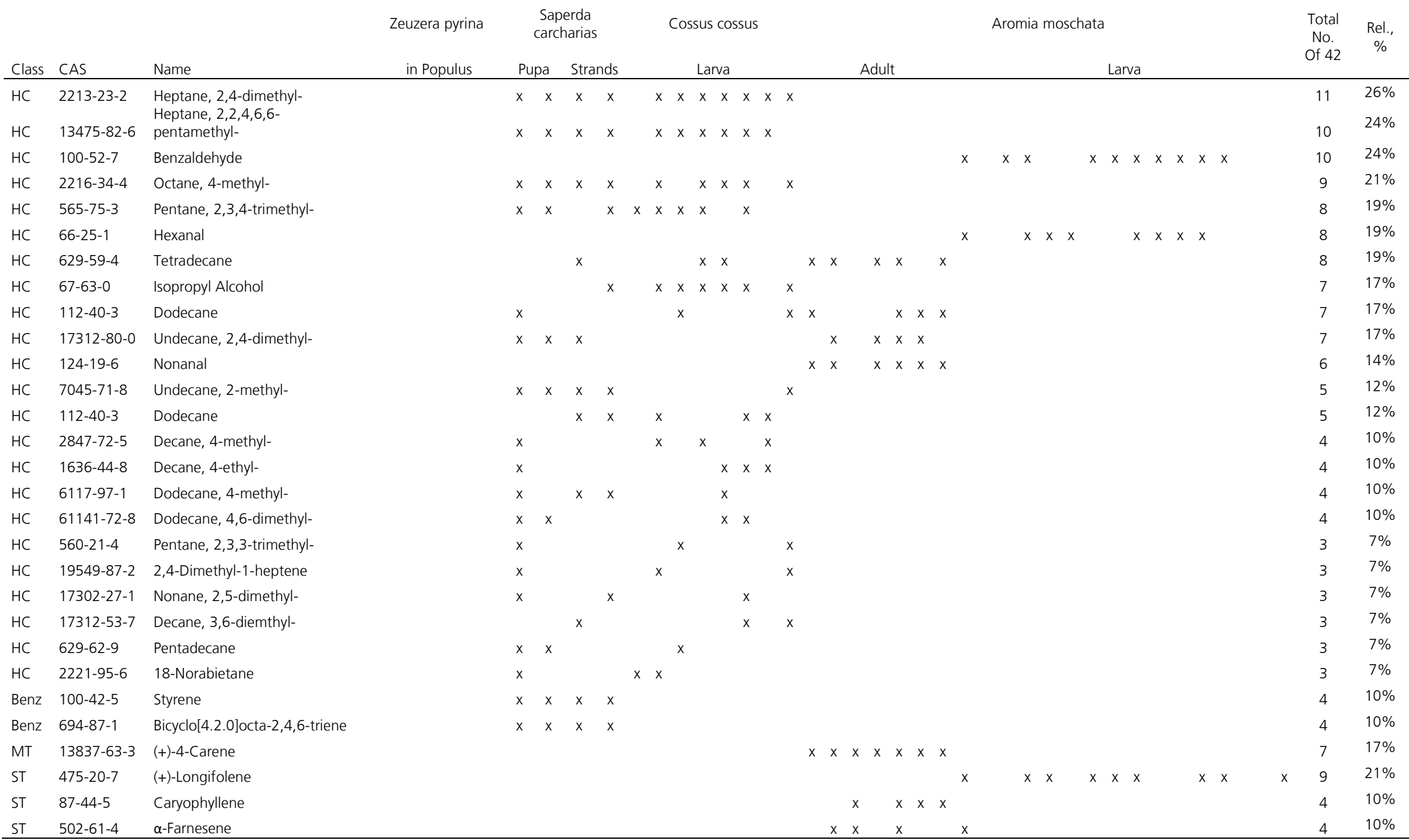




\section{Part III: Behördliche Anforderungen an ALB-Spürhunde-ein Erfahrungsbericht}

Peter Kaul', Ramona Makarow', Frank Nüßer ${ }^{2}$

'Hochschule Bonn-Rhein-Sieg, Institut für Sicherheitsforschung (ISF)

2Bayerische Landesanstalt für Landwirtschaft (LfL)-Institut für Pflanzenschutz (IPS)

Published in the book "Faszinosum Spürhunde-dem Geruch auf der Spur. Tagungsergebnisse des 4. Symposiums für Odorologie im Diensthundewesen"; Editor: Dr. Christine Schüler, Prof. Peter Kaul

ISBN 2510-4365, Verlag Dr. Kovac

\subsection{ABstract}

Bei der Bekämpfung des Asiatischen Laubholzbockkäfers (ALB) werden deutschlandweit und darüber hinaus ALB-Spürhunde eingesetzt. Sie bieten die Möglichkeit der mobilen und ALB-spezifische Suche über größere Flächen bzw. in verschiedensten Suchszenarien. Zuständig für die ALB Bekämpfung sind in der Regel die Pflanzenschutzdienste der Bundesländer, die, sofern sie keine eigenen Hunde besitzen, Aufträge an Dritte per Ausschreibung vergeben. Kriterien für die Vergabe von Aufträgen müssen dabei in den Ausschreibungen eindeutig aufgelistet sein. Ein bedeutendes Merkmal, das die Behörden festschreiben könnten bezieht sich auf die Qualifikation bzw. Leistung, die das Team Hund/Hundeführer nachweisen bzw. erbringen soll. Bisher fehlen eindeutige Kriterien bezüglich Leistung und Qualifikation zur Auswahl der geeigneten Spürhundeteams. Es besteht daher der Wunsch der Behörden nach Sichtung der Teams in situationsbezogenen Einsatzszenarien.

Die Hochschule hat in Kooperation mit dem Pflanzenschutzdienst Bayern und Baden-Württemberg erste Machbarkeitsstudien zur Durchführung von Leistungstests durchführen können, die sich an möglichst realitätsnahen Einsatzszenarien orientiert haben. Im Vortrag werden die Szenarien beispielhaft vorgestellt und die Vor- und Nachteile sowie mögliche Probleme bei der Durchführung diskutiert. 


\subsection{EinLeItung}

In den letzten Jahren nahm die Zahl der gebietsfremden zugewanderten Arten in Europa infolge der Globalisierung und durch Importe aus dem Ausland stetig zu (Scheibner et al. 2015). Dabei kommt den Tier- und Pflanzenarten, die bestehende Ökosysteme sowie die Land- und Forstwirtschaft sowohl ökologisch als auch ökonomisch beeinträchtigen und nachhaltig schädigen, eine besondere Bedeutung zu (Davis 2009). Vor allem für Pflanzenschädlinge gibt es neben internationalen Handelsauflagen für den global vernetzten Warenstrom in verschiedenen Ländern der Erde, rechtlich verbindliche Regelungen zur Vorbeugung des

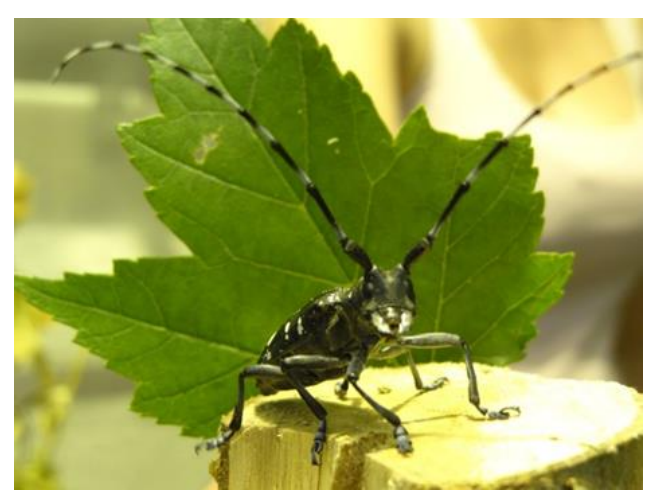

Figure 11: Anoplophora glabripennis Käfer

Gefahrenpotentials. Gerade Pflanzenschadorganismen, die nach Art. ॥ des Internationalen Pflanzenschutzübereinkommens (International Plant Protection Convention - IPPC) „von potentieller wirtschaftlicher Bedeutung für das durch inn gefährdete Gebiet [sind], der in diesem Gebiet noch nicht vorkommt oder zwar schon vorkommt, aber nicht weit verbreitet ist und amtlichen Überwachungs- und Bekämpfungsmaßnahmen unterliegt" (=Quarantäneschadorganismus) sind zu überwachen und zu bekämpfen. Eine in der Europäischen Union nach A/Anhang $\mid$ Quarantäne-RL als Quarantäneschadorganismus eingestufte Insektenart ist der polyphage Aisatische Laubholzbockkäfer (ALB, Anoplophora glabripennis, Motschulsky). Eingeschleppt mit Verpackungshölzern, wie sie z.B. für den Steinguttransport aus Asien verwendet werden, erfolgte der erste Befall 2001 in Europa und 2004 in Deutschland. Der ALB zählt zu den weltweit gefährlichsten invasiven Schädlingen, da er vitale Laubgehölze befällt und durch einen mehrjährigen Befall ihre Leitgefäße beschädigt, so dass die Pflanzen infolge des unterbrochenen Saftstroms, schließlich absterben (Wermelinger et al. 2013). Zudem ist das Wirtspflanzenspektrum mit 29 Arten von Laubbäumen und -sträuchern sehr groß. Allein der wirtschaftliche Schaden, den der Asiatische Laubholzbockkäfer ohne Bekämpfungsmaßnahmen in Deutschland nur an der Baumsorte Ahorn anrichten kann, wird auf 96 Millionen $€$ geschätzt (Schröder 2014). Mit dem Durchführungsbeschluss (EU) 2015/893 vom 9. Juni 2015 hat die Europäische Kommission eine einheitliche Regelung über Maßnahmen zum Schutz der Union gegen die Einschleppung und Ausbreitung von Anoplophora glabripennis erlassen (Europäische Kommission 2015). 


\section{Aufgaben des Pflanzenschutzdienstes in Bayern:}

Für die Umsetzung des EU-Durchführungsbeschlusses sind die Pflanzenschutzdienste der Bundesländer zuständig. In Bayern obliegt diese Aufgabe dem Institut für Pflanzenschutz (IPS) der Landesanstalt für Landwirtschaft (LfL).

Zu den Aufgaben des Pflanzenschutzdienstes zählen die Überwachung und Kontrolle von:

- Einfuhr der spezifizierten Pflanzen in EU

- Einfuhr von spezifiziertem Holz in EU

- Verbringung spezifizierter Pflanzen innerhalb der EU

- Verbringung von spezifiziertem Holz \& von spezifiziertem Holzverpackungsmaterial

- Nationales Monitoring

- Monitoring in abgegrenzten Gebieten (Quarantänezone - QZ).

Wurde das Vorkommen des ALBs in einem Gebiet bestätigt, so muss gemäß dem EUDurchführungsbeschluss ein abgegrenztes Gebiet eingerichtet werden. Wie in der schematischen Darstellung in Figure 12 ersichtlich, besteht das abgegrenzte Gebiet sowohl aus der Befallszone bzw. Fällungszone, als auch aus der Fokus- und Pufferzone. Die Luftbildaufnahme (Quelle LFL) zeigt am Beispiel des Befallsgebietes Feldkirchen die Größe der gesamten Quarantänezone sowie die Abgrenzung der Zonen.
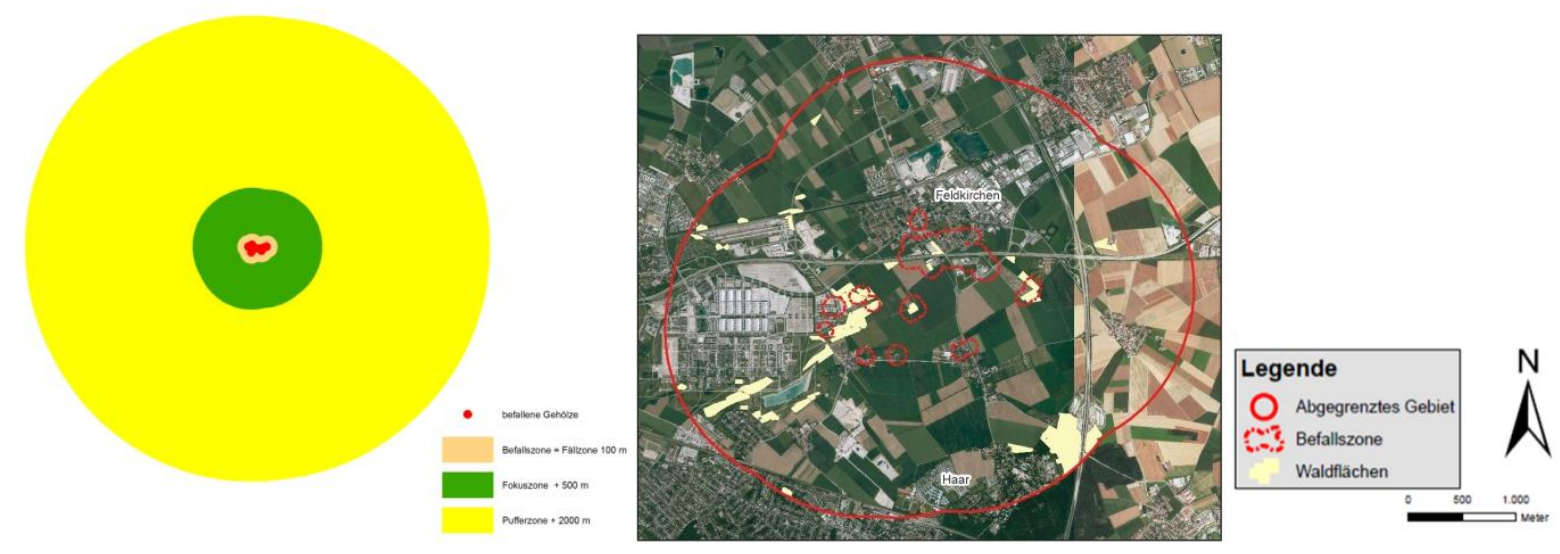

Figure 12: Quarantänezone in Bayern [Quelle: LFL]

Aufgabenschwerpunkt in den Quarantänegebieten ist das Monitoring. Die Monitoringmaßnahmen differenzieren sich dabei in das Boden- und Kronenmonitoring sowie in den Einsatz von Fangbäumen und Pheromonfallen. Zudem finden Gehölzkontrollen bei Fällmaßnahmen sowie destruktiven Probenahmen und bei Verdachtsmeldungen statt.

Ziel dieser Maßnahmen ist es, Stadien des ALB oder Teile davon zu finden, da nur so eine sichere Befallsfeststellung gewährleistet werden kann. Die nachfolgende Abbildung (Figure 13) zeigt beispielhaft die angewendeten Maßnahmen (Quelle Bilder: alle LFL). 


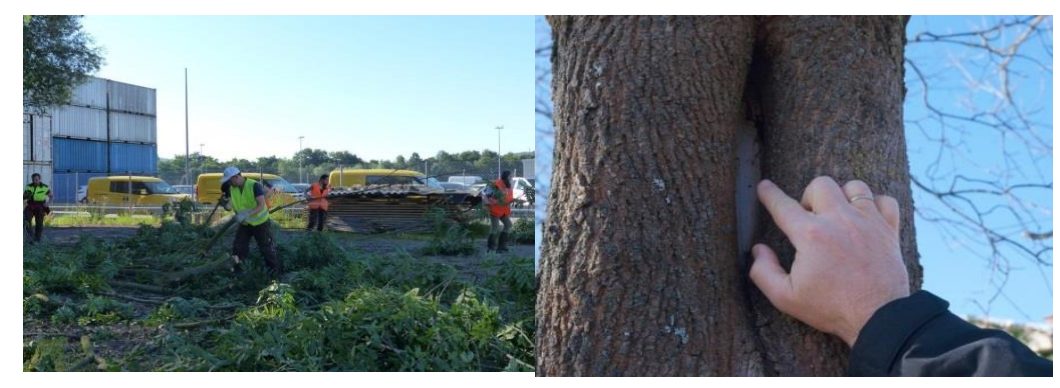

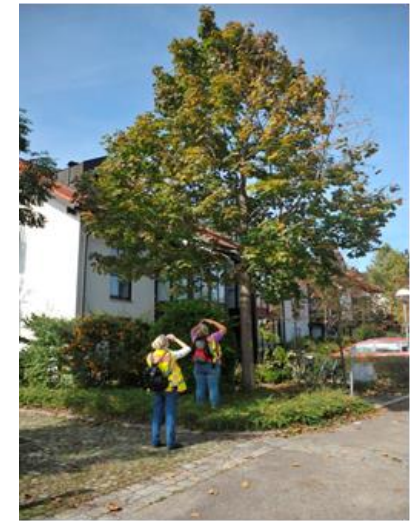

Bodenmonitoring

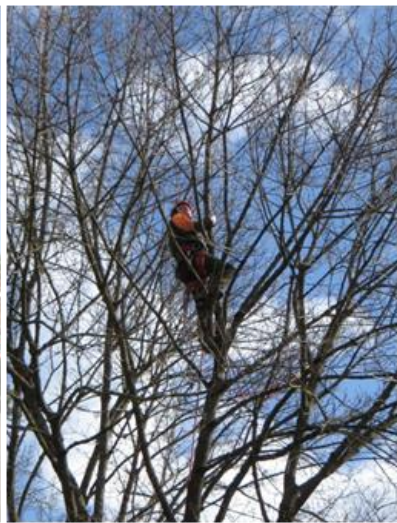

Kronenmonitoring durch Baumkletterer

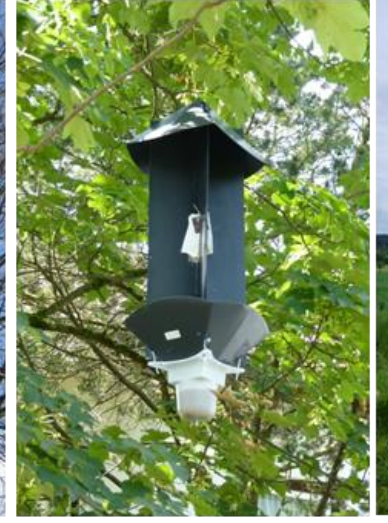

Einsatz von Pheromonfallen

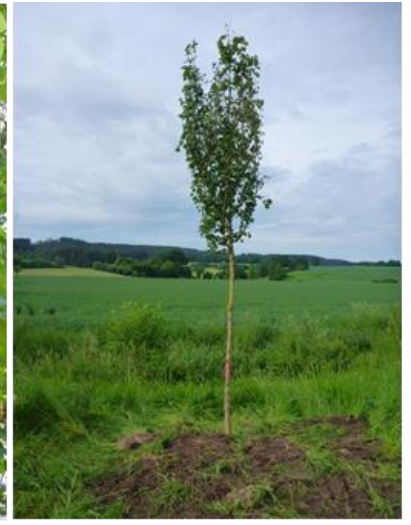

Einsatz von Fangbäumen

Figure 13: Bekämpfungsmaßnahmen bei ALB-Befall in Bayern [Quelle: Frank Nüßer, LFL]

Sowohl der hohe Aufwand als auch die Schwierigkeit die sich bei der Kontrolle unterschiedlicher Vegetationsstrukturen, wie z.B. Feldgehölze mit dichtem Unterwuchs, Brachflächen mit dichten Verjüngungsstrukturen, Heckenstrukturen und Gehölzstrukturen an Uferrandbereichen ergeben, erfordern eine effektivere Durchführung des Monitoringkonzeptes. Aus diesem Grund wurden seitens des bayerischen Pflanzenschutzdienstes zunächst ALB-Spürhundeteams als Dienstleister eingesetzt, die eine Basisausbildung zum zertifizierten Anoplophora-Spürhundeteam durch das Bundesforschungs- und Ausbildungszentrum für Wald, Naturgefahren und Landschaften (BFW) am Institut für Waldschutz in Österreich durchlaufen haben. Die Spürhundeteams wurden ergänzend bei ALB-Fällmaßnahmen, beim Bodenmonitoring und beim Absuchen von Verdachtsbäumen eingesetzt.

Die ersten Erfahrungen beim Einsatz von ALB-Spürhundeteams haben gezeigt:

Positiv:

+ ALB-Anzeige bei lebenden und toten ALB-Stadien (Ei, Larve, Käfer)

+ ALB-Anzeige bei Gangsystemen (auch mehrere Jahre alt \& überwallt)

+ effektivere Kontrolle bei komplexen Gehölzstrukturen (Hecken) sowie befallsverdächtigen Gehölzen

+ Hinweise bei Verdachtsbäumen

+ "Sympathiefaktor" bei der Bevölkerung 
Negativ:

- $\quad$ begrenztes Angebot örtlich vorhandener \& kurzfristig verfügbarer ALB-Spürhundeteams

- begrenzte Suchzeiten der ALB-Spürhunde

- $\quad$ klimatischer Einfluss (Suchleistung)

Dementsprechend besteht seitens der LfL der Bedarf weiterer Anoplophora-Spürhundeteams. Des Weiteren hat sich gezeigt, dass der Pflanzenschutzdienst auch kurzfristig über Anoplophora-Spürhunde verfügen sollte. Folglich verfügt der bayerische Pflanzenschutzdienst über vier Vollzeit- und zwei TeilzeitSpürhundeteams. Im Einsatz sind derzeit (2015) ein Deutsch-Drahthaar (\$), (2016) drei Bayerische Gebirgsschweißhunde (20/19), (2016) ein Mischling (\$), (2017) ein Bretonischer Spaniel (ơ). Da sich die ALB-Spürhunde im Eigentum der Hundeführerin bzw. des Hundeführers befinden und ihr Einsatz auf freiwilliger Basis durch die Hundeführerin bzw. den Hundeführer erfolgt, wurden die Ausbildungskosten zum zertifizierten ALB-Spürhundeteam vollständig vom Freistaat Bayern getragen. Der ALB-Spürhundeeinsatz erfolgt täglich und lässt sich in eine Liegend- und Stehendsuche differenzieren.

Figure 14 zeigt die häufigsten Suchszenarien. Während bei einer Liegendsuche die zu kontrollierenden Gehölze mehr oder wenige ebenerdig auf dem Boden liegen und die Kontrollen bei amtlich angeordneten ALB-Fällungen, bei Gehölzpflegemaßnahmen und beim Verbringen von spezifiziertem Holz erfolgen, findet die Stehendsuche ausschließlich am noch stehenden Gehölz statt. Diese Kontrollvariante ist eine Ergänzungskontrolle beim Monitoring, die Heckenstrukturen, Verjüngungsflächen, Sammelstellen und Pflanzbestände von Baumschulen sowie Kontrollen beim Verbringen spezifizierter Pflanzen umfasst (Quelle Bilder: alle LFL).
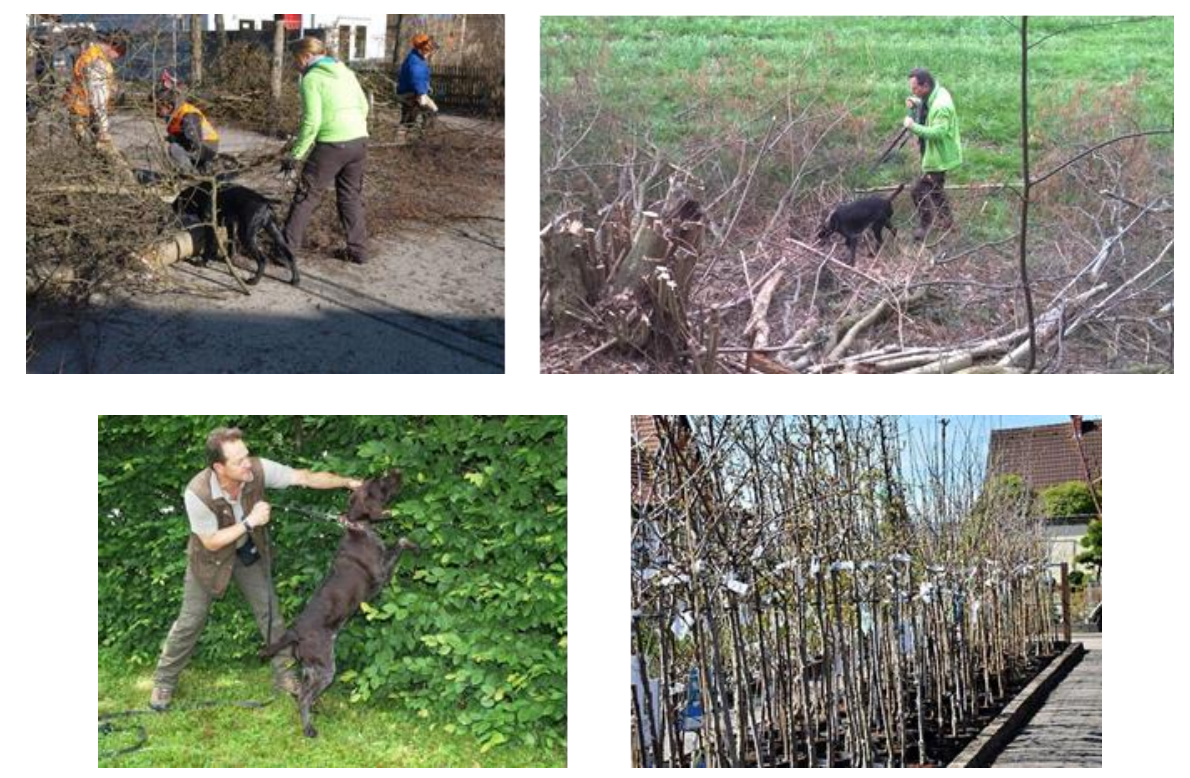

Figure 14: Spürhunde der LfL im Einsatz an verschiedenen Gebieten [Quelle: Frank Nüßer, LFL]

Eingesetzt werden vorwiegend die eigenen bayerischen ALB-Spürhunde, die bei Bedarf aber auch durch ALB-Spürhundedienstleistertätigkeiten ergänzt werden. 
Dementsprechend werden an alle Spürhundeteams die folgenden Anforderungen gestellt:

- eindeutige Positivanzeige lebender ALB-Stadien (Ei, Larve, Käfer)

- eindeutige Positivanzeige toter ALB-Stadien (Ei, Larve, Käfer)

- Detektion bei fehlenden lebenden ALB-Stadien

- Detektion bei visuell nicht eindeutigen Befallssymptomen

- effiziente Ergänzung des Boden- \& Kronenmonitorings

- $\quad$ eigenständige Suche/ Arbeitswille

- körperliche Eignung

- konzentrierte Suche/ Tauglichkeit

- regelmäßiges Training verschiedener Suchszenarien

- punktuelle Suchen \& Flächensuchen

Die Anforderungen gelten dabei sowohl für die eigenen Spürhundeteams als auch für externe Anbieter. Aufträge an Dritte müssen per Ausschreibung vergeben werden. Kriterien für die Vergabe von Aufträgen müssen dabei in den Ausschreibungen eindeutig aufgelistet sein. Ein bedeutendes Merkmal, das die Behörden festschreiben könnten, bezieht sich auf die Qualifikation bzw. Leistung, die das Team Hund/Hundeführer nachweisen bzw. erbringen soll. Eindeutige Kriterien bezüglich Leistung und Qualifikation, die zur Beurteilung geeigneter Spürhundeteams herangezogen werden können, fehlen bisher. Es besteht daher der Wunsch der Behörden nach Sichtung der Teams in situationsbezogenen Einsatzszenarien in Form eines regelmäßig aktualisierten Qualifikationsnachweises über die Leistungsfähigkeit des Spürhundeteams in verschiedenen Suchszenarien. Darüber hinaus wären eine (deutschlandweite) Abfragedatenbank sowie die Erstellung eines Kriterienkataloges für Ausschreibungsunterlagen wünschenswert.

\subsection{QUALIFIKATIONSNACHWEIS VON ALB-SPÜRHUNDEN}

Aus den Anforderungen der Pflanzenschutzdienste hat die Hochschule Bonn-Rhein-Sieg im Rahmen eines Projektes zusammen mit den Pflanzenschutzdiensten in Hamburg, Baden-Württemberg und Bayern erste Konzepte für den geforderten Qualifikationsnachweise erarbeitet und in der Praxis durchgeführt. Am Beispiel der Versuche, die zusammen mit der LfL Bayern und dem Landwirtschaftlichen Technologiezentrum Baden-Württemberg durchgeführt wurden, sollen an dieser Stelle einige Erfahrungen aus diesen Konzepten beschrieben werden.

Anfang April 2018 wurden auf dem Gelände der LfL durch die Hochschule Bonn-Rhein-Sieg einige Suchszenarien vorbereitet und entsprechende Versuchstrecken präpariert. Die Temperaturen und Wetterverhältnisse waren an den drei Versuchstagen moderat, die Temperaturen betrugen zwischen $15^{\circ} \mathrm{C}$ und $20^{\circ} \mathrm{C}$, kein Regen und geringer Wind. Diese Versuchsbedingungen wurden als optimal für die Suche mit ALB-Spürhunden im Freiland angesehen. 
Die nachfolgende Abbildung zeigt eine Aufsicht des zur Verfügung stehenden Geländes der LfL, auf dem eine Freilandsuche möglich war.

\subsubsection{Beschreibung der Versuche}

Die Versuche mit den Hundeteams wurden an zwei Tagen mit insgesamt vier verschiedenen Versuchstrecken (Strecke 1 und 2 am ersten Tag sowie Strecke 3 und 4 am zweiten Tag, Figure 15) durchgeführt. Die genauere Beschreibung der Versuchsstrecken erfolgt in den entsprechenden Kapiteln.

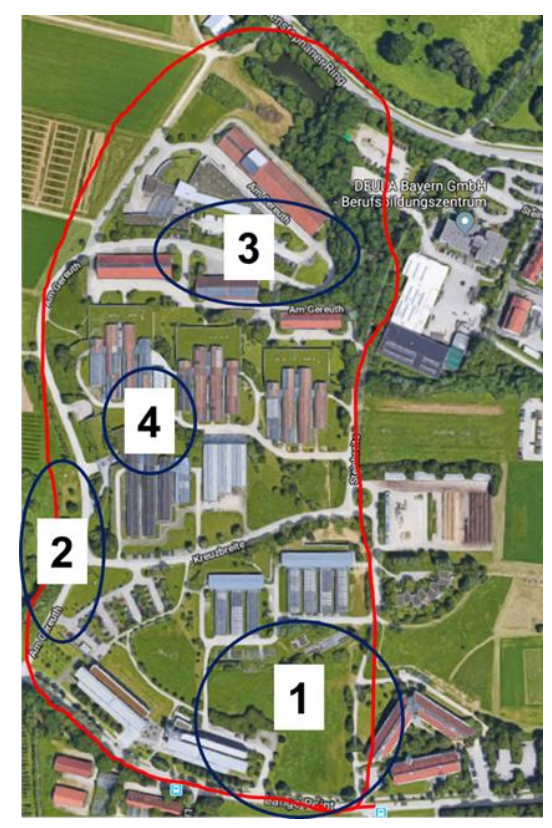

Figure 15: Gelände der LfL mit vier realisierten Suchszenarien

Vor den Versuchen mit den Spürhundeteams fanden bereits halbtägig eine Sichtung des Geländes und vorbereitende Maßnahmen zum Aufbau der Versuchsstrecken statt. Die Versuchsstrecken sollten verschiedene Schwierigkeitsgrade haben, typische Suchszenarien abbilden, nicht zu groß sein, um die Suchzeit nicht zu groß werden zu lassen und für die Hundeteams und die Präparation einigermaßen gut zugänglich zu sein.

Zur Suche wurden verschiedene Geruchsquellen und Verleitungen verwendet. Dies waren freigegebene Holzstücke mit ALB Bohrgängen sowie ähnlich präpariertes nicht befallenes Holz und Geruchsträger mit ALB Geruch, der durch Anreicherung an Befallsbäumen gewonnen wurde, sowie identische Geruchsträger ohne Fremdgerüche, zur Beschreibung dieser Geruchsträger, siehe unten.

Bei der Präparation einiger Strecken wurde vorab oder nach einem Testlauf mit einem bekannten Spürhund geprüft, ob das Auffinden der Proben in den gewählten Szenarien überhaupt möglich und damit die Versuchsstrecke geeignet ist. Aus der Erfahrung aus vorangegangenen ähnlichen Versuchen war bekannt, dass trotz sorgfältiger Planung die Versuchsstrecke aus oftmals unbekannten Gründen nicht geeignet ist und Hunde nicht zur Anzeige kommen. Die Leistungsfähigkeit des eingesetzten Spürhundes war durch die Hochschule aus Vorversuchen bereits eindeutig festgestellt worden. Der Hund ist geruchsdifferenzierend 
ausgebildet, die Kurzzeitkonditionierung bzw. Geruchseingabe erfolgte mithilfe eines Holzstücks, in dem sich Bohrgänge des ALB befanden.

Für die Vorbereitung der Versuchsstrecken sowie für die Durchführung der Sichtung der Suche waren zwei Personen der Hochschule eingesetzt. Es wurde darauf geachtet, dass die Ausbringung der Geruchsträger nur von einer Person vorgenommen wurde, die in den gezeigten Bereichen möglichst viel ohne Geruchträger umherläuft, um den gesamten Bereich mit dem Geruch der Person zu sättigen. Zusätzlich zu den zwei Personen der Hochschule waren ein oder zwei ausgebildete Hundetrainer bei der Sichtung anwesend, die das Suchverhalten der Hunde sowie das Zusammenspiel des Hundeteams begutachtet haben. Auf diese Weise konnten direkt nach der Suche Rückmeldungen an die Hundeteams über Auffälligkeiten sowie Verbesserungsvorschläge erfolgen.

Für die Versuche wurden acht Hundeteams aus Bayern und Baden-Württemberg eingesetzt. Die Hunde waren wie oben beschrieben durch die BFW ausgebildete ALB-Spürhunde, allerdings mit unterschiedlichem Trainingsstand, der vor den Versuchen der Hochschule nicht bekannt war. Die Hundeteams sind nacheinander die Versuchsstrecken durchlaufen, wobei die Versuche als single-blind Versuche durchgeführt wurden, d.h. das jeweilige Hundeteam wusste nicht, wo die Probe versteckt war. Es sei an dieser Stelle angemerkt, dass die single-blind Suche nur eingeschränkt möglich war, da einige Hundeführer zwei Hunde führten und die Anzeige des ersten Hundes kannten. Zudem kann von einem Informationsausstausch unter den Hundeführern ausgegangen werden.

Im Folgenden werden die verschiedenen Suchszenarien beschrieben, aus denen sich die am Ende aufgelisteten Erfahrungen und Empfehlungen ableiten lassen. Es ist in diesem Beitrag nicht Ziel, die Qualifizierungen und Ergebnisse der einzelnen Hundeteams aufzulisten, die Daten sind daher in diesem Bericht bewusst weggelassen worden. 


\subsubsection{Suchszenario 1}

Das Suchszenario 1 wird als sehr einfaches Szenario konzipiert, bei dem die grundsätzliche Leistungsfähigkeit der Hunde nachgewiesen werden soll (Tagesform des Hundes). Das Gelände ist leicht hügelig mit abschüssig stehenden Bäumen und Büschen unten links und gerade Bepflanzung im oberen Teil des Bildes. Die nebenstehende Abbildung zeigt die verschiedenen Orte des befallenen Holzstücks ohne Larve aber mit Bohrspänen in den Gängen.

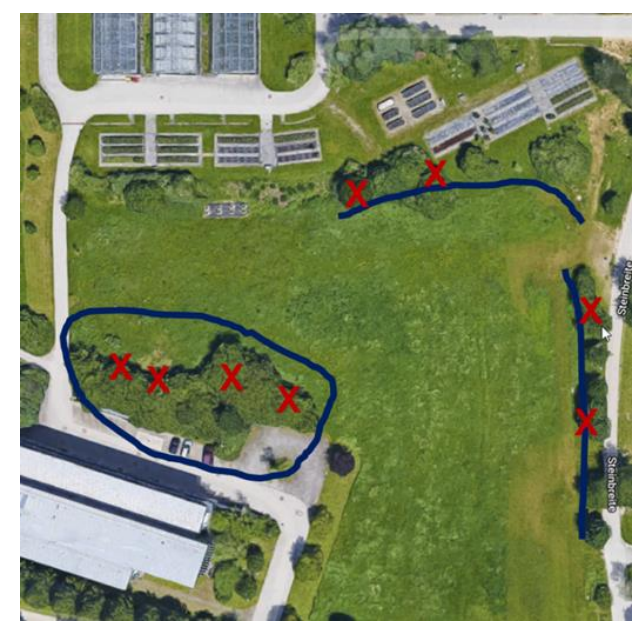

Figure 16: Suchszenario 1, wobei das rote $\mathrm{x}$ die verschiedenen Auslageorte des ALB befallenen Holzstückes markiert.

Bei diesem Versuch wird die Lage des Suchziels von Hundeteam zu Hundeteam variiert, um zu gewährleisten, dass der Hund tatsächlich nach ALB Geruch sucht und nicht durch die Suche von anderen Hunden anzeigt. Als Verleitungen wurden zwei frisch gespaltene, gesunde Laubholzstücke und diverse andere befallsfreie, auffällige Holzstücke verlegt. An dieser Stelle sei angemerkt, dass die Ergebnisse sich dabei auf verschiedene Suchszenarien mit ggf. unterschiedlichen Schwierigkeitsgraden beziehen. Es wird bei der Platzierung der Suchziele aber darauf geachtet, dass die verwendeten Holzstücke in ähnlicher Weise visuell sichtbar sind und dass das Suchziel in ähnlicher Positionierung in Bäumen und Büschen am Boden oder in wenigen Zentimetern Höhe angebracht werden. 


\subsubsection{Suchszenario 2}

Das Suchszenario 2 (Figure 17) beschreibt ein schwieriges Szenario, bei dem Geruchsquelle als Punktquelle in einem unwegsamen und relativ steilen Gelände platziert wurde. Die Probe wurde oben am Hang platziert, der Zugang und Abgang zum Suchgebiet erfolgte von unten, auf dem Bild von links oben in das Baum/Strauchgebiet hinein. Das Szenario ist diesmal für alle Hundeführer gleich, eine Veränderung der Platzierung der Probe ist hier nicht möglich.

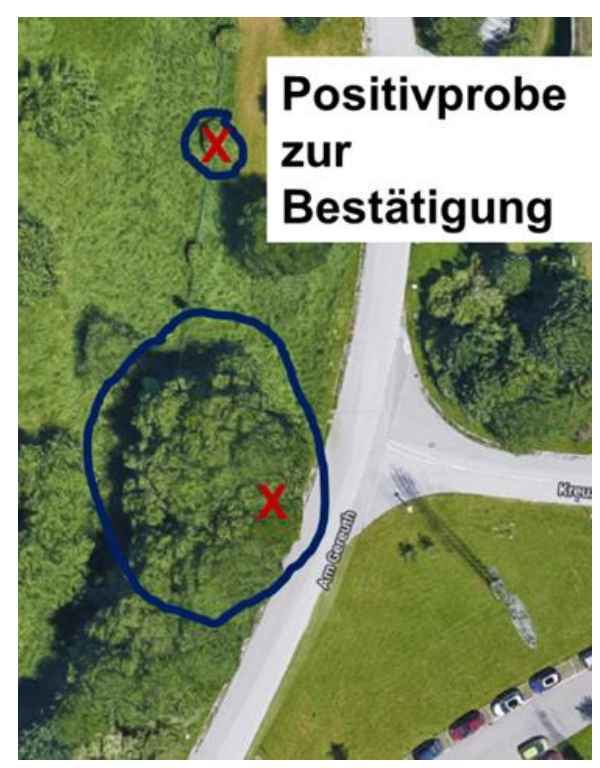

Figure 17: Suchszenario 2, wobei das untere rote $x$, die Lage des unbekannten ALB befallenen Holzstückes markiert und das obere eine bekannte ALB Probe zur positiven Bestätigung der Hunde nach Bedarf

Um dem Hund die Möglichkeit einer positiven Bestätigung der Suche geben zu können, wird in ausreichender Entfernung eine Positivprobe platziert, wobei die Lage der Probe den Hundeführern bekannt ist.

Als Geruchträger werden Träger verwendet, auf denen der Geruch von ALB Lebendlarven gespeichert wurde. Hierzu wird der Geruch von ALB-befallenen Bäumen auf die Träger geleitet, die diesen Geruch speichern und über kleine Öffnungen am Ende der Röhrchen langsam wieder abgeben können. Die Probennahme am Baum und von einer Larve ist in der nachfolgenden Abbildung im linken und rechten Bild gezeigt, der verwendete Geruchsträger ist im mittleren Bild dargestellt.
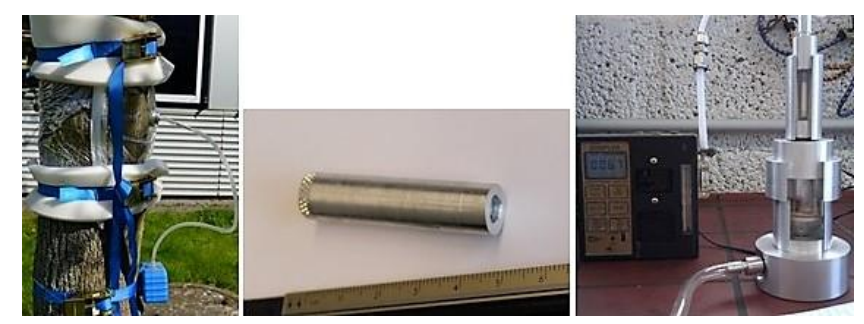

Figure 18: Geruchsträger (Mitte) und zwei Anreicherungsverfahren für die Geruchsträger: vom befallenen Baum (links) und von einer Larve (rechts) 
Die Einsetzbarkeit dieser Geruchträger wurde in Vorversuchen mit Spürhunden auf ihre Eignung hin als ALB Geruchquelle getestet. Im Rahmen der Anreicherungen wurden die Geruchträger auch in den Laboratorien der Hochschule untersucht. So kann sichergestellt werden, dass die Röhrchen mit ALB Geruch angereichert sind. Die volatilen Markerstoffe von adulten Käfern, Larven und Eiablagen sind aus Forschungsarbeiten heraus der H-BRS bekannt und konnten mit instrumentell analytischen Methoden (Thermodesorption/Gaschromatographie-Massenspektrometrie) nachgewiesen werden. Der Nachweis im Labor ist dabei ein wichtiger Schritt des qualitätsgesicherten Nachweises der Verwendbarkeit dieser Geruchträger. Als Verleitungen wurden zwei duftfreie Geruchsträger nicht sichtbar im Suchgelände platziert.

\subsubsection{Suchszenario 3}

Das Suchszenario 3 wird als mittelschweres Szenario konzipiert. Zwei Geruchträger wie in Szenario 2 beschrieben werden auf einem leicht zugänglichen Wiesengelände einmal in einem Baum in $2 \mathrm{~m}$ Höhe und einmal unterhalb einer Rinde in einem Baum auf Nasenhöhe der Hunde platziert. Verleitungen mit frei sichtbaren Röhrchen wurden an Bäumen und Büchschen platziert.

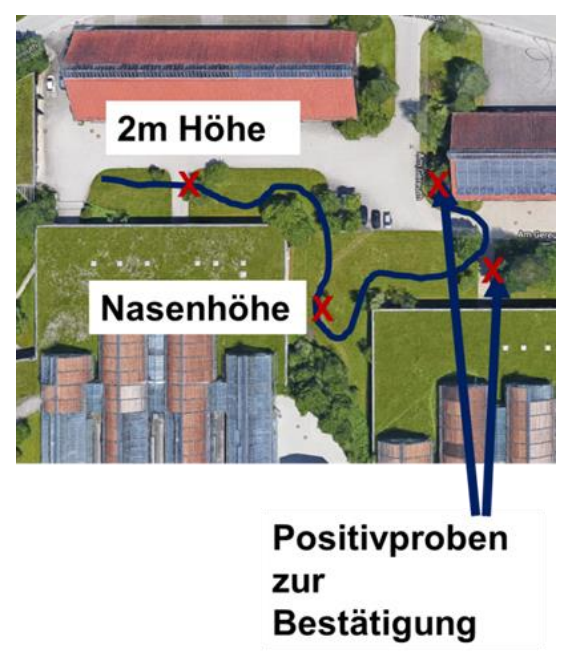

Figure 19: Suchszenario 3 mit insgesamt 3 ALB Proben (2 unbekannte und eine zur positiven Bestätigung nach Bedarf)

Auch in diesem Szenario werden zwei Holzproben zur abschließenden Positivbestätigung der Hunde in ausreichender Entfernung platziert. Die Suche ist für alle Hundeteams gleich. Beginn der Suche ist die auf dem Bild gezeigte linke Seite.

\subsubsection{Suchszenario 4}

Das Suchszenario 4 wird abschließend als sehr einfaches Szenario durchgeführt. Verlegt wurde eine Geruchsquelle mit künstlichem ALB Geruch auf einer kleinen, ebenen Wiese vor einem Gebäude. Das Szenario ist für alle Hundeführer gleich. Die Geruchsquelle wird nicht sichtbar im Rasen auf dem Boden versteckt. 


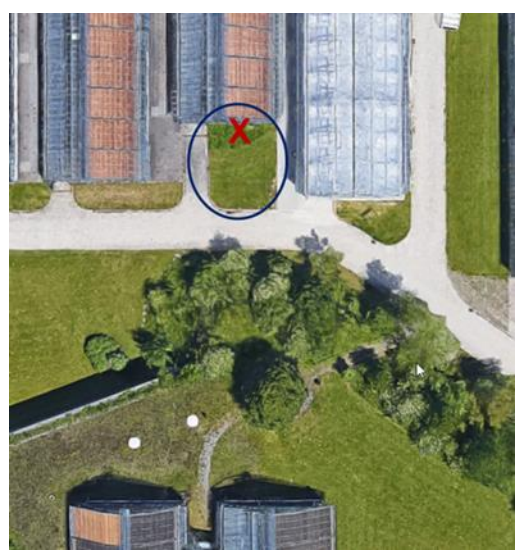

Figure 20: Suchszenario 4 mit synthetischer ALB Geruchsmischung

Als Geruchsquelle wird wie vorab beschrieben der von der Hochschule entwickelte Geruchsträger verwendet. Statt der Anreicherung mit ALB Geruch in einem Quarantäneraum wird hier eine Geruchsmischung verwendet, die typische volatile Komponenten des ALB enthält, die aus eigenen Forschungsarbeiten als spezifische Marker des ALB identifiziert werden konnten. Die synthetischen Geruchsmischungen konnten in Vorversuchen bereits ausreichen getestet werden. Bei dieser Geruchsmischung erfolgt sowohl eine positive Anzeige von auf ALB langzeitkonditionierten Spürhunden als auch von geruchsdifferenzierend ausgebildeten Hunden, die mit der Geruchseingabe der synthetischen Mischung eine positive Anzeige von ALB Material zeigen. Dieses Szenario zeigt von allen Versuchen die beste Auffindrate aller Hundeteams.

\subsection{FAZIT ZU DEN ERSTEN Versuchen EINES QUALIFIKATIONSNACHWEISES FüR}

\section{ALB-SPÜRHUNDE}

Die gezeigten Ergebnisse zeigen, dass die Leistungsfähigkeit der Spürhunde in den verschiedenen Szenarien sehr unterschiedlich ist. Über die Gründe soll an dieser Stelle nicht spekuliert werden, dies war auch nicht Ziel der Untersuchungen.

Gemäß den durch die LfL formulierten Anforderungen lassen sich an dieser Stelle als Fazit nur Empfehlungen aussprechen, wie zukünftig die ALB Suche und das zugehörige Training verbessert werden können.

\section{ALB Stadien}

Um eine eindeutige Positivanzeige lebender und toter ALB-Stadien (Ei, Larve, Käfer) sowie eine Detektion bei fehlenden lebenden ALB-Stadien gewährleisten zu können, bedarf es neben der Ausbildung des langzeitkonditionierten Spürhundes im Wesentlichen dem Zugang zu geeigneten Geruchsquellen, da Lebendmaterial aufgrund der mangelnden Verfügbarkeit und der Quarantänevorschriften für Training und Ausbildung nicht verwendet werden darf. Für diese Geruchsquellen bedarf es

- eines „sauberen“ Geruchs: ALB-Gerüche müssen dominant verfügbar sein. 
- eines „verleiteten“ Geruchs: ALB-Geruch inklusive Fremdgerüche, die typisch für die Suchumgebungen sind (Eiablagen auf und Larven in verschiedenen Baumarten).

Dies gilt sowohl für das Training als auch die Qualifizierungen der Spürhunde.

\section{Geruchsquellen}

Der qualitative und quantitative Nachweis von Reinheit und Stärke der Geruchsquelle für den ALB typischen Geruch als auch für Fremdgerüche ist durch begleitende analytische Messungen erforderlich. Trainingsmaterial, welches über Jahre verwendet wird, ändert seinen Geruch und es kann zur Fehlkonditionierung der Hunde kommen.

\section{Suchumgebungen}

Training und Qualifizierungen sollten in typischen Suchumgebungen stattfinden (Freilandsuche, Palettensuche, Baumschulen etc.), in denen der Hund später vorzugsweise eingesetzt wird. Auch die Schwierigkeitsgrade sollten ähnlich gelagert sein, da der Hund sein Suchverhalten den Suchszenarien anpassen wird.

\section{Qualifikationsnachweis}

Zur Forderung eines regelmäßig aktualisierten Qualifikationsnachweises über die Leistungsfähigkeit des Spürhundeteams in verschiedenen Suchszenarien lassen sich die folgenden Empfehlungen festhalten:

- Qualifizierungen sollten durch unabhängige Einrichtungen vorgenommen werden (Vermeidung des Nachbaus von Trainingsszenarien), eine Unterstützung durch Bedarfsträger (Pflanzenschutzdienste) zur Beschreibung der Suchszenarien ist dabei sinnvoll.

- Qualifizierungen mit angepassten Suchszenarien (Freiland ungleich Container) geben die beste Auskunft über den Qualifizierungsstand des Hundeteams und damit auch über die Anpassung von zukünftigem Training.

- Möglichst Durchführung der Qualifizierungen als "double-blind”, mindestens jedoch "singleblind" damit der Einfluss des Hundeführers auf den Hund möglichst gering ist (kein Reindrücken in die Probe).

- Das Gelände zur Durchführung der Qualifizierungen sollte den Aufbau von mehreren Suchstrecken und verschiedenen Schwierigkeitsgraden ermöglichen (Vermeidung Lerneffekte Hundeteam und Langeweile, Teststrecken können zu keinen Ergebnissen führen z.B. durch Änderungen von Umgebungsbedingungen, Kontaminationen etc.)

- Der Aufbau der Teststrecken sollte mit ausreichend Vorlauf geschehen, Proben die länger lagern bewirken wie in realen Szenarien bei befallenen Bäumen Anreicherungseffekte des Geruchs in der Umgebung, was die Punktsuche für die Hunde vereinfacht. Hier ist jedoch wieder zu beachten, 
dass dies mit einem Vorlauf von ein oder zwei Tagen in nicht bewachten Gelände mit ALB-Material aufgrund der Quarantänevorschriften nicht oder nur bedingt möglich ist.

\section{Allgemeine Anmerkungen zum Qualifikationsnachweis}

Abschließend seien hier noch einige allgemeine Anmerkungen zu den Qualifikationsnachweisen genannt:

- Für die Vorbereitung und Durchführung der Qualifikation ist ein hoher Zeit- und Personalaufwand notwendig.

- Ein Personenwechsel bei Verlegung der Positivproben und Verleitungen ist sinnvoll. Während der Versuche in Freising konnte beobachtet werden, dass nach einiger Zeit die Hunde an versteckten Verleitungen angezeigt haben, vermutlich, weil sie irgendwann nach dem Geruch der Person gesucht haben, die die Objekte versteckt haben.

- Sinnvoll sind ausreichend vorbereitete Versuchsstrecken, die vor den Qualifikationsversuchen präpariert wurden. Dies spart viel Zeit, da diese Aktivitäten erfahrungsgemäß lange dauern. Hier kommt wieder die Problematik zum Tragen, dass dies mit ALB-Material in der Regel nicht möglich ist. Ein Vorabtest der Versuchsstrecken mit bekannten und qualifiziertem Hund, der nicht an den Qualifizierungsversuchen teilnimmt, ist sinnvoll. Somit kann sichergestellt werden, dass die Probe auffindbar ist und dass der Einfluss von Umgebungsbedingungen (Fremdgerüche, Ablenkungen, etc.) nicht zu unnötigen Schwierigkeiten führt.

- Das Gelände für die Testläufe und den Aufbau der Versuchsstrecken sollte ausreichend groß sein. Wichtig ist auch ein regelmäßiger Wechsel des Geländes, auf dem typische Szenarien abgebildet werden können, um keine Verfälschungen durch (optische) Wiedererkennung zu bekommen.

- Eine Qualitätssicherung der Trainingshilfsmittel/Positivproben sollte unbedingt stattfinden, um sicherzustellen, dass die ALB-Positivproben in etwa dem Geruch von ALB-Befällen entsprechen. Aus Sicht der Hochschule können auch die synthetischen Geruchsproben verwendet werden.

- Vermeidung von Prüfungsstress beim Hundeteam. Erfahrungsgemäß ist die Suchleistung bei einem gestressten Team deutlich schlechter als bei einer normalen Suche. Qualifizierungsversuche sollen dem Hundeführer eine Rückmeldung über den Leistungsstand des Teams geben, um Trainingsmethoden verbessern zu können.

- Lange Pausen während der Versuche sollten bei den Hundeteams vermieden werden. Diese führen zu Unlust und schlechten Suchergebnissen. Erfahrungsgemäß sind die Suchleistungen am Nachmittag deutlich schlechter, wenn das Team die meiste Zeit mit Warten verbracht hat. Dies hat zur Konsequenz, dass die Zahl der Hunde, die gesichtet werden sollen, pro Versuchstag nicht zu groß sein soll. 
- Eine unmittelbare Rückmeldung durch einen erfahrenen Hundeführer oder Hundetrainer, der bei der Sichtung anwesend ist, ist sinnvoll. Auf diese Weise können Fehler oder Hinweise zur Verbesserung der Suche direkt kommuniziert werden.

- Es sind die Kosten für solche Maßnahmen zu beachten. Es ist ausreichend geschultes Personal zur Durchführung und Vorbereitung der Qualifizierungsversuche bereitzuhalten und es sind qualitätsgesicherte Geruchproben zur Durchführung von solchen Qualifizierungen notwendig.

\subsection{DANKSAgUng}

Die hier zusammengetragenen Erkenntnisse beruhen auf jahrelanger Arbeit im Labor und mit Hundeteams, die die Hochschule unterstützt haben. Der Dank der Hochschule geht dabei an die Landwirtschaftskammer Nordrhein-Westfalen für die Bereitstellung eines Quarantäneraums, die Pflanzenschutzdienste in Bayern, Baden-Württemberg und Hamburg für die Unterstützung der Arbeiten, das Ministerium für Klimaschutz, Umwelt, Landwirtschaft, Natur- und Verbraucherschutz NRW für die Förderung der wissenschaftlichen Arbeiten zur Identifizierung des ALB-Befalls durch spezifische volatile Substanzen sowie die vielen privaten ALB-Hundeteams für die praktische Umsetzung von vielen Versuchen im Feld.

\section{Authors' contribution}

Im Kapitel 4.2 „Einleitung” formuliert Frank Nüßer vom Landesamt für Landesamt Bayern das Unterkapitel "Aufgaben des Pflanzenschutzdienstes in Bayern". Er unterstützt zudem die Versuche vor Ort und die Koordination und Planung seitens der Hundeführer, die dem LfL angehören.

Peter Kaul verfasst die Kapitel 4.3 "Qualifizierung" und 4.4 „Fazit", darüber hinaus verfasst er gemeinsam mit Ramona Makarow die Kapitel 4.3.1-4.3.5, die die verschiedenen Suchszenarien beschreiben. Peter Kaul unterstütze die Durchführung der Versuche vor Ort mit dem Auslegen der ALB Proben und der Koordination der Hundeführerteams vor Ort.

Ramona Makarow verfasst im Kapitel 4.2 „Einleitung” die Grundlagen und den Stand der Technik zum Thema. Gemeinsam mit Peter Kaul verfasst sie die Kapitel 4.3.1-4.3.5, die die verschiedenen Suchszenarien beschreiben. Ramona Makarow übernahm die vollständige konzeptionelle Vorarbeit zur Durchführung und Planung der Versuche. Die präparierte die Proben, die während der Versuche zum Einsatz kommen. Sie entwickelte das Trägermedium und die synthetischen ALB-Geruchsmischung, die bei den Versuchen zum Einsatz kommt. Während der Durchführung koordinierte sie die Versuche, traf die Auswahl von geeigneten Suchszenarien und übernahm die Dokumentation in schriftlicher Form und in Form von Videoaufzeichnungen. 


\subsection{LITERATUR}

Davis, Mark A. (2009): Invasion Biology. 1. Aufl.: Oxford University Press.

Europäische Kommission (2015): DURCHFÜHRUNGSBESCHLUSS (EU) 2015/ 893 DER KOMMISSION. - über Maßnahmen zum Schutz der Union gegen die Einschleppung und Ausbreitung von Anoplophora glabripennis (Motschulsky). (Bekanntgegeben unter Aktenzeichen C(2015) 3772). Europäische Kommission. Scheibner, Cornelia; Roth, Mechthild; Nehring, Stefan; Schmiedel, Doreen; Wilhelm, Eckehard-G.; Winter, Susanne (Hg.) (2015): Management-Handbuch zum Umgang mit gebietsfremden Arten in Deutschland. Band 2: Wirbellose Tiere und Wirbeltiere. Bundesamt für Naturschutz. 2 Bände. Münster: BfNSchriftenvertrieb im Landwirtschaftsverlag GmbH (Naturschutz und biologische Vielfalt, 141(2)).

Schröder, Thomas (2014): Anoplophora glabripennis. Asiatischer Laubholzbockkäfer. Julius-Kühn-Institut.

Wermelinger, Beat; Forster, Beat; Hölling, Doris; Plüss, Therese; Raemy, Otto; Klay, Alfred (2013): Asiatischer Laubholzbockkäfer und Chinesischer Laubholzbockkäfer. Eidg. Forschungsanstalt WSL. Online verfügbar unter

https://www.waldwissen.net/waldwirtschaft/schaden/invasive/wsl_merkblatt_laubholzbock/index_DE, zuletzt geprüft am 07.12.2019. 


\section{Discussion}

\subsection{SUMMARY OF RESULTS}

It has been shown that airborne volatile organic compounds of a biological sample like Anoplophora glabripennis are traceable in the development stages of larva, imago and oviposition as well as in infested trees when using an adapted analytical method like TD-GC/MS. Based on the analysis of the VOCs emitted by ALB samples (larva, imago, oviposition and infested Acer) and not infested references, (Acer, Salix, Populus and mechanically stressed Acer) some VOCs were determined to be relevant for ALB.

\section{Development of the analytical method}

For the application of identifying VOCs from ALB, standard sorbent tubes packed with Tenax TA® or Tenax GR® showed the best results. Optimised sampling parameters were a flow rate of $30 \mathrm{ml} / \mathrm{min}$ and an enrichment duration of $90 \mathrm{~min}$. An extension of enrichment duration up to $120 \mathrm{~min}$ is possible without breakthrough when using the standard sorbent tubes. But as time is a relevant factor, especially because repeated measurements are recommended, and only an increase in peak area and peak height of already qualified substances was observed, 90 min was found as the optimal enrichment duration for the sampling. The sampling method for standard sampling tubes packed with either Tenax TA® or Tenax GR® was used for the analysis of ALB samples larvae, imagines and ovipositions (see Part I). All together 229 VOCs were detected.

\section{$\underline{\text { ALB Samples }}$}

Regarding the oviposition analysis, measurements of two independent generations each repeated in one to two week delays were carried out with a focus on reproducibility of BVOCs and changes of VOC pattern. Altogether 86 oviposition measurements were carried out. With regards to biologic variance it is notable that the sesquiterpene longipinene occurred in $100 \%$ and the sesquiterpenes cyclosativene and a-cubebene in $99 \%$ of all 86 oviposition measurements. Together with camphene (97\%) and caryophyllene ( $83 \%)$, five sesquiterpenes are detectable in more than $80 \%$ of all oviposition measurements. The substances Z,Z,Z-1,5,9,9-tetramethyl-cycloundecatriene and the monoterpene ocimene only occurred after 4 and 5 weeks after oviposition, respectively.

For the analysis of ALB larvae and imagines 34 and 19 substances were detected. 2,4-Dimethyl-1-heptene and cyclosativene were emitted by all three sample types, whereas 2,4-dimethyl-1-heptene only occurs in the first two weeks after oviposition. To sum it up, the most relevant ALB substances with regards to specificity were (+)- $\alpha$-longipinene, (+)-cyclosativene, copaene/ $\alpha$-cubebene, 2,4-dimethyl-1-heptene and 3-carene. In Table 18 all substances, that occur in at least $50 \%$ of one ALB sample type are concluded. 
Table 18: Overview of the most relevant VOCs emitted by different ALB sample types (ST: sesquiterpene, HC: hydrocarbons, MT: monoterpenes). The numbers indicate the occurrence of the substance in each sample batch in percentage

\begin{tabular}{lllcccc}
\hline \hline Class & CAS & Substance & Infested tree & Oviposition & Larva & Beetle \\
\hline ST & $022469-52-9$ & $(+)$-Cyclosativene & 60 & 99 & 91 & 23 \\
ST & $5989-08-02$ & $(+)-\alpha$-Longipinene & 26 & 100 & 14 & - \\
& $3856-25-5 /$ & & & & 77 & 31 \\
ST & $17699-14-8$ & Copaene/ $\alpha$-Cubebene & 44 & 99 & - & 62 \\
ST & $87-44-5$ & Caryophyllene & 9 & 83 & 59 & 69 \\
HC & $19549-87-2$ & 2,4-Dimethyl-1-heptene & 37 & 6 & 95 & - \\
MT & $138-86-3$ & Limonene & & 32 & 32 & 100 \\
MT & $7785-70-8$ & 1R- $\alpha$-Pinene & 49 & 17 & - & 54 \\
MT & $13466-78-9$ & 3-Carene & 16 & 22 & - & - \\
MT & $79-92-5$ & Camphene & 28 & 97 & \\
\hline \hline
\end{tabular}

\section{$\underline{\text { Native Species }}$}

The analysis of the native insect species Zeuzera pyrina, Saperda carcharias, Cossus cossus and Aromia moschata showed a 7 \% occurrence of 2,4-dimethyl-1-heptene in Cossus cossus larva and Saperda Carcharias pupa. Altogether three sesquiterpenes were identified among native insects: (+)-longifolene, caryophyllene and $\alpha$-farnesene, all of them in Aromia moschata samples (imago and larva) with an occurrence of $39 \%, 17 \%$ and $17 \%$ among all 23 Aromia measurements, respectively (see Table 17). The monoterpene (+)-4-carene was detectable in all seven Aromia moschata imago measurements and the only monoterpene among native insects' VOCs. That means there was no overlap from ALB and native insect species' emitted mono- and sesquiterpenes.

\section{Open Land Detection}

Concerning the detection of ALB in open land, the determination of VOCs directly from an infested tree is of special interest. Therefore, the VOC pattern of ALB infested trees and typical ALB host plants without infestation must be considered. Hence, the analysis of ALB infested Acers were carried out as well as healthy Acer, Populus and Salix in open land (assuming that open land conditions offer the least stress to the trees). But as an ALB-infestation causes stress to the tree, a difference in pattern to healthy trees could also arise from stress. In order to exclude stress as a reason, the analysis of a not infested but differently stressed Acer (cut main branches, greenhouse conditions, poor illumination) was carried out as well. As introduced in chapter 3.2 the emission of VOC is dependent, among others, on the level of stress a tree undergoes.

First of all, it should be pointed to the tremendous influence of environmental influence on the VOC emission: the analysis of three different trees, all of type Acer (Acer I-III), in 5 to 9 repetitions clearly shows the influence of environmental parameters, as for Acer I and Acer II exclusively Isopropyl alcohol was detectable in 2 of 8 and 3 of 9 measurements, respectively. But for Acer III ( 5 time repetition), 27 different substances were detectable with a good reproducibility for all 5 repetitions of measurements (see Table 16 in Supplemental Materials, chapter 3.8). Among the 27 substances, with (+)-longifolene, one sesquiterpene was detectable. 
With Salix, Acer and Populus, 3 of ALB's host trees were analysed under healthy, open land conditions. Altogether 7 sesquiterpenes were detectable: copaene, caryophyllene, trans- $\alpha$-bergamotene, $\alpha$-guaiene, (+)-cyclosativene, (+)- $\alpha$-longipinene and (-)-alloaromadendrene (see also Appendix, chapter 3.8). $89 \%$ of all sesquiterpene occurrences originate from Salix. Especially the Salix emission of copaene, (+)cyclosativene, (+)- $\alpha$-longipinene and caryophyllene offer the potential of misinterpretation, as they also originate from ALB samples. The analysis of ALB infested Acer result in 73 identified substances, of which 23 substances occur in more than $20 \%$ of all measurements. Among them the 3 sesquiterpenes copaene, (+)-cyclosativene and (+)- $\alpha$-longipinene, which also occur from healthy Salix.

\section{$\underline{\text { VOC pattern from Anoplophora glabripennis }}$}

To sum up, during all ALB sample analysis, the relevance of the sesquiterpenes copaene, (+)-cyclosativene and $(+)$ - $\alpha$-longipinene became clear. The combination of these three is present when analysing the VOCs of ALB infested trees, ALB ovipositions on Acer, ALB larva and healthy Salix in open land. Two of them $((+)$-cyclosativene and copaene) are present when analysing ALB beetles and copaene is rarely detectable from healthy Populus in open land. With regards to Salix, a 3-substance combination does not lead to an ALB-distinct result. But a substance pattern of $(+)$-cyclosativene, copaene, $(+)-\alpha$-longipinene and $\alpha$-guaiene is typical for Salix and presence of $\alpha$-guaiene was not detectable for ALB sources. The pattern of ALB could be extended to (+)-cyclosativene, copaene, (+)- $\alpha$-longipinene and 2,4-dimethyl-1-heptene and the monoterpene 3-carene, two substances that do not originate from Salix. Thereby an ALB distinction via VOC pattern is possible.

\section{Application of the results}

The most important application for these results is the development of a detection technique for an early state detection of Anoplophora glabripennis and to avoid the spreading and the damage of trees. For the ALB detection via instrumental analysis or a well-trained technical detector, the knowledge of the ALB VOC pattern is sufficient. But for a biosensor it is still unclear if these selected 'least common denominator' leads to a scent impression that is typical for ALB samples, although differing from the VOC pattern of native species, healthy and stressed trees. This is especially relevant when working with sniffer dogs as ALB detectors. The response or sensitivity of single substances on the sniffer dogs' receptors cannot be calculated or estimated due to their chemical structure. The reasons for substance specific selectivity is most likely to be found in the evolutionary biology and thereby the adaption on abilities due to survival relevance (Legrum 2011).

To clarify the recognition of this substance combination as ALB origin, experiments with differently trained sniffer dogs were realised. A synthetic ALB scent a mixture of (+)-cyclosativene, (+)- $\alpha$-longipinene, caryophyllene and ocimene was prepared from chemical standards. Copaene was not available on the market and no company was found to synthesise the substance. Ocimene was added as a monoterpene that arose when ovipositions were a few weeks old. The ocimene standard consisted of a mix of enantiomers. 
Two groups of differently trained dogs with 5 and 4 dogs, were involved for the experiments. The first group contained 5 sniffer dogs and were commonly known long-term conditioned sniffer dogs. That means, from puppy age onwards the dogs were exposed to ALB samples and a connection to reward and thereby a positive feeling was conditioned. That leads to an activation of the reward system when this scent is recognised by the dog. The synthetic mixture was offered as target to these dogs in a test environment adapted to their usual search behaviour. All 5 sniffer dogs indicated when the mixture of terpenes was offered. Thus, it can be suggested that the scent impression is comparable to real biologic ALB samples. Furthermore, the single mixture substances were offered in the same setting to the sniffer dogs. According to the dog handlers there was a certain interest of the dogs visible but no indication.

The other group of sniffer dogs were scent discriminating dogs. These dogs are used to work according to their short-term memory. In practice, the target substance is given to the dog's nose right before the search. While searching the dog discriminates between the target substance and background. For instance, this kind of conditioning is used for mantrailing dogs. We offered the dogs the synthetic mixture right before the search as target substance and put a living ALB larva in the test environment. All dogs indicated immediately and clearly on the ALB larva. Thus, it can be assumed that these substances are not only specific but also act as indicator substances for the scent impression in case of sniffer dogs.

For the experiments with the sniffer dogs a new adsorption tube (see Figure 18, chapter 4.3.3) bigger in diameter and built of stainless steel was developed. It was used as scent carrier for the sniffer dogs. Due to the desorption of the chemicals on the adsorption material inside, a more consistent and less concentrated source of scent was offered to the sniffer dogs than working with the liquid mixture. It fits into a common $20 \mathrm{ml}$ headspace vial and can be analysed with Dynamic Headspace (DHS) for e.g. quality control reasons. Furthermore, it can be used for the sampling of VOCs from infested trees and then either be used for sniffer dogs or DHS-TD-GC/MS analysis. The sampling parameters were than set to a flow rate of $100 \mathrm{~m} / \mathrm{min}$ and an enrichment duration of $60 \mathrm{~min}$. During first measurements in open land infestations, the standard sorbent tube and the newly developed adsorption tube were used, whereas the newly developed tube with a bigger amount of adsorption material showed more sensitivity and selectivity.

\subsection{CONCLUSION}

With the results of this work the ALB specific VOC pattern has been identified and verified with several sniffer dog experiments. It could be shown that it is feasible to specify a pest's VOC emission to a few relevant substances. On the basis of these results, the reliability of sniffer dogs training and use can be improved due to successfully solving two main challenges: the target odour was clarified, and training aids were chemically defined and analytically controlled. The second main benefit is that these training aids do not underlie to any quarantine regulations. Adulteration due to decomposition processes when working with dead biological material can be avoided completely.

Furthermore, the identification of specific VOCs offers the basis of the development of new technical detectors that help to protect our native trees and biodiversity from invasive pests. Reasonable applications 
for ALB detecting systems are directly on suspicious trees, which could make preventive fellings needless, on focal points of import control for the analysis of containers and their cargo and-as mentioned abovefor an advanced and controlled training for sniffer dogs.

The method of extracting specific VOC patterns could be a promising strategy to prevent an aggravation of the invasive species' problem. With the method more invasive alien pests like Agrilus planipennis or the genus Monochamus, the vector of the nematode Bursaphelenchus xylophilus, can be analysed and their specific VOC pattern added to the ALB pattern. For invasive pests of the same species as ALB e.g. Anoplophora chinensis it is likely that the VOC emission is similar with identical specific VOCs. The extraction of specific VOCs from further invasive pests combined with the VOC pattern of Anoplophora would cover relevant and threatening pests from this decay in Europe and Northern America. The development, approval and implementation of suitable detectors for import controls would be the next step to contribute to the protection of Europe's biodiversity and forest habitats on the basis of this results.

Highlights:

- clear distinction to native insects, at least the most mistaken identified according to the plant protection services

- especially the potential of misinterpretation for the Salixes' emission of copaene, (+)-cyclosativene, $(+)-\alpha$-longipinene and caryophyllene should be carefully kept in mind

- five ALB specific substances were identified and used as synthetic ALB-odour

- their potential as indicator substances for sniffer dogs' recognition was shown

\subsection{OUTLOOK}

The analysis of ALB ovipositions with the developed sampling and analysis method showed excellent reproducibility for the sesquiterpenes, which fulfils a major criterion for the development and the reasonable implementation of a detection technique for ALB. Anyway, the availability of substances decreases when the larvae in the tree develop, as the results for infested Acers in comparison to the ovipositions show. A reason for this could be that the larvae move to the inner part of the tree trunk when reaching the third larval stage (Wermelinger et al. 2015). The results of the VOCs emitted by larva demonstrate that $(+)$-cyclosativene, copaene and (+)- $\alpha$-longipinene are still emitted, but not detectable by sampling on the trunk with the analytical approach. When sampling on the trunk of an infested tree, the impairing detection rates can therefore be explained by a change in produced concentration and an insufficient sensitivity when reaching a lower level of concentration. A possible solution could be offered by the use of PTR-ToF (ProtonTransfer Reaction ionization combined with Time-Of-Flight mass spectrometry) as a sensitive analytical instrument for the direct and online analysis of gaseous samples. PTR-ToF is sensitive to a lower ppbv to pptv range (Yuan et al. 2017). Measurements of the real-time emission of VOCs via PTR-MS either using quadrupole or ToF mass analysers were already done for some infested plants (Algarra Alarcon et al. 2015; Brilli et al. 2011; Cellini et al. 2016; Giacomuzzi et al. 2016). Although mass resolution is with up to $8000 \mathrm{~m} / \Delta \mathrm{m}$ (Yuan et al. 2017), very selective, it is not possible to distinguish the isobaric group of 
sesquiterpenes containing at least 8000 substances (Breitmaier 2005). There are a few publications that solve this limitation by coupling a FastGC and thereby reach a 'pseudo'-online analysis limited by the duration of the GC-run (Romano et al. 2014). The mobile character of this technique makes it suitable for the on-site analysis of, for example, trees or larvae as well as for on-site detection in harbours for import controls done by the plant protection services. Depending on the different applications, changing background could potentially disturb the analysis. PTR-ToF offers the blinding out of disturbing background substances by changing the primary ions (for example $\mathrm{NO}^{+}$and $\mathrm{O}_{2}{ }^{+}$with different soft ionisation potential instead of $\mathrm{H}_{3} \mathrm{O}^{+}$) (Materić et al. 2017). Anyway, the use of PTR-ToF for the detection of ALB is only possible when knowing the target substances. The identification of single sesquiterpenes is not possible by using PTR-ToF as there is only little fragmentation and no differences in molecular mass. This work's results offer the basis for the diligent development of an online-method and can thus be a pioneering tool for the fight against the ongoing threat of invasive species.

While planning and performing the sniffer dog trials, the dog handlers benefited from the deliberations from the perspective of odorants properties and contamination paths. The developed scent carrier used for the trials is persistently requested by the dog handler community. Especially the ever-since ongoing use of the synthetic mixture in the ALB sniffer dog's training are evidence for the improvement these results mean for the sniffer dog's work. A commercial accessibility of the training aids should be targeted. For a reasonable and commercial use of these training aids in the future, a study on ageing and preservation of the scent pattern needs to be done first and should be done as it contributes to the improvement of a powerful detector for wide range infestations.

\subsection{References}

Algarra Alarcon, Alberto; Lazazzara, Valentina; Cappellin, Luca; Bianchedi, Pier Luigi; Schuhmacher, Rainer; Wohlfahrt, Georg et al. (2015): Emission of volatile sesquiterpenes and monoterpenes in grapevine genotypes following Plasmopara viticola inoculation in vitro. In: Journal of mass spectrometry : JMS 50 (8), S. 1013-1022. DOI: 10.1002/jms.3615.

Breitmaier, Eberhard (2005): Terpene. Aromen, Düfte, Pharmaka, Pheromone. 2. Aufl. 1 Band. Darmstadt: WILEY-VCH Verlag GmbH \& Co. KGaA.

Brilli, Federico; Ruuskanen, Taina M.; Schnitzhofer, Ralf; Müller, Markus; Breitenlechner, Martin; Bittner, Vinzenz et al. (2011): Detection of plant volatiles after leaf wounding and darkening by proton transfer reaction "time-of-flight" mass spectrometry (PTR-TOF). In: PloS one 6 (5), e20419. DOI: 10.1371/journal.pone.0020419.

Cellini, Antonio; Biondi, Enrico; Buriani, Giampaolo; Farneti, Brian; Rodriguez-Estrada, Maria Teresa; Braschi, Ilaria et al. (2016): Characterization of volatile organic compounds emitted by kiwifruit plants infected with Pseudomonas syringae pv. actinidiae and their effects on host defences. In: Trees 30 (3), S. 795-806. DOI: 10.1007/s00468-015-1321-1. 
Giacomuzzi, Valentino; Cappellin, Luca; Khomenko, Iuliia; Biasioli, Franco; Schütz, Stefan; Tasin, Marco et al. (2016): Emission of Volatile Compounds from Apple Plants Infested with Pandemis heparana Larvae, Antennal Response of Conspecific Adults, and Preliminary Field Trial. In: Journal of chemical ecology 42 (12), S. 1265-1280. DOI: 10.1007/s10886-016-0794-8.

Legrum, Wolfgang (2011): Riechstoffe, zwischen Gestank und Duft. Vorkommen, Eigenschaften und Anwendung von Riechstoffen und deren Gemischen. Wiesbaden: Vieweg+Teubner Verlag / Springer Fachmedien Wiesbaden $\mathrm{GmbH}$ Wiesbaden (Studienbücher Chemie). Online verfügbar unter http://dx.doi.org/10.1007/978-3-8348-8276-9.

Materić, Dušan; Lanza, Matteo; Sulzer, Philipp; Herbig, Jens; Bruhn, Dan; Gauci, Vincent et al. (2017): Selective reagent ion-time of flight-mass spectrometry study of six common monoterpenes. In: International Journal of Mass Spectrometry 421, S. 40-50. DOI: 10.1016/j.ijms.2017.06.003.

Romano, Andrea; Fischer, Lukas; Herbig, Jens; Campbell-Sills, Hugo; Coulon, Joana; Lucas, Patrick et al. (2014): Wine analysis by FastGC proton-transfer reaction-time-of-flight-mass spectrometry. In: International Journal of Mass Spectrometry 369, S. 81-86. DOI: 10.1016/j.ijms.2014.06.006.

Wermelinger, Beat; Forster, Beat; Hölling, Doris; Plüss, Therese; Raemy, Otto; Klay, Alfred (2015): Invasive Laubholz-Bockkäfer aus Asien. Ökologie und Management. Merkblatt für die Praxis. 2. Aufl. Eidg. Forschungsanstalt WSL. Birmensdorf, Schweiz (ISSN 2296-4428).

Yuan, Bin; Koss, Abigail R.; Warneke, Carsten; Coggon, Matthew; Sekimoto, Kanako; Gouw, Joost A. de (2017): Proton-Transfer-Reaction Mass Spectrometry: Applications in Atmospheric Sciences. In: Chemical reviews 117 (21), S. 13187-13229. DOI: 10.1021/acs.chemrev.7b00325. 


\section{Appendix}

\subsection{ACKNOWLEDGEMENT}

In the first place I want to thank my supervisor Peter Kaul, who offered be possibilities and resources for the realisation of my work. I thank him for his inputs and new perspectives and particularly for the freedom in directing my work. For inspiring discussions and the engineering of new measuring equipment, I want to thank my colleagues, especially Stephan Maurer, Christopher Becher and Sara Schäfer.

I want to express my gratitude to Niko Balkenhol, who stepped in as my supervisor at short notice. I am glad for his support and the support from the whole Institute of Forest Zoology and Forest Conservation and its staff. Wolfgang Rohe (HaWK) and his kind and motivating suggestions were certainly no less supportive! I want to thank my supervisors for their support and the chance to realize this work.

In the very first beginning of this work while the whole realization is depending on the support of other authorities to get access to quarantine material, I often hit the wall. The one authority, which constantly helped to break down these walls, was the plant protection service NRW, namely Gerhard Renker and Dr. Rainer Schrage. I often gave thanks to you in the past, I want to do this here again, and I am convinced there will be a lot more situations in the future I will do again.

However, there were some plant protection services and authorities, that constantly supported my work as good as possible. I want to mention the Landesanstalt für Landwirtschaft Sachsen-Anhalt and the Bayrische Landesanstalt für Landwirtschaft, particularly Frank Nüßer, who supported my measurements in Magdeburg, Kehlheim, Murnau and Feldkirchen (Munich). Another reliable source for pest material is the region Lombardy in North Italy. Not only several alien pests feel comfortable there, but also my colleagues and me had a beautiful and successful visits there. Thank you, Alessandro Bianchi for the search and organization of fresh ALB-material. Grazie a te! Grazie a voi!

I want to address a special thanks to Savanna Sewell! She was the patient colleague, who spend hours and days on proofreading of this thesis. As also the most substantiated content is most persuading when written in adequate form of words, I appreciate a lot the accurateness with which she worked through this thesis.

I appreciate a lot a friend, who was sparing-partner for me, who discussed strengths and weaknesses of my work merciless and honest, who heard times of frustration in the tone of my voice and who steps in when things get rough. Who asks the right questions and is there when I need him. Thank you, Kai. 
An erster Stelle danke ich meinem Betreuer Peter Kaul, der mir alle Möglichkeiten und Rahmenbedingungen für die Umsetzung dieser Arbeit schaffte. Ich danke ihm für seine Anregungen und neuen Sichtweisen und insbesondere für den großen Handlungsfreiraum, den ich während meiner Arbeit hatte. Für anregende Gespräche und dem Bau von allerhand Messequipment danke ich meinen Kollegen, hier ganz besonders Stephan Maurer, Christopher Becher und Sara Schäfer.

Ein besonderes Dankeschön, gilt Niko Balkenhol. Er hat ganz kurzfristig und unkompliziert die Erstbetreuung meiner Arbeit übernommen. Ich bin sehr dankbar für diese Unterstützung, die mir aus dem gesamten Institut für Forstzoologie und Waldschutz und seinen Mitarbeitern entgegengebracht wurde. Wolfgang Rohe von der HaWK Göttingen steht den Kollegen mit seiner freundlichen und motivierenden Unterstützung und seinen Denkanstößen in keiner Weise nach! Alles in allem, danke ich meinem Betreuungskonsortium für die anhaltende Unterstützung und die Ermöglichung der Erstellung dieser Arbeit. In den ersten Monaten und sogar Jahren dieser Arbeit, in denen man auf die Unterstützung anderer Behörden angewiesen ist, um an Tier- und Pflanzenmaterial zu kommen, bin ich sehr häufig auf Hürden und Widerstände getroffen. Die eine Stelle, die die Überwindung der Hürden möglich gemacht hat, war der Pflanzenschutzdienst NRW und hier ganz besonders Gerhard Renker und auch Dr. Rainer Schrage. Ich habe mich oft persönlich bedankt, ich will es hier noch einmal tun und ich denke, auch in der Zukunft werde ich noch oft Anlass bekommen mich bei Euch zu bedanken.

Es gab aber auch Pflanzenschutzdienste und Behörden, die mich stets und so gut sie konnten unterstützt haben. Hier möchte ich mich bei den Kollegen von der Landesanstalt für Landwirtschaft Sachsen-Anhalt bedanken, und bei der Bayrischen Landesanstalt für Landwirtschaft, insbesondere bei Frank Nüßer, die mich in Magdeburg, Kehlheim, Murnau und Feldkirchen (München) bei meinen Analysen unterstützt haben. Eine wunderbare Quelle für Quarantänematerial ist auch die Region Lombardei in Norditalien. Nicht nur fühlen sich allerhand invasive Arten dort sehr wohl, auch ich und meine Kollegen wurden dort immer sehr herzliche in Empfang genommen und umsorgt. Vielen Dank an dieser Stelle an Alessandro Bianchi, der uns wann immer wir angefragt haben, Material zusammengesucht und bereitgestellt hat- auch wenn die Kollegen dafür die Bäume erst fällen mussten. Grazie a te! Grazie a voi!

Ein ganz besonders großes Dankeschön will ich Savanna Sewell aussprechen. Sie ist die geduldige Kollegin, die Stunden und Tage mit dem Korrekturlesen dieser Arbeit verbracht hat. Weil auch fundierte Inhalte in korrekter Form und Formulieren am überzeugendsten daherkommen, weiß ich ihre akribische und mühevolle Unterstützung rund um alle Regeln der englischen Grammatik und Rechtschreibung sehr zu schätzen.

Ich bin sehr dankbar für einen sehr guten Freund, einen, der mir Sparring-Partner war und ist, der Stärken meiner Arbeit ebenso wie Schwächen schonungslos und offen mit mir diskutiert, der mir Zeiten der Frustration an meiner Stimme anhörte und einspringt, wenn es schwierig wird. Der immer da ist, wenn ich inn brauche. Der die richtigen Fragen stellt. Danke, Kai. 


\subsection{FinAl deCLARATION}

I, Ramona Makarow, confirm that the work for this dissertation with the title "Investigation of the specific volatile organic compounds emitted by Anoplophora glabripennis (Moschulsky)" was solely undertaken by myself and that no help was provided from other sources as those allowed. All sections of the paper that use quotes or describe an argument or concept developed by another author have been referenced, including all secondary literature used, to show that this material has been adopted to support my thesis. This work has not been presented international or national as thesis before. 